\title{
ELEMENTOS SOCIO JURÍDICOS PARA LA DESCRIPCIÓN DE LA DEMOCRACIA EN COLOMBIA
}

\author{
Presentado por: \\ Camilo Andrés Barajas Villarreal \\ Candidato al Título de Maestro en Derecho Público
}

UNIVERSIDAD SANTO TOMÁS

FACULTAD DE DERECHO

BOGOTÁ

2014 


\title{
ELEMENTOS SOCIO JURÍDICOS PARA LA DESCRIPCIÓN DE LA DEMOCRACIA EN COLOMBIA -CRÍTICA-
}

\author{
Presentado por: \\ Camilo Andrés Barajas Villarreal \\ Candidato al Título de Maestro en Derecho Público
}

Director

Profesor Manuel Salvador Grosso García

UNIVERSIDAD SANTO TOMÁS

FACULTAD DE DERECHO

BOGOTÁ

2014 


\section{CONTENIDO}

$\S$

Introducción. 5

\section{\$1 \\ CAPÍTULO I \\ ANÁLISIS DOGMÁTICO}

1. Articulación de enunciados metodológicos y teóricos para adentrarnos en el estudio

1.1. Manejo de los conceptos aplicados a la investigación 21

1.2. Ideas, teorías o concepciones que ayudarán a describir la democracia

2. Estructura de la democracia 46

2.1. El sub-sistema de la política ..................................48

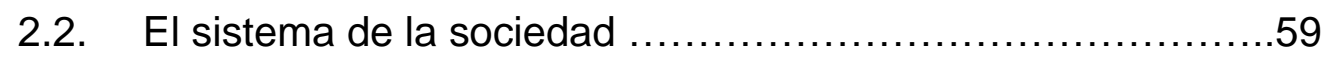

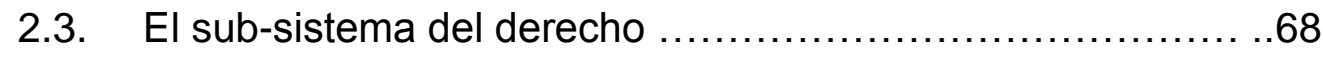

3. La democracia como sub-sistema creado a partir de la interpenetración de los otros sistemas.

3.1. El sub-sistema de la democracia tomando como punto de partida la interpenetración .73

3.2. El desprecio etiquetado como resultado del proceso democrático 79

3.3. El contrato/mandato 86

§2

CAPÍTULO II

PERSPECTIVA DE LA DEMOCRACIA EN COLOMBIA

1. El voto programático en Colombia .97 
1.1. Los problemas políticos del pasado y del momento presente

1.2. Generalidades de la democracia dentro de la Constitución de 1991

1.3. Aspectos legales del voto programático ......................120

2. Jurisprudencia de la Corte Constitucional sobre el voto programático y la revocatoria del mandato 129

2.1. El papel de la Registraduría Nacional del Estado Civil frente a la revocatoria del mandato

3. Caso concreto

3.1. Hacia una lectura no subjetivizada en el caso ................152

3.2. La promesa del gobierno. Mandato a seguir ...................154

3.3. Desarrollo del mandato, problematizaciones y gestión de la revocatoria del mandato 162

3.4. ¿Se llevó a cabo la revocatoria? 171

Conclusiones 176

Bibliografía 184 


\title{
ELEMENTOS SOCIO JURÍDICOS PARA LA DESCRIPCIÓN DE LA DEMOCRACIA EN COLOMBIA
}

\author{
Por: CAMILo ANDRÉs BaRAJAs VILLARREAL
}

\section{INTRODUCCIÓN}

Si pretendemos iniciar un estudio sobre la democracia, tenemos en principio que recordar un sinnúmero de antecedentes propuestos al tema planteado; partiendo desde sus presupuestos hasta su deficiente forma de concebirla, pero al fin de cuenta nos encontramos ante una institución que hoy no revela en nada lo que otrora pudo haber significado a nivel teórico, y por ello volvimos lo anterior un tema para investigar desde diferentes ópticas.

Aunque no desconoceremos los aportes de la filosofía clásica, encontramos en la obra el malestar de la democracia del profesor italiano CARLO GALLI (2013) una descripción de la democracia desde la Grecia antigua hasta la Edad Global, época donde según éste autor nos encontramos. Pero en esa misma descripción el autor advertía defectos en la institución democrática, no tanto históricos como sí en la manera en que se concebía. De ahí que comenzara diciendo que Aristóteles: 
"en el libro IV de la Política (129a-b) [define la democracia] como el gobierno de los libres y de los pobres que, por lo general, constituyen la mayoría, y la distingue de la oligarquía, el gobierno de los ricos y nobles que, por lo general, representan una minoría" (GALLI, 2013, p.16)

Sin embargo, también en Aristóteles se encuentran posturas donde no es la mayoría la que gobierna como una asamblea popular, sino se puede presentar también en las leyes una manera de vivir dentro de la politeia. Pericles por su parte entendió la democracia como un autogobierno entre personas civiles donde se pretendía una armonía entre los poderes públicos y privados. GALLI (2013)

Otra postura distinta se encontraba con Platón, quien en la República entendía la democracia como: "esencialmente un individualismo anárquico y desenfrenado, una carencia de medida y de conocimiento, tanto de uno mismo como de la ciudad (VIII, 555b.563e)" (GALLI, 2013, p.16). Quizá los anteriores planteamientos ayudaron a que entrada la Edad Media se empezará a pensar que dentro de la democracia se vivía en una constante lucha contra diversas formas de poder, entre ellas la tiranía y la oligarquía.

Ahí empieza una bifurcación para explotar los temas propuestos porque en paralelo al establecimiento de las primeras repúblicas medievales, por lo menos en Inglaterra, se empezó a comprender lo político como algo realmente determinante en la manera de organización territorial, y se veía en la 
democracia una serie de falencias que impedían garantizar un orden para el progreso de los primeros Estados.

Como si fuera poco, con la influencia de la iglesia, éstos concebían a partir de la misma estructura organizacional que tenían, una manera de interpretar a los pueblos como aquella gran familia extensa donde su padre era el monarca, de tal suerte la unidad política era considerada un cuerpo vivo y el poder quedaba justificado en manos de un solo individuo. En dicho esquema se pudo comprender la manera en que el hombre común fue alejado de la política y se le inculcó obediencia a lo desconocido como también a las representaciones terrenales de lo místico.

El anterior estado de cosas, fue explorado por el profesor norteamericano Michael WALZeR (2008) quien se ha dedicado al estudio sociológico e histórico de la política en su obra la revolución de los santos, pero específicamente nos expone los orígenes de la política radical cuyos inicios datan de las ideas de Calvino. Ahora bien, en una de sus explicaciones encontramos los argumentos de cómo el individuo en la Edad Media era alejado de la participación política con ideas tales como:

"el cristiano individual tenía un destino fuera del cuerpo político y ese destino era el cielo; pero no había un refugio seguro [de ahí que] (...) la relación entre padre político e hijos políticos podía describirse de manera plausible en 
términos de amor solamente, y en modo alguno como una forma racional y necesaria de subordinación" (WALZER, 2008, p.193 y 198).

Incluso antes, se encuentra una referencia más antigua en la filosofía estoica cuando Epicteto encontró que la política eran esos asuntos que no podían estar en manos de todos, raciocinio al que llego desde su experiencia como esclavo donde relataba: "los hombres se habían convertido, de una manera u otra, en súbditos, cuya existencia política tenía una sola característica inicial: todos ellos obedecían órdenes impersonales, más o menos legales" (WALZER, 2008, p.19).

De esta forma se justificaba cómo la actividad política dirigía los asuntos públicos empero, las necesidades privadas estaban fuera de todo discurso popular con un ingrediente adicional, la obediencia y respeto a las órdenes del rey generaba en aquellas sociedades vínculos de honor hacia su gran padre, incluso podían morir en su nombre dada la lealtad que se juraba tomando como justificación un mandato divino cuya recompensa como se describió unas líneas más arriba se daría en los cielos.

Después de varias guerras civiles y las primeras reformas, los problemas de la monarquía se fueron transformando hacía la mirada de hombres libres, se empezaron a crear ficciones fundadoras del interés general y los primeros mandatos constitucionales especialmente en Inglaterra. La política y administración de la nación empezó a manejarse a partir del criterio de 
legitimidad popular lo cual llevo a un nuevo panorama donde la democracia volvería a surgir.

Y quizá bajo esa misma dinámica de legitimidad, la sociedad llena de necesidades tanto particulares como colectivas, encontró en la alternativa de las elecciones, posibilidades de acceder a contrapartidas o beneficios por reconocer a un político sobre los otros y así avalar la llegada al poder público de un candidato. En una manera un tanto similar, NÉSTOR GARCía CANCLINI (1984) en un artículo titulado Cultura y organización popular, nos permite justificar la anterior proposición cuando sostenía: "si no pensamos al pueblo como una masa sumisa que se deja ilusionar siempre sobre lo que quiere, admitiremos que su dependencia [hacia los políticos] deriva, en parte, de que encuentra en la acción hegemónica cierta utilidad para sus necesidades" (p.6).

Así las cosas, podríamos afirmar la existencia comportamientos de doble beneficio en principio, entre el político y los ciudadanos por un lado y la sociedad hacía el político por otro; pero a la postre se termina convirtiendo en un escenario completamente diferente, donde el candidato ahora dirigente del gobierno termina reificando a la comunidad de electores.

Aun así el ciudadano termina por dejarse guiar en las próximas elecciones por aquel sujeto político el cual, en épocas electorales sale de su esfera política a las calles y advierte las penurias de sus seguidores. Dicha dinámica PIERRE RosanvalLon (2009) la explica partiendo del supuesto de un ciudadano 
indefenso y poseído de necesidades donde encuentra en su mismo espacio un sujeto redentor de su clamor, esto es, deja de lado su participación política como sujeto de cambio y se refugia en un tercero al que le daría eventualmente un mandato, de ahí que:

"La elección obedece, entonces, a un principio de distinción (...) el elector admite de manera implícita que el elegido tiene capacidades que él mismo no posee. Pero simultáneamente se espera del representante que se mantenga cercano a sus electores, que conozca sus problemas y preocupaciones, que comparta sus inquietudes y aspiraciones" (ROSANVALLON 2009, p. 269).

De lo anterior comprendemos por lo menos cuatro asuntos que nos serán útiles para abordar el siguiente ensayo: (I) podemos encontrar la presencia de elementos políticos determinantes, (ii) las necesidades de las personas privadas se han encontrado a lo largo de la historia en la periferia de la gobernabilidad pero son tenidas en cuenta como enlace para la justificación de criterios de legitimación en el poder, (iii) se ha hecho creer que la política per se es algo extraño a la sociedad y, (iv) las leyes han estado presente durante toda la historia tanto para organizar la sociedad como para crear una legitimidad en aquellos que están en el poder y toman las decisiones.

Del anterior estado de cosas encontramos una multiplicidad de contenidos que por la misma descripción anteriormente realizada no pueden ser descartados 
y mucho menos darles un enfoque jurídico aislando lo demás. Para ello, tomaremos prestada la expresión hibridez del profesor NÉSTOR GARCíA CANCLINI (2001) en su obra culturas híbridas, entendida como aquellos "procesos socioculturales en los que estructuras o prácticas discretas, que existían en forma separada, se combinan para generar nuevas estructuras, objetos y prácticas" (p.14), y lo acoplaremos a los temas políticos, sociales y de derecho los cuales tienen que ser necesariamente combinados para estudiar la democracia, y sus tendencias actuales en especial el proceso de electoral.

Así las cosas, expondremos la estructura del Estado como primera manifestación de la política; de la Sociedad como esquema donde juegan todas las operaciones de comunicación entre las instituciones de Derecho Público y los individuos, pero desarrollaremos en dicho apartado las necesidades sociales $y$, finalmente describiremos el Derecho como manifestación de todo el andamiaje jurídico vigente que regula o sanciona operaciones dentro de la sociedad. Realizado lo anterior, y explicadas sus funciones elaboraremos una proyección teórica de cómo es que nace la democracia moderna y cuáles son sus funciones.

En este punto, advertimos hacer una explicación previa a lo que entraremos a estudiar dentro de la sociedad. Y como a nivel teórico ya se estipuló como abordaremos los estudios de Estado y Derecho, en lo referente a lo "Social", variaremos su formulación habida cuenta que no explicaremos los procesos 
sociales y sus ideales; de hacerlo nos saldríamos del eje central de nuestro ensayo.

Más bien lo que entendemos es lo siguiente: para llegar a $<<$ lo social $>>$, previamente la sociedad ha tenido que incurrir en un proceso histórico de lucha por el reconocimiento de sus derechos, sin embargo, lo latente dentro de dicho escenario es que siempre estará presente una $<<$ necesidad $>>$ en sentido expreso y sobre lo cual "el Estado se ha retirado, o está retirándose, de un cierto número de sectores de la vida social que le incumbían y que tenía a cargo" (BOURDIEU 2011, p.180), y justamente a eso que empieza a omitir el Estado lo aprovecha todo el sub-sistema político.

Y lo emplean de la mejor manera, victimizando al ciudadano, haciéndole ver que "sus experiencias adversas no han sido consideradas. En esas condiciones, [el político empieza a], darle existencia social a las historias de las que estos individuos dan testimonio [de su desamparo]" (ROSANVALLON 2009, p. 273). Hasta aquí ya tenemos suficientes elementos para explicarle al lector cómo vamos a abordar el tema de lo "social".

Si bien partiremos de la cláusula normativa del artículo $1^{\circ}$ de la Constitución de 1991, dentro de lo $<<$ social $>>$ examinaremos las $<<$ necesidades sociales $>>$ y su dinámica dentro de la democracia en punto de los procesos de elección popular. 
Al terminar esta primera parte tendremos una justificación dogmática y metodológica que nos puede ayudar en lo que sigue, esto es, comprender la normatividad de un sistema jurídico como el colombiano, en especial la forma en que las leyes y la misma jurisprudencia entienden la Democracia a partir de los mecanismos de participación ciudadana, particularmente el voto programático y la revocatoria del mandato.

Finalmente concluiremos si nuestro aporte teórico, en lo que tiene que ver con la formulación de la democracia como sub-sistema, se pudo contrastar con el estudio del caso concreto, si nuestra hipótesis pudo ser falseada o verificada, y lo más importante, qué críticas en torno a toda la investigación se expusieron como aportes además de la significativa elaboración teórica de lo que podemos entender por democracia.

Ahora bien, como no pretendemos explicar la democracia basada en la tradición racionalista o empírica, procuraremos construir el lenguaje de los conceptos de política, sociedad, derecho y democracia, que permita no tanto una descripción completa, pero sí su mayor acercamiento a lo que hoy se puede entender por éstas. Ello implica ser bastante cauteloso en las pautas a emplear, además porque el mismo diseño de la investigación y los objetivos que se trazaron hacen de éste un proyecto ambicioso en cuanto al contenido de cada temática que se pretende abordar. 
Para afrontar eso, empleamos las enseñanzas del profesor italiano GIOVANNI SARTORI (2010) en lo referente al manejo de los conceptos, pero más específicamente en su denotación. Así las cosas, y como lo pretendido es conferir significado a diferentes enunciados, se usó como fundamento metodológico el análisis de textos filosóficos, sociológicos, de teoría crítica y del derecho, pero con la responsabilidad de acoplarlos a nuestros propósitos y significaran lo que queríamos exponerle al lector, esto es, no tanto una enunciación arbitraria, sino ponerlo en contraste con lo perceptible a los sentidos, o a nuestra experiencia, de esta manera, la función de los conceptos facilitaría la comprensión sin que se confundieran los respectivos enunciados. Aunado a lo anterior, al permitirnos construir las definiciones nos valdremos de ellas mismas para criticar <<la democracia >>.

Al iniciar con el tema de cómo abordar una investigación sobre la democracia fueron más los obstáculos que encontramos para tener un punto de partida, que las bases firmes sobre las cuales sostener proposiciones válidas. El primero de ellos consistió en la forma tradicional en que se describe etimológicamente la palabra democracia; sobre el particular, nos resultó imposible creer que la expresión "el poder del pueblo" fuera válida frente a la realidad percibida. Ello nos llevó a recordar lo que "BERTRAND DE JOUVENEL destac[ó] en 1945 cuando comprendía: «las discusiones sobre la democracia, los argumentos en su pro y en su contra, son intelectualmente inútiles porque no sabemos de qué estamos hablando»" (SARTORI, 2007, p. 25). 
A pesar de las dificultades y omisiones a las que pudo haberse llegado, el objetivo del presente ensayo consistía en reconstruir a partir de nociones teóricas, las tendencias de la actualidad democrática en Colombia quedando por evidente el hecho de habernos apartado de las nociones clásicas de democracia expuestas por Aristóteles o Platón. Y quizá ello va a explicar el encanto de poder justificar lo que consideramos los planteamientos actuales de la democracia en una sociedad cargada de necesidades y problemas.

Así las cosas, se abandonó el concepto uniformemente aceptado de demos kratos porque efectivamente se observa que no es así. Por lo tanto, los conceptos de política, derecho y sociedad no se formularán de manera abstracta comoquiera que serán plausibles o por lo menos identificables por los sentidos, y nos servirán de justificación cuando argumentemos la democracia. Por lo anterior, como primer acierto metodológico y previo a adentrarnos en lo que consideramos es la democracia, explicaremos los elementos nucleares del mismo. Ello nos abrirá la puerta a la discusión de si realmente vivimos en un Estado Democrático o qué hay después de $<<l a$ actualización de las estructuras de poder >>. Para nosotros, la sociedad deja de tener $<<$ el poder en sus manos $>>$ y pasa a ser una simple etiqueta que legitima un orden administrativo dominado por la política.

Lo que habría que entrar a comprender ahora es cómo explicar la forma de abordar cada temática. Para ello fue necesario valernos de los distintos razonamientos teóricos empleados por NIKLAS LUHMANN, y los sistemas 
sociales sin que ello implique abordar toda la complejidad de su extensa obra. Entonces, omitiendo muchos detalles, pretenderemos justificar una nueva forma de explicar el fenómeno democrático bajo la premisa que dicho concepto tan comúnmente aceptado teóricamente no se justifica a la realidad.

Ahora bien, como es un hecho que la democracia se vale de otros saberes establecidos al interior de la sociedad, consideramos oportuno explicarlos y delimitarlos entre sí sin que a su vez pierdan su particularidad o identificación que les sea propia quedando de esta manera ajustado a las exigencias metodológicas el por qué nos referiremos a la política, sociedad y derecho antes de entrar a definir la democracia como tal, pero lo que sí nos permitirá en este primer nivel es evidenciar que, en efecto, no vivimos en democracia bajo el entendido que exista un interés general que cobija a todos las personas dentro de la sociedad.

Así las cosas, haremos uso de la Teoría de los Sistemas cuando sea necesario, específicamente cuando pretendemos diferenciar un sistema de su entorno y de otros sub-sistemas, bajo el entendido que la misma sociedad como sistema tiene una amplia gama de sub-sistemas y para nuestro proyecto nos valdremos de dos, política y derecho incluyendo la dinámica de la interpenetración para dar explicación a la democracia, toda vez que, desde nuestro punto de vista el tema democrático no es un instituto particular sino que en su interior, como se demostrará juegan entre sí varios conceptos con distintas variables. 
Pero lo importante también es ajustarnos a un espacio temporal dentro de la órbita colombiana, partiremos desde el enunciado constitucional del artículo primero específicamente en las cláusulas Estado - Sociedad- Derecho desechando el resto de contenidos descritos en dicho enunciado. Descritos entonces los planteamientos generales de la manera en que abordaremos la investigación, se hace necesario fijar unas pautas que permitirán tener un rumbo fijo que nos recuerde el motivo principal de la investigación, así como unos parámetros de medición que justifiquen y ayuden a ensamblar todo el contenido.

Así las cosas, como objetivo general se planeó una explicación de la democracia, entendida como un sub-sistema que únicamente surge cuando se van a actualizar las estructuras de poder en las instituciones de Derecho Público a las que se llega por elección popular. En lo referente a los objetivos específicos pretendimos: ( $I$ ) describir los enunciados que definen la democracia en Colombia, (ii) elaborar la estructura de la Democracia, (iii) explicar la democracia como sub-sistema creado a partir de la interpenetración de otros sub-sistemas, (iv) desarrollar la perspectiva normativa y jurisprudencial de la democracia en Colombia tomando como referencia el voto programático y la revocatoria del mandato y $(v)$ analizar un caso concreto.

Al enmarcar lo pretendido a investigar, configuramos el siguiente problema de investigación: ¿existe una manera de describir teóricamente la Democracia en 
Colombia a partir de los fenómenos políticos, sociales y jurídicos, tomando como referente la Constitución Política de 1991? Para intentar proyectar una posible solución, fijamos una hipótesis la cual esperábamos pudiera ser verificada o falseada y que la expondríamos así:

La democracia no subsiste por sí misma ni tampoco se vive en democracia dentro de la actual forma de Estado; al parecer, lo que se genera es un discurso empleado cada periodo constitucionalmente estipulado, donde los agentes matriculados indistintamente a los sub-sistemas de la política y del derecho, generan situaciones ex ante que apuntan a los sentidos, las emociones, e incluso las necesidades de las personas del común -Sociedadpara así tener un motivo para ir a las urnas, lo cual nos permite inferir que con dicho ejercicio se crea el sub-sistema de la democracia, por determinado tiempo y durante un espacio breve, lo cual ratifica la legitimidad de la elección de gobernante a partir de los medios democráticos; no obstante, el subsistema de la democracia desaparece bajo el entendido que nuevamente volverá a ser útil en los próximos comicios. 


\section{CAPÍTULO I}

\section{ANÁLISIS DOGMÁTICO}

\section{ARTICULACIÓN DE ENUNCIADOS METODOLÓGICOS Y TEÓRICOS PARA ADENTRARNOS EN EL ESTUDIO}

Pretender un estudio sobre democracia implica hacer una significativa tarea en la búsqueda de un lenguaje y una metodología que no solo intente explicar el fenómeno democrático en una sociedad compleja como la de finales del siglo XX y comienzos del XXI, sino además definir sobre qué bases se está moviendo y cómo lo hace. Por lo tanto, no es viable referirse a los primeros modelos democráticos, bien sean clásicos o post-revolucionarios, de hacerlo existiría una falacia ideológica, como quiera que las realidades cambian de manera constante.

Incluso, más allá de lo pensado, se puede observar que hoy en día el discurso sobre el cual se desarrolla la democracia es otro, por ello, dejaremos de lado la alternativa de investigar la similitud entre sistemas democráticos de otros países occidentales para ayudar a descifrar el nuestro, comoquiera que difícilmente se pueden explicar entre sí, o no se ajustan al intentar compararlos debido a lo problemático que puede ser tomar como referencia cualquier otro Estado donde las realidades varían en todos los niveles. 
Entonces, para que la investigación no pierda rigurosidad tomaremos ideas teóricas de varios autores en diversas áreas del conocimiento, y a partir del dominio de sus temáticas intentaremos argumentar la actual democracia, básicamente a partir de dos premisas:

a) La primera obedece a que "dada la importancia del contexto, el fenómeno, [de] la democracia, no sólo tiene diferentes características según regiones, sino que enfrenta además desafíos cambiantes" (NOHLEN, 2011, p. 72).

b) La segunda, porque democracia entendida como teoría, no consiste en una producción continua como la teoría jurídica o científica, sino que dependerá de fuertes movimientos, bien sea políticos, jurídicos, económicos o de medio ambiente que generen cambios en la sociedad y provoquen la incursión de nuevos conceptos a nivel de la democracia.

Bajo el anterior entendido, se puede afirmar que por lo menos en Colombia desde 1991 la institución de la democracia ha permanecido un tanto estática en cuanto a su definición, y por esta razón se puede realizar una crítica de lo que hoy percibimos, ya que el simple hecho de ejercer el derecho al sufragio cada cuatro años no ejemplifica lo complejo de lo que es el vivir en la democracia toda vez que, a partir de dicha práctica, se distribuye el poder y se genera el cambio de reglas en el Derecho Público en lo que corresponde a la administración de unos recursos y la gobernabilidad de un territorio específico. 
Ahora bien, puede llegar a objetarse la metodología anteriormente trazada, como es la de describir la democracia de los inicios del siglo XXI en Colombia a partir de autores que nada influyeron en los modelos democráticos existentes, pero en realidad consideramos esto una alternativa viable, antianalógica y no dominante al evitar investigar los mismo temas en torno a la democracia, como por ejemplo su importancia, pues no se pretende abordar la investigación con la acostumbrada división del derecho por grupos de interés "para decidir a qué lado de la teoría se pertenece [o] si se parte de una o varias fuentes del derecho" (LUHMANN, 2005, p. 361), sino todo lo contrario, es una opción para realmente considerar algunas características trascendentales y que pueden llegar a demostrar otro estado de cosas, o una nueva función no descrita inmersa en las bases mismas de la democracia o en sus resultados. Aclarado lo anterior, conviene hacer algunas explicaciones teóricas, metodológicas, y conceptuales.

\subsection{MANEJO de LOS CONCEPTOS APLICADOS A LA INVESTIGACIÓN}

Al abordar estudios de la democracia cuyo objeto se encierra en las ciencias sociales por cuanto su análisis pasa por la ciencia política, historia, economía, filosofía, sociología y derecho, se encuentra necesario seguir unos lineamientos metodológicos que, aunque no son rígidos, permiten evitar incurrir en "el abuso de un verbalismo cuantitativo" (SARTORI, 2011, p. 23), donde muchas veces se habla o sostienen proposiciones sin tener la más 
mínima idea de lo que significa y de los efectos que puedan llegar a tener en la comunicación.

Lo anterior es de común referencia no sólo en la comunicación misma que se da entre sujetos -la sociedad-, sino también entre el Derecho y la Política en donde, al parecer, existen diferencias en cuanto a la apreciación o el significado de los conceptos. Sin embargo, pareciera que dentro del imaginario de los significados existiera, independientemente de las nociones que cada uno pueda tener, una relación horizontal-vertical: horizontal en cuanto el Derecho es la base que permite el funcionamiento y cooperación entre instituciones, y que para desarrollarse frente a la sociedad requiere de un criterio previo de legitimación, y vertical, esto es, visto como los niveles de toma de decisiones apoyados en discursos con criterios personales 0 colectivos que incluso pueden modificar aún más las concepciones de las cosas dentro de un Estado; de ahí que "durante siglos en este procedimiento se fund[a]n las ideas de soberanía jurídica con las de soberanía política" (LUHMANN, 2005, p. 363).

Por supuesto se obviará si existe coordinación o subordinación de la Política frente al Derecho, o viceversa; aquí los vamos a examinar a partir de la teoría sistémica que se explicará a continuación como sub-sistemas independientes inmersos de un sistema más grande llamado Sociedad, dado que podemos de esta manera individualizarlos; de la misma forma, una vez dejados en contexto los conceptos teóricos, en la siguiente parte de la investigación nos 
detendremos en cada sub-sistema, es decir, explicaremos la forma de su estructura para después de ello analizar su función y la manera en que acciona cada uno a las adversidades de distintas índoles.

A continuación, expondremos algunos de los lineamientos conceptuales sobre los cuales nos basamos para nuestra construcción teórica sin que con ello se quiera abarcar toda la magnitud de la obra Teoría de los Sistemas y mucho menos sintetizar lo que a su autor le tomo más de treinta años. Así las cosas la explicación decantada será tomada de acuerdo a nuestros propósitos investigativos aunque se dejará obviamente la estela de las obras que se relacionaron en la bibliografía especializada.

Con todo, nuestro cometido fijará especial atención sobre: sistema, entorno, causalidad, sub-sistema, autorreferencia, complejidad, autopoiesis, observación, estructura, método funcional, interpenetración, y expectativa; todos ellos a partir en principio de las apreciaciones teóricas del profesor NIKLAS LUHMANN (1998). Comenzando, dejaremos planteado que los estudios adelantados pertenecen al campo de la sociología. No obstante, se percibe que incluso para llegar a crear dicha formulación sistémica, el propio LUHMANN se valió de otros desarrollos interdisciplinarios un tanto distantes de la sociología fundamental.

Lo anterior nos sirve también de justificación para nuestros propósitos como son los de definir democracia pero desde la hibridez de conocimientos que a 
la postre esperaremos nos ayuden a desarrollar un aporte distinto pero significativo en la manera de entender a nivel dogmático la democracia. Aquí la conceptualización nos servirá para construir unas redes que conecten la realidad objetivamente puesta vista desde los aportes científicos y así comprender un tanto lo complejo que se pueden tornar situaciones de las cuales creemos son comunes. Por lo tanto, a las definiciones que lleguemos en todos los niveles, deberán leerse como restrictivas a la multiplicidad de nociones existentes para así no alejarse del contexto sistémico como quiera que, bajo otras condiciones conceptuales sería completamente insostenible afirmar lo que nos vamos a proponer.

Entrando a explicar la noción de <<sistema >> intentamos partir de una noción clasificatoria de las cosas presentes en el mundo y que si se quiere podemos agruparlas para diferenciarlas entre sí. Del mismo modo como generaremos grupos, éstos a su vez quedarán en niveles para así llegar a determinar de dónde partiremos. Lo dicho guarda similitud con una de las ideas con las que LUHMANN (1998) inicia la obra de Sistemas sociales, lineamientos para una teoría general. Para él, "la afirmación <<hay sistemas >> sólo quiere decir que hay objetos de investigación con tales características que justifican el empleo del concepto de sistema" (p. 28).

Así pues, como lo anterior nos sirve más de manera metodológica, queda justificado la forma de agrupar una serie de situaciones, elementos 0 acontecimientos y designarlo como sistema, siendo de esta manera la misma 
opción para que al interior de éste se construyan otros sub-sistemas, lo cual dependerá de la escogencia de información que se realice. De tal suerte coincidimos con que "los sistemas se constituyen y se mantienen mediante la creación y la conservación de la diferencia con el entorno y utilizan sus límites para regular dicha diferencia" (LUHMANN, 1998, p.40).

Más aún, al considerar examinar un objeto tomando como referencia la teoría sistémica, nos permite la posibilidad de llegar a describirlo, sin que sea necesario detenernos a examinar hasta su más mínima expresión, "sino que de una observación se pueden concluir otras" (LUHMANN, 1998, p.261), como es en efecto lo que pretenderemos más adelante al examinar el sistema social, pero entendido desde el elemento de las necesidades sociales que el entorno mismo nos facilita observar.

Vistas así las cosas, se hace pertinente centrarnos en la concepción <<entorno>> toda vez que ya se involucró dentro de las formulaciones teóricas. Por lo general y a nivel de los sentidos cuando nos referimos a un entorno generalmente pensamos en algo que nos rodea y no es extraño a nosotros. En igual medida sucede lo mismo a nivel de los sistemas, de ahí que "el concepto entorno no debe entenderse como una categoría marginal. La relación con el entorno es constitutiva de la formación de los sistemas y no tiene un significado $<<$ accidental $>>$ de acuerdo con la $<<$ sustancia $>>$ del sistema" (LUHMANN, 1998, p.172). 
Bajo ese entendido, comprendemos que para la formación de un sistema nos valemos de elementos, situaciones o formas propias de la sustancia que nos rodea, y en igual sentido, al constituirse así el sistema, su entorno será lo mismo que interconecto para crearse. De ahí que se pueda entender con posterioridad cómo al interior del sistema se crean otros modelos subsistémicos cuya influencia para su modelaje será lo propio que éste seleccione para nacer.

Como en este nivel nos encontramos hablando de apreciaciones generales, bástenos decir que existen relaciones del sistema general en su interior con otros sub-sistemas que se interconectan para lograr así movilidad de información entre ellos, sin embargo, existe en esa misma dinámica hechos de dominación o preferencia entre alguna de sus tantas formas, de ahí que "los sistemas operan necesariamente por autocontacto y no tienen ninguna otra forma de relación que ese autocontacto" (LUHMANN, 1998, p.56).

Ahora bien, que se haya clarificado la manera de comunicarse entre sistemas, no significa tener la posibilidad de predecir el actual futuro del propio sistema frente a una situación; para llegar a describir los efectos del entorno dentro del sistema emplearíamos la noción de <<causalidad>> como esa justificación influyente para un cambio no esperado, pero que no guarda relación con acontecimientos históricos. Esto nos permite concluir que no existe dentro de los sistemas sociales una fórmula que pueda contener respuesta previa a todo lo que le llega. (LUHMANN, 1998, p.177). 
Entones el entorno per se juega un papel preponderante de aquí en adelante constituyéndose en complemento del teorema empleado y bajo el cual se afirma: "el entorno es un estado de cosas relativo al sistema. Cada sistema se delimita a si mismo frente a su entorno. Por ello, el entorno de cada sistema es distinto" (LUHMANN, 1998, p.176). Es decir, no se puede llegar a generalizar al interior del sistema social que el mismo entorno de éste, guarde relación con otros sub-sistemas inmersos dentro del mismo sistema, asunto que dejaría sin piso entonces explicar el entorno de otros sub-sistemas y caería toda la teoría en una tautología.

Todo lo anterior nos lleva a seguir la siguiente proposición: "el sistema total se utiliza a sí mismo como entorno de la formación de sus sistemas parciales" (LUHMANN, 1998, p.33). Así pues, damos paso a lo que vamos a entender por <<sub-sistema >>, teniendo en consideración los mismos antecedentes formulados que al interior del sistema ya se han forjado: "cada sistema tiene que contar en su entorno con otros sistemas. Según la profundidad con que se considere el entorno, aparecerán en él más sistemas distintos" (LUHMANN, 1998, p.181).

Para intentar obtener mayor claridad y no entrar a confundirnos haremos la siguiente precisión: ya tenemos claro qué es un sistema, cómo se vale para existir y del mismo modo su diferenciación con el entorno. También alcanzamos a notar la posibilidad que al interior del sistema existan otros 
sistemas. Esta homogeneidad en las palabras puede llegar a confundirnos entre sistema "general" y sistemas nuevos, en consecuencia, cuando tengamos que referirnos al sistema social lo denominaremos así, cosa contraria cuando encontremos un sistema inmerso en otro a lo cual lo llamaremos sub-sistema.

Al ya tener las apreciaciones generales de cómo surge un sub-sistema, y con la anterior precaución en la terminología señalada para evitar malinterpretaciones teóricas nos resta indicar: "un [sub]-sistema sólo puede constituirse y cambiar relacionando elementos, y nunca mediante la desintegración y la reorganización" (LUHMANN, 1998, p.45). Entonces, las orientaciones técnicas seguidas en su orden serían <<autorreferencia >> y $<<$ complejidad $>>$. Ciertamente en ellas encontraremos la mediación y manera cómo opera un sistema.

A nivel de <<autorreferencia >>, LUHMANN (1998) señala que los sistemas tienen una forma de regularse o mejor de funcionar siendo ello también punto de partida para diferenciarse con los otros sub-sistemas. Para hacer esto posible, cada sistema se auto-organiza a partir de la causalidad. Se puede decir sin exagerar entonces que el sistema se ve a sí mismo para regularse empero no le impide relacionarse con diversos entornos. Sin embargo, debe optar por sus propios elementos absteniéndose de tomar nada del entorno y así lograr "la unidad constitutiva consigo mismo" (p.55). 
Cambiando de tema, el desarrollo del siguiente concepto nos va a enfrentar con el empleo de una palabra bastante común y una textura abierta tan amplia que perfectamente se corre el riesgo de entender cualquier cosa, por esta razón nos corresponde entrar a explicar en esta investigación como se tomara el concepto de complejidad. Podemos comenzar diciendo que sobre la anterior noción ya EDGAR MORIN (2007) elaboró la teoría del pensamiento complejo con una extensa obra de casi siete tomos como bibliografía especializada. Pero en su obra de Introducción al pensamiento complejo, intenta ubicar al lector en unos sencillos parámetros para abordar lo que sería una teoría que puede estar presente en cualquier actividad humana.

De ahí que empiece su escrito con la siguiente apreciación: "el término complejidad no puede más que expresar nuestra turbación, nuestra confusión, nuestra incapacidad para definir de manera simple, para nombrar de manera clara, para poner en orden nuestras ideas" (MORIN, 2007, p. 21). Con esta forma de comenzar, no sólo se está en presencia de algo verdaderamente difícil de manejar sino de conceptualizar, por cuanto "la complejidad es una palabra problema y no una palabra solución" (p.22).

LUHMANN (1998) por su parte, hace un poco más "complejo" el concepto de tal suerte que lo encontramos como "un hecho inevitable en cualquier nivel superior de la formación de sistemas" (.48), incluso, sostiene que la diferencia entre el entorno y sistema es justamente la complejidad entendida como 
progreso para valerse cada uno entre sí, por ello, un sistema no puede comprenderse asimismo qué tan complejo puede llegar a ser (p.50).

Tan disperso es el asunto que la complejidad termina volviéndose una respuesta a sí misma que dará como resultado la existencia de una dominación de un sistema sobre los otros. Y por ahí será como se perfile el concepto sobre el cual giraremos: <<complejidad>> nos indica que ésta "es independiente de su estructura real [al no estar] predeterminada <<materialmente >>, sino que puede ser determinada en cada nivel de formación de sistemas en relación con el entorno que [le] resulta relevante" (LUHMANN, 1998, p.46). Por lo tanto, tenemos entonces que en efecto, la complejidad no se define por lo que es, sino por la fortaleza que puede darle al sistema cuando se adhiere como consecuencia inevitable de su relación con el entorno.

En cuanto al contenido del concepto de <<autopoiesis $>>$ a simple vista podemos recordar a nivel biológico los procesos de regeneración celular, ello en principio no se diferencia tanto de lo pretendido a explicar, aunque la significación en teoría de los sistemas es discordante. Para ésta la autopoiesis se da "cuando algunas causas, pero no todas, se hacen necesarias para producir efectos determinados" (LUHMANN, 1998, p.43). Ello quiere decir que el sistema no escoge al azar; comoquiera que esa acción lo llevará a su propia conservación, de ahí que emplee una selección de elementos entre las múltiples opciones a las que pueda tener acceso siempre y cuando guarden 
relación con el propósito de su unidad lógica interna. Es decir, "el proceso de reproducción propio del sistema es utilizable sólo internamente. A la reproducción no se la puede utilizar como enlace entre sistema y entorno" (LUHMANN, 1998, p.56)

Lo anterior es de significativa importancia si se quiere evitar caer en el error de que un sistema pueda examinar por completo a otro hasta llegar a su origen y en dicho proceso encontrar las posibles coincidencias que guarde con el sistema invasor. Lo que no se puede ignorar es que el propio sistema pueda auto-observarse asunto que ya nos llevaría al concepto de autorreferencia.

Continuando, con el concepto de <<observación>> encontramos una herramienta muy empleada en la sociología al punto de llegar a ser considerado un instrumento. Casi visto como un elemento de la experiencia o "un estímulo (...) genéticamente condicionado" (POPPER, 2007, p.58), la observación necesariamente atraviesa por los sentidos. Por otro lado, y aislándonos un poco de lo que a la postre se concluirá, encontramos que "las observaciones sistémicas sólo adquieren en general valor y sentido para el hombre en tanto instrumento de conocimiento cuando desarrollan una idea [de aquello que se propone explorar]" ELIAS, 2008, p. 69).

Un tanto menos emblemático que los anteriores planteamientos, pero en el mismo sentido de lo que pretendemos conceptuar, HONNETH (2011) entiende que "el carácter observante, (...) es, propio de quien no toma partido o se 
mantiene en una neutralidad afectiva (...)" (p.36). Así las cosas, sería sencillo detenerse a contemplar un objeto sin mayor pasión o subjetividad simplemente para decir cómo es, pero en la teoría de los sistemas no tendría los mismos resultados, puesto que para LUHMANN (1998) "el observador no tiene libertad para designar cualquier cosa como sistema, [de ser esto así la teoría sistémica] perdería su sentido" (p.13).

En ese entendido, para centrarnos en los estudios sistémicos, ya se requiere un conocimiento ex ante de qué es sistema y con ello saber qué va a observar y si lo hace, podrá diferenciarlo del entorno, de ahí que será únicamente el observador a quien "le incumbe decidir qué sistemas le interesa observar en un momento de su existencia" (LUHMANN, 1998, p.13). Y en este punto la observación así entendida nos servirá de derrotero sobre el cual argumentemos el sub-sistema de la democracia y para ello tenemos que llegar a examinar otros sub-sistemas inmersos dentro del propio sistema social. Así las cosas, la observación empleada lleva consigo el "manejo de distinciones" (p.58) propia de lo que será para nosotros la política, el derecho, incluso la sociedad misma pero vista desde el punto de vista de las necesidades particulares.

De la observación a cuyo resultado empezaremos a buscar diferencias entre sub-sistemas, vemos necesario abordar el concepto de <<estructura >> para comprender si algunos sub-sistemas tienen similar armazón o si difieren entre sí, y a partir de cuantos elementos perceptivos o factores de la realidad 
podemos encontrar lo latente de ese objeto que estudiaremos de manera indivisa. De ahí entraremos a estudiar los aspectos diferenciadores para escribir la estructura misma del sub-sistema democracia distinguiéndola de lo que denominaremos sub-sistemas político o del derecho, incluso del mismo sistema social.

La estructura entonces nos permitirá a partir justamente de esa observación encontrar reglas permitiendo entender la movilidad misma dentro del sistema, mostrándonos con ello a manera metodológica una objetividad en el análisis cuando estemos explorando los distintos sub-sistemas, evitando así incurrir en supuestos o ideales metafísicos bajo el entendido que existen estructuras constantes y es a partir de relaciones como se puede comprender la noción de sistema. Es por lo anterior que LUHMANN (1998) entiende que las estructuras "deben posibilitar la capacidad de anexión de la reproducción autopoiética, si no quieren abandonar su propia existencia; esto limita el terreno de los cambios y de un aprendizaje posible" (p.58)

Así las cosas, las estructuras facilitarán detenernos a examinar la cohesión entre elementos del propio sistema y a su vez diferenciarlos de otros tantos con el propósito de explicar mejor las relaciones que no tienen un modus operandi propio sino más bien selectivo, por eso la estructura misma "no actúa como tal, no actúa con base en una fuerza interior; únicamente se adentra en experiencias diferenciales que permiten a su vez información, sin necesariamente determinar a priori lo que sucederá posteriormente" 
(LUHMANN, 1998, p.62). Sin embargo, la estructura deja abierta las posibilidades de cambio en lo que antes pudo haber considerado para funcionar permitiendo así generar la complejidad para su propia subsistencia o actualización.

Lo que resta por definir es la manera en que se crean las estructuras mismas, y no dejarlo tan abstracto cuando sostenemos lo que nos permite hacer. Pues bien, "la formación de estructuras no es posible en el vacío debido a que el sistema de formación de estructuras es autopoiético y presupone materiales y energías <<libres>> e independientes" (LUHMANN, 1998, p.208). La energía a la que el autor hace referencia la entendemos como aquella comunicación existente y constante dentro de propio sistema con la realidad donde como es de esperarse deben surgir enlaces que al estar unidos crean identidad propia de su objeto.

Y aunque la propia estructura es importante, todo parece apuntar a que ésta no es tan central dentro del proceso sistémico, más bien es un enlace generador de comunicación con otras estructuras dentro del sistema social y por estar dentro de éste, la propia movilidad de información hace que la estructura misma se pueda actualizar creando para sí sus propios límites, incluso, "la selección de la estructura puede estar también condicionada por estructuras ya existentes (tradición)" (LUHMANN, 1998, p.260). 
En este punto haremos un paréntesis para referirnos justamente a la posibilidad de influencias entre estructuras y a partir de dicha dinámica es como los sub-sistemas pueden tomar prestadas estructuras de otros sistemas con el propósito de formarse a sí mismos. Bajo este punto de vista se justifica la interpenetración en conjunto con otras nociones, concepto que se expondrá más adelante. Pero ante todo, podemos encontrar otra calificación para emplear el concepto de estructura, no entendida "como un tipo particular de estabilidad, sino por su función de hacer posible la reproducción autopoiética del sistema de acontecimiento en acontecimiento" (LUHMANN, 1998, p.262).

Así las cosas, frente al concepto de autopoiesis, la estructura juega su rol al momento de seleccionar no sólo su reproducción sino su vigencia, es como si existiera un antes de la estructura y un después de la autopoiesis donde se demarcan los límites de lo que será un sistema el cual buscara reducir la complejidad creando un orden de elementos para así poder determinarse y auto-organizarse según su propia realidad, tal como lo formuló LUHMANN (1998) al sostener: "la autopoiesis es, por lo tanto, la condición para que una estructura pueda o no cambiar" (p.316), sin que lo anterior quiera decir que los eventuales cambios son previsibles.

Hasta aquí tenemos unas herramientas conceptuales que nos permiten comprender en parte la teoría de los sistemas. Resta ahora entender el <<método funcional >> como aquel elemento explicativo a las diversas opciones que tienen los propios sistemas de encontrar alternativas dentro de 
su propia complejidad. Es decir, como en la mayoría de aspectos que pueden suceder entre sistema y entorno se puede hablar de una multiplicidad de opciones selectivas, el método funcional nos permite observar todas esas posibilidades existentes.

Pero como dicho método únicamente brinda opciones de selección, esto hace complejo que otros sistemas puedan heredar la misma opción para enfrentar su propia complejidad, toda vez que no estaría dentro de las éstas alternativas propias azar la similitud de soluciones entre un sinfín de circunstancias. Con todo, lo perseguido con este nuevo concepto es descifrar las estructuras y sus funciones dentro de las varias posibilidades que pueden llegar a existir. LUHMANN (1998)

Pasando a otro escenario conceptual, en la <<interpenetración>> se da una relación entre los sistemas donde su complejidad es necesaria para crear otro estado de cosas, incluso un sistema nuevo. Como se ve, surge "una selectividad y una capacidad de conexión distintas, un pasado y un futuro distintos" (LUHMANN, 1998, p.203) para la creación de sistemas sociales partiendo de la propia realidad que es en su conjunto desorden-complejidad-. Es de anotar que el propio profesor LUHMANN, (1998) fue enfático en evitar que la imaginación comprendiera esta herramienta a partir de la teoría de los conjuntos, por el contrario, para entender la interpenetración es necesario concebir a partir de los propios límites existentes entre sistemas, cómo el 
sistema naciente hace abstracción de los sistemas vigentes diferenciándolos para sí pero sin llegar a desintegrarlos (p.205).

Nuevamente aquí el concepto de autopoiesis se toma como referencia para dicha operación como condición previa para el surgimiento de los sistemas sociales, empero surgen unas relaciones de dependencia frente a otros sistemas especialmente a nivel estructural, y cuando no llega a ser posible ese acoplamiento entre estructuras para el surgimiento del nuevo sistema, se desintegra, por eso dentro de dichas operaciones, serán los enlaces de selección los que darán sentido a esa formación naciente.

Y quizá el punto de mayor argumentación frente lo que en adelante nos dedicaremos a contextualizar es en la manera como la complejidad será tratada. Es decir, no pretendemos replantear el caos que pueda existir en el entorno justificándolo con la creación de un nuevo sub-sistema, básicamente el interés es justamente otro, como la existencia de problemas es habitual, se crean enlaces para nuevas estructuras pero no con ello solución a los obstáculos encontrados, incluso el sistema naciente puede heredar problemas y plantear a su vez nuevos conflictos. De ahí que LUHMANN, (1998) sostuviera:

"La interpenetración conduce a la inclusión en la medida en que la complejidad de los sistemas aportadores es utilizada también por los sistemas receptores, pero asimismo conduce a la extensión en la medida en que una 
pluralidad de sistemas interpenetrantes tienen que distinguirse unos de otros en su autopoiesis para posibilitar la interpenetración" (LUHMANN, 1998, p.207).

Ya para concluir entendemos apropiado explicar un concepto del cual nos valdremos y será objeto de varios enunciados al momento de tratar los subsistemas que nos hemos propuesto examinar dentro del sistema social. Así en las propias estructuras se observen que una de sus funciones a nivel teórico es reducir la complejidad, de dicho proceso se generaran expectativas y será esto lo siguiente a exponer. La <<expectativa>> según LUHMANN (1998) es, por lo tanto, una estrategia para crear una relativa aseguración contra irregularidades (p.281).

Llega a ser comprensible la manera de entender una expectativa si se le entiende como un resultado de ideas-reflexión donde en última instancia se espera algo frente a una problematización. Los obstáculos empiezan a surgir cuando en vez de resolverse los procesos caóticos aparecen elementos a la espera de ser seleccionados por sub-sistemas como alternativas o identidades para auto-regulaciones futuras, empero lo inevitable es el surgimiento de mayor complejidad sin que se resuelvan los obstáculos planteados al inicio, comoquiera que, ahora los nuevos presupuestos tendrán que tratar lo inmediato -el presente-.

En cuanto a las expectativas, existe una diferenciación entre cognoscitiva y normativa, las últimas abordan más el tema del sub-sistema del derecho y son 
aquellas que nos permiten ser exigidas cuando existe una defraudación, de ahí que "la expectativa normativa, contrafácticamente se refuerza, sobre todo, mediante el hecho de que el expectante adquiere el derecho a mantener su expectativa y de sostenerla públicamente, a pesar de la decepción" (LUHMANN, 1998, p.294), asunto completamente diferente cuando nos referimos a las cognitivas las cuales, al no ser satisfechas se crea la opción de comportamiento negativo. Lo trascendental de lo anterior, será aquello a lo que el observador busque detenerse dentro del sistema para determinar los grados de expectativas.

Hasta aquí, cerramos las apreciaciones conceptuales que darán base a nuestra investigación, bástenos decir que, aunque el recorrido de la obra de LUHMANN (1998), es bastante denso en cuanto a contenido, sin embargo, con lo expuesto en estas once definiciones teóricas soportaremos los estudios de los sub-sistemas político y del derecho a partir de su diferenciación en torno al sistema social, incluso, iremos más allá de las definiciones para llenar el contenido de las propias estructuras con aportes doctrinarios de otros autores.

En lo que sigue, abordaremos el problema de la indeterminación de los conceptos propiamente hablando, podemos observar que tanto la política como el derecho, de manera alegórica y bastante irresponsable, exponen discursos para justificar sus $<<$ nociones $>>$ de democracia, conduciéndonos con ello a un juego del lenguaje en diferentes estadios, donde la variable del significado dependerá de lo que se entienda por esto o por aquello. 
Descifrado el primer obstáculo y para evitar incurrir en posibles falacias o indefiniciones, se pretende, siguiendo el "materialismo conceptualista y ficcionista" expuesto por BUNGE (2006), intentar redefinir el actual modelo democrático tomando como base su propia estructura a partir del "objeto conceptual" (p.54); esto es, buscaremos la re-definición del concepto democracia una vez tengamos identificados conceptualmente los otros subsistemas de los que a nuestro parecer y tal como se demostrará se vale la democracia los cuales son: la política como primera manifestación del Estado, regulada por el derecho dentro de la sociedad como sistema general que reúne a todas las personas y de donde se extraen todas las necesidades

Lo anterior nos permitirá justificar un concepto de democracia previa explicación de otros elementos que denominaremos sub-sistémicos los cuales expondremos de manera detallada. Así, pues, y en concordancia con lo expuesto, siempre se observaran influencias conceptuales de algún elemento jurídico, político o social que modifique las bases mismas de la democracia.

Entonces, a fin de aclarar aún más las diferencias y a su vez para justificar una demarcación temporal y espacial, nos proponemos concebir la democracia para efectos del presente estudio a partir de un determinado contexto, esto es, dentro de un Estado social de derecho a partir de 1991, por lo menos en lo que al sistema colombiano se refiere, y a partir de allí desarrollaremos los elementos conceptuales que encierran la democracia. 
De esta forma obtendremos una re-definición de la democracia, que aunque es "fingid[a] o convencional" (BUNGE, 2006, p. 54), podemos llegar a explicar nuevos elementos, reformas en su estructura o cambios en su función, tal como lo percibimos del pasado en países europeos que, siendo democráticos, reflejaban cambios en sus funciones con ciertos matices autoritarios. Finalmente, una vez concebido el concepto identificable y existente, lo podemos pensar, imaginar y contrastar de manera empírica.

\subsection{IDEAS, TEORÍAS O CONCEPCIONES QUE AYUDARÁN A DESCRIBIR LA DEMOCRACIA}

En este punto nos permitiremos exponer algunos de los mejores aportes de los diversos autores consultados, cuyas definiciones teóricas nos hayan orientado a justificar cada sub-sistema, pero sin enmarcar lo descrito en las dos categorías generales que para nuestros días los teóricos de la democracia nos hablan; esto es, no involucraremos la re-definición de la democracia dentro del sistema empírico, es decir, aquella práctica democrática de Inglaterra y los Estados Unidos en donde prevalece más el factor social que lo político. Del mismo modo, evitaremos encasillar todo el estudio en teorías con una fuerte tradición racionalista percibida en la mayoría de los países de Europa, donde es tenido más en cuenta al ciudadano como individuo aislado de la cobertura democrática en lo social. 
Nuestro análisis al ser multidisciplinario adoptará múltiples posturas doctrinarias bajo el entendido que "(...) una cosa, una idea, una teoría puede ser conjeturada como objetivamente valiosa si ayuda a resolver un problema, independientemente de que su valor sea conscientemente apreciado por aquellos que se oponen en resolver ese problema" (POPPER 1994, p. 260), incluso, por más que en el intento de abordar otros saberes podamos incurrir en lo que a HAROLD BLOOM (2009) denominó malinterpretaciones teóricas, esto es, decir algo más allá o con fundamento en lo leído por más que le aleje del tenor literal de la propia proposición.

Ahora bien, aplicando lo anterior, queda justificado el trasplantar autores y extraer de sus formas dogmáticas, bien de manera textual o por medio de interpretación la búsqueda de apreciaciones que nos permitan describirle al lector un estado de cosas tanto dentro como fuera de la democracia, y no a partir de conjeturas sino con el sustento y la rigurosidad que exige el tema a estudiar. Finalmente, el escoger teorías multidisciplinarias y temas de: comunicación, acción, poder y decisión, sociedad, derecho y política, más no partir de la democracia per se, sirven para tener una lectura de la democracia colombiana no subjetivizada por bandos o ideologías.

Una vez sentadas las explicaciones de Estado, Sociedad y Derecho tanto en su estructura como la función, se argumentará la denotación ${ }^{1}$ de lo que

1 Para el profesor italiano GIOVANNI SARTORI la denotación (o extensión) se predica a esos objetos -o situaciones- a los cuales el concepto los puede definir. 
formularemos conceptualmente es democracia a partir de la interpenetración de los sistemas ${ }^{2}$; de esta manera el contenido de democracia apuntará como se esperaría, a validar nuestra hipótesis expuesta, esto es: democracia per se no subsiste por sí misma ni tampoco se vive en democracia ${ }^{3}$.

Al parecer, lo que se genera es un discurso que se emplea cada periodo constitucionalmente estipulado, donde los agentes matriculados, indistintamente a los sub-sistemas político y/o del derecho, generan situaciones ex ante que apuntan a los sentidos, emociones e incluso a las necesidades de las personas del común -sociedad-, para que éstas esperanzadas porque serán atenidos sus reclamos tengan un motivo para ir a las urnas, lo cual nos permite inferir que con dicho ejercicio se crea el subsistema de la democracia, por determinado tiempo y durante un espacio breve ${ }^{4}$, proceso que ratificará la legitimidad de la elección del gobernante al decir que fue elegido a partir de los medios democráticos; no obstante, el subsistema de la democracia desaparece al igual que la ciudadanía una vez

\footnotetext{
2 Noción explicada por NIKLAS LUHMANN en su obra ¿Cómo es posible el orden social?, de la cual se extrae cómo es que varios sub-sistemas pueden crear uno nuevo y sobre la cual tomaremos como argumento para validar la construcción de la democracia.

3 Entre la extensa forma de concebir la democracia hay quienes piensan en un aspecto evolutivo de dicha institución, en donde al crecer demográficamente la población se hizo necesario pensar en herramientas que ayudaran a que las decisiones contaran con el voto de la mayoría, para lo cual se habló de democracia directa en el entendido que es el mismo ciudadano quien decide con su voto sobre los asuntos que afectan el interés general; y de democracia representativa, cuando se faculta a un candidato para que siga un mandato de varios ciudadanos, es decir, su voz será la de muchos a quienes les debe el mandato. Pero independiente de lo anterior, el vivir en democracia apunta a las $<<$ promesas $>>$ que llevaron al cargo a ese político muchas veces quedan desprovistas de elementos jurídicos que exijan algún tipo de responsabilidad por lo no hecho o dejado de hacer -omisión democrática-.

${ }^{4}$ Aquí hacemos alusión a que los procedimientos para elegir gobernantes duran en promedio un día y máximo dos semanas en verificar el conteo de votos.
} 
finalizadas las elecciones, incluso muchas veces la sociedad misma llega a ser despreciada pero etiquetada como necesaria, bajo el entendido que nuevamente volverán a ser útiles en los próximos comicios.

Una vez re-definido <<democracia $>>$, en el siguiente paso planteamos un análisis de "observación de un hecho [particular] y las proposiciones que lo representan" (BUNGE, 2006, p.29), esto es, ver el concepto justificativo de democracia aplicado dentro de la sociedad colombiana en un escenario concreto como son las elecciones populares para elegir gobernantes, en donde encontramos toda una serie de garantías dentro del sub-sistema jurídico, que promueven los procedimientos para el cambio de gobierno o de representantes, más no una satisfacción plena de aquel mandato conferido y para lo cual se le dio tanto $<<$ poder $>>$, lo que nos va a permitir concluir al final de la investigación una serie de apreciaciones a nivel de aportes por los contrastes obtenidos entre teoría y estudio particular.

No solo basta con buscar teorías que expliquen democracia como subsistema. En este punto y después de lo recolectado en los niveles anteriores, someteremos nuestra construcción conceptual a Colombia a partir de sus dinámicas de distribución del poder. Para ello, se tomará como campo de ejemplificación el gobierno local de Bogotá, D.C. durante el periodo del burgomaestre Gustavo Petro, y se explicará el mecanismo establecido por la Constitución cómo es el voto programático y la revocatoria del mandato 
gestada en pro de un mandato normativo-constitucional, para finalmente concluir si nuestra hipótesis se contrastó, o por el contrario se desvirtuó. 


\section{ESTRUCTURA DE LA DEMOCRACIA}

Al pretender fijar los conceptos de la estructura democrática por lo menos en Colombia, primero vamos a entrar a demostrar cómo interactúan tres enlaces diferentes, los cuales al parecer le dan sustento a la democracia misma, esto es, la política, y el derecho que, tal como LUHMANN (2005) sostuvo, y sobre lo cual nos guiaremos dentro de sus lineamientos teóricos para comprender dichas instituciones como sub-sistemas, "se trata, pues, de diferentes subsistemas [dentro] del sistema llamado sociedad" (p. 473).

Una vez expliquemos los sub-sistemas de manera aislada, política-derecho dentro del sistema social -sociedad-, a renglón seguido entraremos de lleno a desarrollar el objetivo general que en esta investigación trazamos, esto es, explicar el sub-sistema de la democracia, la cual tiene como estructura el Estado y el Derecho, además cuya base histórica ha sido el pueblo, concepción que hoy sonaría por demás despectiva y a la cual denominaremos a partir de la concepción sistémica y durante todo nuestro recorrido, la sociedad.

Ciertamente, los respectivos estudios se harán desde la teoría de los sistemas, en el entendido de estructuras diferentes con funciones únicas pero que no solo se dejan influenciar de la misma sociedad, incluso entre sub-sistemas 
pueden compartirse elementos o llegado el caso, a partir de sus mismos canales tal como lo expusimos en la primera parte, formar un sub-sistema nuevo que como creemos es como se forma la democracia.

Entonces para empezar, y recordando la primera convención de orden metodológico §1, págs. 23 y 26, hemos de remitirnos a la Constitución de 1991 donde encontramos dentro de la propia sociedad dos diferencias subsistémicas expresas en el artículo $1^{\circ}$, esto es, las nociones de Estado y Derecho, las cuales "varían de acuerdo al grado de diferenciación del sistema y de acuerdo con la evolución social" (LUHMANn, 2005, p. 9). Es así como nos alejaremos de ideas centrales o teorías del "Estado social de derecho" para ver cada uno de manera independiente.

Ciertamente, el núcleo en torno al cual giraremos será la expresión denominada "sistema", la cual siguiendo un buen manejo de los conceptos $\S 1$, pág. 23, entenderemos por ésta y, a partir de LUHMANN (2005), como aquel "entramado de operaciones fácticas que, como operaciones sociales, deben ser comunicaciones" (p. 96). Así las cosas, comprenderemos la Constitución del 1991 para Colombia como el referente que se da entre las diversas instituciones del Estado y la sociedad donde se inscriben otras formas subsistémicas. 


\subsection{El SUB-SISTEMA dE LA POLÍTICA}

Es posible que a nivel dogmático a partir de HOBBES (2005) encontremos la noción de Estado como primera manifestación política, donde se percibe una categoría de legitimación traducida como <<soberanía >>; en nuestros días dicha formulación radical aparece en el Preámbulo de la Constitución de Colombia de 1991, donde se hace hincapié que pertenece al pueblo 5 .

También encontramos de una manera un tanto distinta a la anterior, pero con elementos que nos servirán más adelante, como WEBER (1995) concibe la propia noción de política como "aquella (...) dirección o influencia sobre la dirección de una asociación política, es decir, en nuestro tiempo, de un Estado" (p.82) donde está latente la dominación de unos hombres con relación a otros a partir de algo característico en dichas dinámicas y es que "quien hace política aspira al poder; al poder como medio para la consecución de otros fines (idealistas o egoístas o al poder $<<$ por el poder $>>$, para gozar del sentimiento de prestigio que él confiere" (p.84)

La concepción política toma mayor fuerza en la Edad Media, donde el rey en el Estado-Nación tenía potestad de dirigir, pero a su vez el pueblo lo reconocía para obedecerlo como soberano, de lo cual se derivaba un estado de bienestar para los ciudadanos; de allí que "el poder del príncipe se originaba en un

\footnotetext{
${ }^{5}$ Al respecto se puede consultar el Preámbulo de la Constitución de 1991.
} 
contrato celebrado originariamente entre el príncipe y el pueblo como una totalidad” (Ross, 1989, p. 26). Dicho esquema prevaleció en el sistema inglés por cuanto se dejaba de lado la aristocracia y prevalecía una dinámica en donde el monarca servía a su pueblo.

Bajo esta concepción, en donde la autoridad venía del pueblo, los doctrinantes de la época lo llamaron soberanía popular; posiblemente se buscó después de la Revolución Francesa manejar una voluntad general explicada por ROUSSEAU (2010) con ciertos matices del toque inglés, pero llevados a un racionalismo romántico según lo explica Ross (1989), cuando al analizarlo comprendió que "la voluntad general es por tanto no sólo legítima -puesto que se funda en el libre consentimiento de los individuos-, sino también útil -en cuanto está dirigida al bien común- y equitativa, puesto que muestra igual consideración para todos" (p. 54).

También se ha visto que dentro del sub-sistema político existen según SCHMITT (2011) dos principios presentes en su actividad como es la identidad y representación (p.270); el primero hace mención a que el Estado encuentra en la totalidad de sus miembros una unidad política bajo el supuesto organizacional de un territorio, no obstante y dada la extensión de la misma sociedad, dicho precepto tenía que ser reformulado. Así las cosas, la representación se da como una solución al anterior obstáculo siendo esta no "un fenómeno de carácter normativo, no es un procedimiento sino algo 
existencial" (p.276), como respuesta a la complejidad de reunirse la comunidad en un sitio público.

Aquí al igual de cómo será explicado en §1, pág. 86, cuando examinemos el mandato que la ciudadanía le da al político, "la representación en Derecho político es distinta por completo a la representación en Derecho Privado. Por eso no pueden aplicarse a aquella los postulados fundamentales válidos para ésta" (ScHMITT, 2011, p.275), entonces le corresponde al político un trato diferente alejado del derecho en principio pero que en últimas brindará al representante la legitimidad para permanecer en la asamblea o en la dirección del poder ejecutivo.

Sin embargo de lo anterior se genera una polémica cuando se precisa que legitimidad y representación son conceptos dentro de lo político completamente diferentes, por cuanto lo primero confiere ese poder para la toma de decisiones, mientras lo segundo, reflejaría una manera de gobernar en nombre de todos buscando unidad de todas las partes que integran el Estado.

Así entendidas las cosas, en las comunidades organizadas, ahora llamadas Estado-Nación, se empezó a instituir una especie de orden, el soberano debía garantizar determinadas condiciones de convivencia dentro de su territorio, éstas no quedaron asumidas por el Derecho como sistema análogo a decisiones gubernamentales como sí en la política misma; "esto remite a que 
la evolución del derecho se hace dependiente de la evolución (que se da en paralelo) del sistema político" (LUHMANN, 2005, p. 343).

Bajo el anterior supuesto, se entenderá la categoría de soberanía dentro del campo político como un símbolo mediante el cual un grupo determinado de personas que viven en un mismo territorio, al reconocer que poseen unas mismas características estando cobijados no sólo por unas mismas costumbres en las cuales se identifican, sino que para evitar las guerras entre ellos mismos, acuerdan que "el uso de la fuerza física, aún en última instancia, aún como extrema ratio, es el carácter específico del poder político" (BoBBIO, 1985, p. 6).

Otro aporte que Bоввıо (2014) hace de la descripción del sub-sistema político consiste en que una de sus funciones sería justamente la realización de los objetivos que se propone dentro de su actividad a nivel institucional "al subsistema político corresponde la función del goal-attainment, lo cual quiere decir que la función política realizada por el conjunto de instituciones que constituyen el Estado es una de las cuatro funciones fundamentales de todo sistema social" (p. 77).

Y quizá su apreciación se debía a su formación como docente pero también como político que fue, aunque con posterioridad hablaría del futuro de la democracia (1984) y en una conferencia sobre la democracia y secreto (1988), su pensamiento hasta entonces predicaba que "la función de las instituciones 
políticas es la de dar respuesta a las demandas que provienen del ambiente social o, de acuerdo con una terminología común, de convenir las demandas en respuestas" BовBIO, 2014, p. 78). Dicho panorama lo entrará a debatir dicho autor cuando trate el tema del contractualismo y el gobierno de los técnicos: por nuestra parte, nosotros lo abordaremos cuando expliquemos la figura del mandato §1 pág. 86.

Así las cosas, encontramos en el sub-sistema político no sólo la disposición y control de la fuerza cuando se llega a la esfera pública del gobierno sino además la realización de objetivos y la respuesta o imposición según las razones propias del Estado. De ello lo que más va a predominar hasta nuestros días es la sustracción "a la sociedad la disposición del poder violento físico y, sobre esta base, construye su propio poder" (LUHMANN, 2005, p. 343), buscando representarse a partir de organizaciones democráticas en donde cada decisión que se tome irá ligada a la voluntad general de aquellos que no sólo se identificaron mayoritariamente con lo convenido, sino frente a los demás que no hayan celebrado dicho pacto o representación política de intereses.

En este sentido podemos concebir la noción actual de soberanía como primer elemento del sistema político, donde "la democracia pudo desarrollarse en la medida en que su espacio quedó restringido al Estado y a la política que éste sintetizaba" (SANTOS, 2004, p. 8), y que reflejados dichos efectos en el entorno todos quedan obligados, incluso los que no participaron en la elección del 
nuevo mandato, únicamente porque los criterios de soberanía, voluntad general y mandato se actualizaron en cabeza de un gobernante a partir de un criterio mayoritario.

Ahora bien, en lo que a la teoría se refiere, conviene desde luego ver cómo es la autopoiesis del sub-sistema político, vale decir, cómo se regula a sí misma. Sobre este fundamento se requiere explicar la existencia de determinados agentes que son los que estructuran el sub-sistema político desde su interior, tal como afirma SARTORI (2010), y aunque no podamos percibirlo así, existen "leyes que el político «debe» aplicar" (p. 209), como aquellas que son las que mueven lo político -autorreferencia-, pero no entendidas al nivel de normas jurídicas toda vez que éstas corresponden a otro ámbito, el cual se expondrá más adelante.

Con un pensamiento un tanto similar, SCHMITT (2011) logro encontrar cuando se empezó a desarrollar las nociones de representación, cómo "el diputado se convirtió en agente dependiente de organizaciones de electores y de intereses, el pensamiento de la representación desapareció ante el principio de la identidad inmediata" (p.284), así entonces, no se crea tanto una representación general, en pro del bienestar de la sociedad sino movimientos de interés contrarios a esa unidad del Estado, asunto que más adelante será relevante para determinar las nuevas tendencias del sub-sistema de la democracia. 
Otra forma de entender esas "leyes" se observan en la manera cómo el político aumenta sus ingresos; unas veces por regresar favores a lo que la doctrina especializada §1 pág.75, ha llamado burocracia o distribución de cargos. Aquí el criterio diferenciador reside en separar dos aspectos; una cosa es nombrar al representante y la otra indagarse la manera o los intereses que tenía éste para llegar al poder público tal como lo podía percibir WEBER (1995), al encontrar que, "quien vive <<para >> la política hace $<<$ de ello su vida $>>$ en un sentido íntimo; [sin embargo] todo hombre serio que vive para algo vive también de ese algo" (p.96), pero aquí alejado el autor de los intereses humanos de reivindicación de la sociedad oprimida, o el simple gusto por el poder, el político comprende que así como la gente del común trabaja para percibir un ingreso, del mismo modo, "quien vive $<<$ de $>>$ la política como profesión [hace de ella] una fuente duradera de ingresos" (p.96).

Quizá la línea de pensamiento es algo similar en distintos autores habida cuenta que incluso para el mismo BOURDIEU explicado por los autores MORENO y RAMíREZ (2006) encuentran que cuando un sujeto "ingresa a la política, al igual que alguien que entra a una religión, debe sufrir una transformación" más aún, dentro de la propia política nos continúan explicando existen unas "<<leyes de hierro >>, (...) concentración de poder en un pequeño grupo" (p.35), que para nosotros es el mismo sub-sistema político donde en últimas sólo prevalecen intereses propios. 
Al parecer SARTORI (2010) se refiere más a decisiones internas que buscan regular el sistema político mediante la fijación de compromisos de cooperación entre los mismos sujetos que se encuentran inscritos al interior del sub-sistema de la política, y todo con un propósito: llegar a crear una jerarquía de poder y así mostrar en el sistema social quién eventualmente se perfilaría como posible gobernante. No obstante, también dentro de esos pactos se generan conflictos que a su vez producen nuevas alternativas de acceso al poder, pero siempre cobijados bajo el doble discurso de obtener el mayor beneficio a la colectividad, pues será la sociedad calificada para poder votar la que avale el ascenso a los cargos de elección popular.

Pero esas reglas o reuniones pactadas no públicas, son lo que BoBBıO (2013) definió como secreto y por ende completamente ilegítimas dentro del subsistema de la política. Para explicar su preocupación empleó una frase de KANT cuando en su obra paz perpetua sostenía que "<<todas las acciones referentes al derecho de otros hombres, cuya máxima no es compatible con la publicidad, son injustas >>" (p.53). El profesor italiano realmente no quiso elaborar una teoría sobre los daños de ocultar pero sí dejo bien en claro cómo dentro de la misma dinámica interpartidista se guardan asuntos donde se define el futuro de la sociedad, pero que a la postre, ésta no se da ni por enterada, siendo tan notorio lo anterior que prefirió dejarlo consagrado de la siguiente manera:

"son inherentes a la acción política, tanto la que corresponde al poder dominante como a la del contrapoder, dos técnicas específicas que se 
complementan mutuamente: sustraerse a la vista del público en el momento en que se realizan deliberaciones de interés político, y ponerse la máscara cuando se está obligado a presentarse en público". (ВовВІо, 2013, p. 46).

Ahora bien, independientemente de los elementos que nos permitió observar el sub-sistema de la política, encontramos una estructura fachada de ideales por lo menos a nivel teórico y del discurso donde se intenta justificar y mantener una relación únicamente entre soberanía y voluntad general, entendida como aquella conveniencia que permite estabilidad en el poder al dirigente político, por cuanto es el mismo mandato que se le otorga al soberano aquella herramienta que legitima al pueblo para llegado el caso revocarlo de su cargo.

Por ello, para justificar la relación entre mandato y poder, el político debe realizar acciones que llamen la atención del individuo y pequeños grupos marginados en donde se generarán, como es de esperarse, expectativas y pluralidad de significaciones en torno a los fines políticos y las reglas del Derecho mismo tales como bienestar general, eficacia de las instituciones, críticas al gobierno de turno o incluso oposición a otros partidos políticos en aras de la colectividad, y todo con un único fin y es ir tras algo ulterior, como por ejemplo tener más poder o influir más en los comportamientos sociales.

Otro aspecto relevante dentro del sub-sistema político consiste en el incumplimiento de sus actos pre-electorales, es decir, una vez el gobernante 
se encuentre posesionado puede suceder que no siempre éste cumpla con las promesas declaradas, generando defraudación o una negación de las bases mismas de la legitimidad política que lo llevó al cargo, en la medida en que el apoyo electoral obtenido no se ve reflejado en la obra de gobierno para lo cual se produjo la elección, por ello "la lógica operativa del contrato social se encuentra, por lo tanto, en permanente tensión con su lógica de legitimación" (SANTOS, 2004, p. 3), toda vez que lo esperado a partir del mandato no se refleja en el proceso de gobernabilidad estipulado.

No obstante, a lo anterior se le suma un aumento de complejidad cuando se ven factores como "el subsistema partidista y el subsistema de los grupos de presión" (SARTORI, 2010, p. 220), esto es, personas insatisfechas al no estar conformes con la estructura política o forma de distribución del poder político, que entablan campañas desde el interior de la sociedad traducidas en patriotismos del ciudadano común quienes, movilizados por un sentimiento nacional, buscan sus intereses en los procesos de elección.

Hasta aquí podemos comprender cómo al mismo tiempo los grupos de oposición atacan la estructura del sistema político buscando nuevas disposiciones para adquirir un status, lo cual no es otra cosa que el manifiesto "del burguesismo, esto es, la pasión de la clase burguesa por afirmarse contra aquello que le amenaza" (BENDA, 2008, p. 100). 
De aquí, si la oposición llega a tener éxito los que han comprendido lo selectivo del mensaje de defraudación de las expectativas de una comunidad no hacen otra cosa que convenir en beneficio esa insatisfacción o necesidades sociales en un interés propio para llegar en los futuros procesos de repartición del poder al escalafón esperado. Con todo, se desprende la función del sub-sistema político, esto es, el medio para aspirar al poder público proveniente de un pequeño grupo social que ha logrado tener acogimiento político.

Por lo visto, dicho esquema expuesto vulnera los ideales que los sistemas empíricos democráticos mantienen "actualmente" en un discurso ya poco creíble, esto es, servir a la comunidad. De igual forma tampoco se acopla lo anteriormente descrito al esquema racionalista individualista del modelo occidental de la democracia, porque no se beneficia una sola persona dentro de la misma sociedad. Contemplado desde los planos anteriores, se coincide con SARTORI (2010) cuando sostiene que "condicionar e influir sobre el poder político no es lo mismo que ejercerlo" (p. 221), entonces da lo mismo que el sub-sistema político prometa hacer mucho por la sociedad si poco o nada se cumple, quedando con ello desvirtuados los modelos tradicionales de la democracia y abriéndonos paso a que nuestra alternativa de una nueva propuesta pueda ser válida.

Concluyendo lo anterior, tenemos la estructura del sistema político, con los elementos descritos como son: la soberanía, voluntad general, autoridad cedida, el mandato, las decisiones, los acuerdos, cooperación, el conflicto 
interpartidista, y finalmente la forma en que se cede el uso de la fuerza delegado en unos pocos. Así pues, observamos una hibridez §. p11. en torno a la función del sub-sistema político pero no de manera independendiente. Éste depende de dos premisas sobre las cuales se vale dicho sub-sistema para comunicarse tanto con la sociedad como con el sub-sistema del derecho comoquiera que "el poder [conferido por el sistema político] no es un complejo completamente autosuficiente, sino que depende de otros factores, tanto para las condiciones que lo hacen posible como para su nivel de demanda y necesidad” (LUHMANN, 2005, p. 85).

\subsection{EL SISTEMA DE LA SOCIEDAD}

De la sociedad se ha escrito tanto como de la democracia, pero ha venido cambiando la forma en que se concibe; en la antigüedad los clásicos hablaban de la noción de ciudadano más no una sociedad compacta, en la Edad Media de siervos, nobles y su jerarquía organizacional, y así hasta llegar a la noción <<pueblo>>; tiempo después se estratificó llegando a la sociedad alta y baja,

de ésta salieron los movimientos populares y corporativos hasta llegar a la modernidad.

Ante tantas descripciones y formas de explicar la sociedad cambiante, en este apartado se pretende identificar la estructura de la sociedad colombiana, pero no entendida a partir de procesos de globalización, toda vez que desbordaría la pretensión descriptiva para los efectos de la presente investigación. Para 
ello nos apoyamos en la tesis de LUHMANN (2005) cuando afirmó que "la sociedad debe ser tratada como el entorno social que posibilita y soporta" ( $p$. 85), entonces se describirán los elementos que más consideramos relevantes.

En concordancia con el anterior razonamiento se opta por acoger la técnica de la autopoiesis $\S 1$ pág. 30 empleada por LUHMANN (2005) en su teoría, para poder exponer los elementos que tiene un sistema como lo es el de la sociedad. Basándose en tal método, se entiende que existe una emulación inconsciente en todas las situaciones cotidianas de la vida en donde se crean etiquetas que generan influencia o diferencias entre los propios individuos al interior del mismo sistema, y que de esta leve contradicción el mismo sistema lo toma como referencia de manera transitoria, siendo así como se autoreproduce la sociedad, pero ello no quiere decir que la sociedad misma se adapte a todo lo que recibe.

Ahora bien, la razón de que así se explique la autopoiesis para el análisis de sistemas sociales a partir de la concepción de LUHMANN (2005) permite comprender cómo de manera dinámica se crea movilidad de información al interior del sistema. Por lo mismo se encuentra que, contemplado desde el plano colectivo, en la autopoiesis se percibe una categoría permanente en todo sistema y es el de la comunicación, entendida como ese móvil que permite trasferir información de los conceptos que ella misma considera como vigentes o la facultad de explicar los hechos generadores de nuevas situaciones. 
En realidad lo importante aquí son los procesos de comunicación constantes dentro de la estructura del sistema de la sociedad con otros sub-sistemas en donde se fijan los límites tolerantes que la propia sociedad estima convenientes y, en caso de una trasgresión abrupta se crea una red dirigida al sub-sistema del Derecho en búsqueda de una protección contemplada en los propios códigos. Así pues, es la sociedad la que determina cómo y cuándo cambiar la estructura o los enunciados del sistema.

Ahora bien, pasando a otro tema, examinaremos cómo es que la sociedad se hace sentir en relación a los sub-sistemas de derecho y de la política. Aquí abordaremos el concepto de las necesidades por satisfacer generadas en el curso diario de una sociedad estratificada, la cual no va a esperar tanto las estimaciones a futuro para suplirlas, como sí de la pronta solución en el presente.

A manera de antecedente de las necesidades descrito por BовBIO (2013), se pude encontrar que "desde el momento en que el voto fue ampliado a los analfabetos era inevitable que éstos pidiesen al Estado la creación de escuelas gratuitas, y, por tanto, asumir un gasto que era desconocido para el Estado" (p.43). La trayectoria de las necesidades se fue ampliando hasta el punto que los ciudadanos veían en el Estado un benefactor en donde encontraban "la respuesta a una demanda proveniente de abajo, a una petición, en el sentido pleno de la palabra democrática" (p.43). 
Y quizá ese fue para el político un punto de mayor recolección de votos para ascender al poder bajo la figura de atrapar adeptos bajo el compromiso de garantizar después de ganadas las elecciones una respuesta a las peticiones encontradas pero lo no visto es "la rapidez con la que se presentan las demandas al gobierno por parte de los ciudadanos, contrastada con la lentitud de los complejos procedimientos del sistema político por medio de los cuales la clase política debe tomar las decisiones adecuadas" (BовBIO, 2013, p. 44)

Naturalmente, a lo largo de esta secuencia también la comunicación genera un nuevo efecto: deja de ser una simple forma de exponer una situación particular y concreta de un solo sujeto, pasando a convertirse en un reclamo directo hacia los agentes del Estado para que éstos entren de lleno a buscar una solución a los reclamos recopilados. En la mayoría de los casos dichas exigencias se hacen al sub-sistema político, no obstante cuando ya son muy vulnerables de garantías constitucionales pueden acudir al sub-sistema jurídico y con ello buscar su tutela, lo que parece bastante evidente para SARTORI (2010) cuando considera que "los comportamientos sociales son los que se observan en las instituciones, en las estructuras y en las funciones que componen ese sistema” (p. 218).

Hasta aquí, por lo que a las demandas sociales se refiere, éstas aparecen presentes en todo momento pero son re-descubiertas justamente en los periodos electorales donde se renueva el gobierno que administrará por un periodo constitucional la organización del Estado. Al respecto HeLLER (1996) 
nos hace pensar en algo más concreto, y es en "necesidades reales o irreales" (p. 57). A estos efectos se llega según la autora a la explicación de que las primeras son una manifestación de lo realmente es urgente, mientras las segundas son producto de la imaginación.

Ahora bien, si se pensara en las necesidades reales como producto de una insatisfacción mayoritaria que reclama para sí la sociedad, existen personas determinadas fuera de este grupo de insatisfechos quienes al parecer determinan lo conveniente o inconveniente de esa demanda social. Lo contradictorio de todo esto es que serán los sub-sistemas político o jurídico los que tomarán la decisión de solucionar esa demanda, o de manera simple desvirtuarla.

De lo antedicho, podemos sostener independiente de cómo se miren las necesidades sociales desde el discurso político previo a las elecciones dentro de los dos sistemas democráticos dominantes, esto es, el empírico o el racionalista, será una autoridad a nivel legislativo o administrativo la que realmente tenga facultad no sólo "de distinguir [de manera arbitraria] las necesidades reales de las necesidades imaginarias" (HELLER, 1996, p. 60), sino también la de decidir cómo se puede solucionar dicha reclamación dejando de lado a las personas que, aparte de padecerlas, pertenecen a una colectividad y que según el discurso político en apariencia son las portadoras de la soberanía del mismo Estado. 
En consecuencia, esos factores de decisión arbitraria, tanto para determinar qué es necesario solucionar y qué no, deslegitiman otros sub-sistemas al interior del sistema de la sociedad cuando no son tenidas en cuenta las peticiones colectivas, entre ellos el sub-sistema jurídico, incluso la democracia misma, por cuanto las personas insatisfechas no ven herramientas que el Derecho brinde para garantizarles lo prometido de manera eficaz.

Expuesta esta frustración se encuentra, como es de esperarse, el primer argumento usado como manipulación, dirigido a los despreciados en gobiernos anteriores; esto es, se busca hacer reflexionar al potencial elector que sus puntos de vista sobre lo realmente necesario no ha sido tenido en cuenta por el gobierno de turno, lo cual despierta ese entusiasmo previo a elecciones que se encuentra en cualquier Estado democrático.

Continuando con la importancia de las necesidades sociales cuando justamente se reviven en las elecciones manipuladas por el sub-sistema político, HeLleR (1996) comprendió que "la determinación de las prioridades presupone un sistema de instituciones sociales diferente de aquel que divide las necesidades en reales e irreales" (p. 61). Bajo el anterior argumento, la autora presupone el mejor escenario para que realmente puedan cambiar las cosas este será aquel "debate público democrático" (p. 61). No obstante, al parecer dentro de la sociedad el orden del discurso contradice la proposición anteriormente expuesta, por cuanto en el ejercicio electoral, se atacan las 
políticas del gobierno de turno y a su vez buscan con aparente claridad saber cuál es el la solución sin consultar al propio sujeto padeciente.

A este efecto cabe precisar: cuando estamos en presencia del pleno debate sobre la selección de lo considerado relevante a ser atendido de manera inmediata -necesidades- y lo que no lo es, entra en juego una disputa generada dentro de la misma sociedad y es la confrontación entre las mismas personas por ser escuchadas, lo anterior tiene una explicación a partir de HONNETH (2011), de la siguiente manera: "un miembro de la sociedad solo es integrado en ella gracias a mecanismos de reconocimiento mutuo, pero que estos resultan controvertidos, y por ello, objeto de una lucha por el reconocimiento" (p. 43). Aquí a partir del conflicto entre los mismos ciudadanos por ser escuchados se produce confusión y división al intentar priorizar entre ellos mismos las necesidades, cayendo en la trampa del político quien en últimas decidirá sobre qué tipo de necesidad atenderá según su discurso y conveniencia.

Es en este momento donde la complejidad de la sociedad misma es más evidente, cuando entre tanto desacuerdo llega el sujeto político, inscrito en un partido con reconocimiento público, selecciona de manera arbitraria qué ofrecer como solución a esas necesidades para llegar a ser candidato y así atraer al mayor número de adeptos quienes, a su vez, eligen no convenir entre ellos mismos cómo priorizar sus necesidades y facultan a una sola persona 
para que éste imponga lo que él mismo consideró urgente, como la solución al caso.

Lo curioso es que aquí el sistema social empieza a realizar autopoiesis y genera como anteriormente se expuso dinámicas para contrarrestar los efectos del gobierno de turno quienes no tuvieron en cuenta las consideraciones de los otros, y se empiezan a crear sectores dentro de la misma colectividad que se inscriben en un partido político contradictorio del que ellos nunca han hecho parte, ya no para fijar la existencia de las necesidades y su forma de satisfacción, sino para imponer su propia voluntad en la próxima administración y así cambiar las reglas de gobierno.

Así pues, lo pretendido en un primer momento, como eran las necesidades manifestadas por los mismos ciclos de la sociedad, la misma comunidad de candidatos y electores, éstos últimos impulsados por su constante defraudación, acusan al gobierno de turno imputándole su falta de interés y ahí los grupos interpartidistas se valen de la misma para poder expresar como proyecto en un eventual y próximo procedimiento de elecciones aquella alternativa que sí tendrá en cuenta eso abiertamente ignorado. A este efecto, a primera vista podría ser indicado concebir cómo el ciudadano es motivado por aquella pasión política sin saber que está siendo utilizado para fines personales de la propia política. 
En lo que tiene que ver con la <<pasión política >>, a partir de BENDA (2008) comprendemos que es aquella "voluntad, para un grupo de hombres, de echar mano de un bien temporal: territorios, bienestar material, poder político (...), [esto es] la voluntad, para un grupo de hombres, de sentirse particulares, distintos en relación con otros hombres" (p. 115). Como se ve, el concepto ayuda a justificar cómo es que, dentro de la misma sociedad, un grupo determinado busca sobresalir a los demás por más que exista en la misma Constitución de un Estado una clausura operativa como la del bienestar general, igualdad y preponderancia en lo social.

Lo resultante de todo lo anterior dentro del sistema de la sociedad son los efectos negativos para los demás sub-sistemas -político y de derecho-, los cuales terminan creando categorías influyentes al interior de ellos mismos, y de esta leve contradicción se genera una nueva categoría llamada burocracia, la cual no solo permea las instituciones de Derecho Público, sino que está disfrazada a partir de convenciones que pretenden satisfacer las necesidades como respuesta a lo social, pero únicamente buscan "conseguir bienes materiales para beneficio de su clase" (BENDA, 2008, p. 118).

De lo anterior se puede concluir lo complejo que es la sociedad en cuanto a lectura de necesidades colectivas se refiere; incluso se puede determinar el ímpetu del individuo con fines particulares y más facultades que otros, el cual pretende satisfacer sus intereses personales o de su pequeña red. Con expresiones más o menos figuradas LUHMANN (2005) entiende que "tal vez el 
problema importante reside en las todavía crecientes exigencias en cuanto a la autorrealización individual, ante las cuales parecen fracasar los medios clásicos, liberales, de formación" (p. 645), motivo por el cual, al parecer, el subsistema jurídico ha diseñado algunos mecanismos que pueden servir de paliativo ante esos hechos que en últimas pueden resultar atentatorios de los derechos humanos.

\subsection{EL SUB-SISTEMA DEL DERECHO}

La estructura jurídica, que encierra el sub-sistema del derecho, pretende desde su origen en los Estados modernos, fijar una función completamente diferente a la del sub-sistema político, comoquiera que el sub-sistema del Derecho "produce un efecto propiamente simbólico de legitimación que asegura más sólidamente el mantenimiento del orden social, (MORENO Y RAmíREZ, 2011, p.53). De ahí que desde los primeros orígenes de los propios Estados, ya se hablaba de la existencia de tribunales para resolver conflictos conforme a las formas jurídicas o las costumbres, luego el rol del sub-sistema del derecho, aunque en ocasiones se dejaba influenciar por cuestionamientos políticos, se regulaba atendiendo a operaciones internas a nivel estructural.

Ahora bien, a diferencia de lo que ocurre con el sub-sistema político o el sistema social, la estructura del sub-sistema del derecho "tiene que ser previsible o, al menos, [alguno de sus] instrumento[s] cuyos efectos puedan ser calculados" (LUHMANN, 2005, p. 72). Esto básicamente por cuanto el 
Derecho se muestra ante la sociedad a partir de normas entendidas como aquellas expectativas que pueden llegar a ser o no accionadas mediante dos modalidades: a nombre de quien busca la defensa de sus derechos subjetivos, o por iniciativa de las mismas instituciones como reguladoras de la fuerza.

Con frecuencia se habla que el Derecho puede entenderse a partir de dos premisas, esto es, con la ayuda de Códigos conforme o contrarios a derecho, pero no el código visto como el conjunto de normas creadas por el sistema político y recopiladas por un editor. Aquí el sub-sistema del derecho realiza en apariencia dos operaciones, y en ambas los efectos son predecibles tanto para sancionar como para entrar a garantizar.

Bajo el anterior entendido, uno de los elementos que por la propia descripción del sub-sistema del derecho sobresale es el de $<<$ Norma o ley $>>$, concepto que para el desarrollo de la misma sociedad es necesario tenerlo claro y no confundirlo con una decisión política por una razón fundamental, y es que las normas/leyes imponen límites al sistema social mismo o a los propios subsistemas.

Revelado el primer elemento del sub-sistema del derecho, esto es, la norma, pasamos a un segundo referente y es el de los jueces y cuerpos colegiados magistrados- que son los que a partir del supuesto normativo sentencian soluciones a una controversia conforme a derecho o a las costumbres. Es justamente aquí donde la norma entra en un "proceso de diferenciación" 
(LUHMANN, 2005, p. 359) donde no sólo se vale de los presupuestos consecuencias- que deben tener presente las personas y el mismo Estado como límites o resultados ante su actuar, sino que se tiene que atribuir a alguien la facultad de resolver una tensión.

Ahora bien, algo relevante dentro del sub-sistema del derecho es la expansión a nivel demográfico y la ampliación en redes de comunicación entre otros Estados o comunidades y que a su vez buscan ser reglamentadas mediante leyes o decretos nuevas situaciones, en igual sentido surgen necesidades de justicia o de instituciones que regulen, limiten, solucionen o decidan las controversias; todo esto nos permite concluir siguiendo a (LUHMANN, 2005, p. 366) cuando sostiene: "entre más legislación surge también simultáneamente más competencia judicial", que se esperaría ayude a definir las controversias de cualquier tipo de derecho controvertido.

Es más, si se parte del anterior concepto, debe esperarse entonces ya a nivel de la democracia, tal como se analizó en el sub-sistema político y sistema social que temas como acceso al poder y mandato se encuentren reglamentadas a partir de normas, y a estos efectos debe existir un código en donde no sólo se contemplen las garantías para el ejercicio político; también se espera que dentro de los códigos se hable de procedimientos y derechos en favor de los ciudadanos o en contra del político mismo en torno a las decisiones que puedan tener repercusiones negativas en la sociedad o en una persona particular. 


\section{LA DEMOCRACIA COMO SUB-SISTEMA CREADO A PARTIR DE LA INTERPENETRACIÓN DE LOS OTROS SISTEMAS}

Una vez demostrado cómo se relacionan e interactúan sub-sistemas diferentes, por lo menos en cuanto a la organización descrita en la Constitución de Colombia, esto es, el Estado, la sociedad y el derecho, nos detenemos en el punto central de la investigación, y es justificar el modelo democrático. Hasta aquí, con lo expuesto encontramos y damos por superada la tradición racionalista o empírica que tanta influencia marcó en la teoría de la democracia de GIOVANNI SaRTORI (2007), y nos detenemos en una construcción subsistémica que es la pretendida a explicar.

Previo a iniciar tenemos que recordar una vez explicados los sub-sistemas de manera aislada, política y derecho, así como el sistema social, aquí entraremos de lleno a explicar en cómo justificamos el sub-sistema de la democracia para después contrastar nuestra hipótesis $\S$, pág. 18 cuando critiquemos un gobierno de turno donde podamos verificar si la construcción a nivel teórico subsiste o no por sí misma, es decir, si es un sub-sistema presente dentro de la sociedad o es latente dependiendo de circunstancias de tiempo, modo y lugar, pero cuya función es aberrante toda vez que estamos en presencia de medios de reificación avalados por el propio sub-sistema del derecho. 
Para iniciar, de manera crítica propositiva construiremos la estructura del subsistema de la democracia teniendo en cuenta que quien pretenda llegar al Poder Público Ejecutivo ${ }^{6}$ encuentra dentro del sub-sistema político y del derecho su asidero para lograr sus cometidos, sin embargo requiere además: conocer las reglas internas del sub-sistema político, una legitimación partidista o popular, identificar los procedimientos acordaros para los procesos electorales de ahí que recurra al sub-sistema del derecho para que éste le garantice a partir de códigos las formas de ascenso al poder, y finalmente llegar a la misma sociedad quién decidirá apoyarlo o desvirtuarlo durante el periodo de elecciones.

De esas dinámicas de interacción hoy se puede justificar y encontrar las anteriores explicaciones de los sub-sistemas dentro del sistema social que se ajusta a los fenómenos observables, igualmente podemos afirmar lo siguiente: política, derecho y sociedad contienen unos elementos-origen para justificar el sub-sistema de la democracia. Ahora bien, como dicho acontecimiento no se puede argumentar a partir de simples conjeturas, desde la concepción sistémica de LUHMANN (2005) §1, pág. 24 encontramos elementos orientadores que hacen posible este ejercicio para explicar la democracia según nuestra ruta metodológica.

\footnotetext{
${ }^{6}$ Es de aclarar que no entraremos a debatir las vías de hecho por las cuales se ha visto, como en otros países, sujetos movidos por sus propios cometidos, han llegado al poder público, como por ejemplo a partir de "golpes de Estado" o "guerras bélicas, económicas o ambientales".
} 


\subsection{El SUB-SISTEMA DE LA DEMOCRACIA TOMANDO COMO PUNTO DE PARTIDA LA INTERPENETRACIÓN}

En relación a cómo surge lo que llamamos democracia, a nivel de la teoría sistémica y sus lineamientos generales nos apoyaremos en la “interpenetración de los sistemas" (LUHMANN, 2009), en donde, aunque existen marcadas diferencias entre sub-sistemas, cada una de éstos deja que un nuevo sistema o sub-sistema se relacionen entre sí y pueda obtener lo necesario para construir su propia estructura. Por su parte, los primeros subsistemas "pueden tener una significación [o influencia sobre lo nuevo que está surgiendo en] mayor o menor [escala]" (p. 116) frente a ese nuevo fenómeno sub-sistémico, el cual no se crea de manera autónoma; sobre él recaerán limitaciones por la misma información que recibió para nacer, en otras palabras, "nunca producen efectos sin la con-casualidad de las estructuras y procesos de sistema influenciado y están en este sentido, sujetos a [los] límites de lo posible" (LUHMANN, 1980, p. 117).

Basándonos en la anterior explicación podemos justificar ahora por qué dentro del naciente sub-sistema de la democracia, el sub-sistema político juega un papel importante cuando sus integrantes aspiran a tener acceso a un cargo de elección popular, pero aún más, cómo es que el sub-sistema del derecho brinda protocolos normativos de legitimación para acceder al poder público, 
incluso la forma en que sus decisiones después de posesionado en el cargo tendrán fuerza vinculante con efectos a terceras personas o restricciones a los integrantes de la misma sociedad.

Ahora bien, procuraremos evitar algún tipo de señalamiento si por ejemplo se sostuviera que dicha explicación no es novedosa, por cuanto desde siempre ha sucedido lo mismo pero con justificaciones diferentes. Empero, para intentar contrastar eventualmente ese tipo de formulaciones, nos importaremos una categoría que nos puede ayudar a completar la descripción prescrita, y es la de las acciones entendidas como "elementos (acontecimientos) temporalizados con diferentes pasados y futuros, dependiendo del sistema" (LUHMANN, 1980, p. 118).

En otras palabras, <<las acciones >> con que se justificaba la democracia en las distintas épocas no son hoy las mismas, como tampoco lo serán hacia un futuro, por cuanto, así como la interpenetración mediante procesos diferenciados de acción facilitó que el sub-sistema de la democracia recibiera elementos de los sub-sistemas de la política, y del derecho sin olvidar lo propio del sistema social cuyo aporte se encuentra en la movilidad ciudadana en procesos de elecciones donde no sólo existe decisión de sufragar sino abstención, puede un día cambiar el estado de cosas y depender la democracia de compromisos económicos o de acuerdos transnacionales y suprimirse o modificarse alguno de los anteriores elementos que hoy conforman la estructura de la democracia. 
Es en este punto donde llegamos a empatar la importancia de la democracia dentro de la órbita funcional del Derecho Público a partir de la acción, porque es aquí cuando la democracia se ha valido de una serie de premisas jurídicas para no solo justificar que el acceso al poder sea reglamentado, sino que ha existido en algunas épocas de la historia donde la sociedad se ha visto reivindicada y se le han puesto exigencias al sistema político a partir de lo jurídico. Por eso encontramos hoy premisas como mandato al gobernante, cláusulas de interés general, responsabilidad derivada de los actos $u$ omisiones del dirigente, el régimen disciplinario de los funcionarios públicos, entre otras reglas jurídicas que en la mayoría de los casos encontramos en códigos conforme o contrarios a derecho, cuyos efectos son predecibles tanto para sancionar como para entrar a exigir la conducta del dirigente político.

Sin embargo, con las mismas premisas de los sub-sistemas político y jurídico, respetados autores de la democracia entre los siglos XX e inicios del XXI también han encontrado durante sus épocas otras acciones que la misma democracia ha recibido y de las cuales todavía no se ha podido deshacer; una de ellas es la burocracia. Ya en sus escritos Bоввı (1986) vislumbraba la existencia análoga de los procesos burocráticos como una consecuencia de la democracia, tanto así que lo veía como un obstáculo cuando sostenía que "todos los Estados que se han vuelto más democráticos se han vuelto a su [vez] más burocráticos, porque el proceso de burocratización ha sido en gran parte una consecuencia del proceso de democratización" (p. 27). 
Otros, por su parte, y continuando con las determinadas lecturas 0 experiencias vividas, han encontrado al interior de la democracia acciones autoritarias como por ejemplo O'DONNEL (2009), quien primero entiende que para llegar a constituirse un Estado Burocrático Autoritario (BA) se ha tenido que pasar por una serie de acontecimientos en donde "en el periodo de eclosión de lo popular, la ciudadanía quedó ligada al debate sobre las formas oligárquicas de la democracia política, restringida y trampeada" (p. 26).

Lo sucedido para el profesor argentino con su anterior postura constituyen los requisitos previos para la construcción de un (BA), los cuales pueden resumirse en tres: "la eclosión de lo popular como principal contenido de la nación, (...) las restricciones resultantes de una estructura productiva que acentuaba sus características económica y socialmente desiguales, así como desbordantes del ámbito presupuesto por la pretensión nacional del Estado" (O'DONNELL, 2009, p. 35). Sin embargo, tenemos la sospecha que si atendemos la explicación de la interpenetración sistémica observamos que en efecto esos elementos se desprenden de otros sub-sistemas como el político, económico incluso del mismo sistema social.

Otro, elemento que salta a la vista es el concepto del contrato social presente cuando hablamos de una metáfora filosófica, en donde una colectividad elige y pone en cabeza de alguien determinado la facultad para tomar decisiones en nombre de una nación o territorio. Aquí, nosotros comprendemos que el contrato social, por así decirlo, es un elemento de relevancia para el sub- 
sistema democrático, entonces consideramos oportuno entrar en su estudio para determinar sus presupuestos y alcance teórico.

Para abordar el tema recordaremos lo anotado por PINKER (2012), el cual encontró que las primeras manifestaciones del contrato social no se pudieron provocar antes de HOBBES (2005) o en las primeras civilizaciones, en razón a que "los primeros [E]stados eran algo parecidos a «tinglados» de protección, en los que los poderosos mafiosos sustraían recursos a los habitantes, a quienes ofrecían a cambio seguridad individual frente a vecinos hostiles" ( $p$. 79). Así pues, fue con el Leviatán la manera más aproximada donde los ciudadanos bajo unas cláusulas restrictivas de sus bienes y de su libertad podían vivir mejor, y así sentir "que sus leyes, la imposición de las mismas y otras disposiciones sociales son legítimas [y exigibles]" (PINKER, 2012) para conservar la convivencia pacífica.

Aquí no vamos a partir de los primeros acercamientos vislumbrados en (HOBBES, 1651) y su alternativa de intentar un orden social que acabara con la violencia traducida como ese estado natural, o examinar a profundidad de cuanto aquí se ha dicho frente a ese tema, puesto que existe un intento algo más moderno expuesto por BOAVENTURA DE SOUSA SANTOS (2004) y su noción contractual reciente planteada en su obra Reinventar la democracia, reinventar el Estado, donde inicia diciendo que "el contrato social es el meta-relato sobre el que se asienta la moderna obligación política" (p. 1). 
Bajo la anterior concepción es importante revisar a continuación qué tan orientadores o criticables pueden ser las apreciaciones de SANTOS (2004), para lo cual abordaremos, en su orden: la antigua concepción que se tenía del contrato social, expuesta por SANTOS (2004), y a renglón seguido exponer la alternativa descriptiva propuesta por el mismo autor. Planteado así, tenemos que el contrato social posee tres elementos de exclusión: "el primero se sigue del hecho de que el contrato social sólo incluye a los individuos y a sus asociaciones; la naturaleza queda excluida" (SANTOS, 2004, p. 2); como segundo elemento se encuentra: "sólo los ciudadanos son parte del contrato social" (p. 2), y finalmente, "solo los intereses que puedan expresarse en la sociedad civil son objeto del contrato" (p. 2).

Antes de continuar con dichos elementos presentes en el contrato social y los nuevos que se derivarán actualizándolos a la sorprendente modernidad, encontramos un concepto que no pasó por inadvertido para la investigación, y creemos que tampoco para el propio SANTOS (2004), cuando antepone en el contrato social una premisa de exclusión. Aquí nos valdremos de esta noción para emprender un análisis un tanto más específico de dicho elemento, y así llegar a determinar la función misma de la democracia. 


\subsection{El desprecio etiquetado como resultado del Proceso DEMOCRÁTICO}

Una vez expuesta la estructura del sub-sistema de la democracia, consideramos oportuno detenernos en su función a partir de la cual algún efecto debe tener en el sistema social. Para ello consideramos oportunas las dos elaboraciones teóricas que pueden describir el estado de cosas que dejan los actuales ejercicios democráticos después de terminadas las elecciones.

Primero nos valemos de la teoría sobre el desprecio trabajada por AXEL HONNETH (2005), quien observa que los individuos movidos por sus deseos de lograr sus estilos de vida personales se terminan explotando entre sí para lograr satisfacer sus cometidos. Para describir este fenómeno HONNETH decidió emplear el concepto de reificación, en donde las personas se cosifican dependiendo de distintos propósitos sin importar que en el proceso unos se valieran de los otros hasta lograr sus intereses. En cualquier caso, resulta que el individuo se encuentra tan inmerso en sus propias ambiciones que todo lo que suceda a su alrededor, lo tiene sin cuidado incluyendo los asuntos de la esfera del Estado.

Aunque en HONNETH (2005) el ser humano termina siendo un objeto más de otro sujeto, el individuo no se desarrolla tan fácilmente debido a sus propias necesidades, siendo esto una limitante para lograr sus cometidos. Entonces, 
existe un sentimiento de querer substraer a los otros lo que falte para sí mismo. Dicho proceso se realiza mediante la interacción entre sujetos en donde uno de ellos aprovecha la situación del otro para sus propósitos particulares.

Pero como lo dicho no se desarrolla bajo el silogismo jurídico, en donde $X$ atenta contra los bienes jurídicamente tutelados de $Y$, existiendo una consecuencia jurídica y un reproche social, la explicación aquí para demostrar cómo se convierte a un sujeto en un objeto es completamente distinta. Primero, el interesado tiene que buscar ser reconocido por el sujeto al cual va a utilizar; así pues, la reificación se vuelve no sólo un pensamiento proyectado en la búsqueda de un provecho, sino que se convierte en un hábito seguido por todos y el cual se encuentra inmerso tanto en la realidad vivida como la observable en distintos sub-sistemas sociales.

Así las cosas y haciendo extracción de lo expuesto, se requiere de una relación de reconocimiento recíproco en dicha relación que produce efectos cosificados. Hasta aquí pareciera que existe una idea latente: la reificación se encuentra presente dentro de la sociedad, tal como de manera acertada lo expuso LUHMANN (2009), cuando al pretender dar una explicación del origen de la sociología y sus avances comprendió que "en lo que concierne a la dimensión social, cualquier otro hombre siempre es sólo un objeto para el sujeto (...) Esto es necesaria e inevitablemente así, dado que el otro hombre siempre es sólo un objeto para el sujeto" (p. 70). 
En este proceso no interfieren juegos dialécticos sino que cada uno sabe para qué utiliza al otro, y pueda que éste no lo sepa de la misma manera, pero es esa comunicación la que motiva cualquier actuación futura, entonces, "la subjetividad del sujeto formula una realidad que es accesible inmediatamente para cualquiera" (p. 70). De esto se sigue que "el sujeto es fórmula de inclusión par excellence. Dentro del nuevo orden social no tiene ningún lugar fijo y, por tanto, no puede esperar una «vida buena»" (LUHMANN, 2009, p. 71).

De la misma dinámica expuesta, la podemos acoplar a la función del subsistema de la democracia, esto es, al necesitar la democracia indiscutiblemente de los sub-sistemas político, del derecho con asiento en el propio sistema social, para existir dentro de una realidad observable, quien pertenezca a la política tiene que usar a tantos aquellos del sistema social que necesite para lograr acceder al poder, por más que en el sub-sistema del derecho predique principios constitucionales de interés general.

Con ello encontramos a nivel teórico que el sub-sistema de la democracia $<<$ reifica > al mismo sistema social, en especial al ciudadano-elector durante cada procedimiento electoral, usando de manera directa a todos aquellos que en apariencia legitiman el discurso democrático en lo que tiene que ver con la dirección del Poder Ejecutivo. Ahora bien, analizada la función de la democracia en cuanto apunta a procesos de reificación, un obstáculo sobresale a la vista: qué paso con las necesidades que ese candidato garantizó atender, porque al parecer el elector ejerció su "poder de decisión 
electoral" para que en aras de la democracia representativa pudieran ser oídos los clamores de tanta urgencia social.

Un argumento que ya ha sido tratado y que refuerza nuestra hipótesis de reificación es lo expuesto por GALLI (2013) en su obra el malestar de la democracia, cuando encuentra en los aportes de la escuela de Frankfort cómo se reduce el individuo a una masificación donde los poderes públicos se convierten en determinadores de los lazos funcionales de lo que se debe hacer y el individuo pierde esa soberanía de ser escuchado y atendido (p.54).

Al parecer las necesidades jamás serán escuchadas si los reificados no emprenden a abrigarse en movimientos políticos que tengan influencia o una marcada posición interpartidista y así lograr el contrapeso a quien los ignoró, esperando entonces los próximos comicios para que exista alguien dentro del sub-sistema político que sí los represente ${ }^{7}$. Es por ello que "los modos de representación de sentimientos sociales de injusticia no están libremente a disposición de los sujetos afectados (...), sino que están influidos y codeterminados por los múltiples mecanismos de dominio de clases" (HONNETH, 2011, p. 64). Algo muy parecido a cómo se determinan las propias necesidades sociales según HELLER (1996)

\footnotetext{
${ }^{7}$ Este fenómeno se va convirtiendo con el tiempo en cíclico y al parecer es como la democracia se mueve por nuestros días. Tal como lo explicamos en el primer capítulo, en las dinámicas explicadas dentro de la estructura del sub-sistema político.
} 
Así las cosas, no queda más camino que padecer el olvido del propio Estado y restarle importancia a lo acontecido, en otras palabras, no es vivir por vivir sino esperar que algún día exista una reivindicación a tantas reclamaciones, y como no llega, o mejor, como siguen percibiendo que son reificados por el subsistema de la democracia sin responsabilidad política que el sub-sistema del derecho pueda imputar, dejan de lado sus esperanzas y continúan sus vidas sin más reparo, con promesas que jamás llegarán y lo que se consideraba urgente ya quizá se convierte en habitual no tenerlo.

Ahora bien, cuando indagamos sobre la postura del sub-sistema político frente a aquello que eventualmente los legitimó para acceder al poder <<las necesidades sociales >> y su respuesta a por qué no lograron cumplir esas expectativas de sus promesas encontramos frecuentemente dos respuestas, la primera consiste en la dificultad encontrada con los conflictos interpartidistas -oposición- y que para solucionar las diferencias, el que prometió se convierte en empresario para vender la idea a la bancada opositora y éstos se muestran como negociadores dispuestos a dar su aprobación siempre que exista una contraprestación o beneficio para sus grupos de interés más no a sus representados pero como la mayoría de las veces no logran negociar, justamente los temas de alto impacto o cambio para la sociedad en general no se cumplen.

Otra manera de excusar la imposibilidad de cumplir las demandas sociales se encuentra en la justificación técnica que dan los expertos de ahí que BoBBıo 
(2013) entienda que "los problemas técnicos necesitan de expertos, de un conjunto cada vez más grande de personal especializado" (p.41), y como la mayoría de las necesidades tienen un trasfondo técnico empezando por el presupuestal, una promesa política que asegura atender una necesidad tiene como condicional para ser atendida un aval tecnocrático. De ahí que "los regímenes democráticos se caracterizan por una desproporción creciente entre el número de demandas que provienen de la sociedad civil y la capacidad de respuesta del sistema político". (BоBBIO 2013, p.104)

Finalmente, cuando ya se afirma lo anterior como parte de la respuesta al problema de investigación, por lo menos a nivel dogmático, podemos emplear unos argumentos usados en la ciencia médica para explicar por qué el individuo experimenta cambios en su memoria a corto y largo plazo, donde recuerda más los episodios de sensibilización ${ }^{8}$ que los de habituación ${ }^{9}$, en lo que tiene que ver con las promesas rotas de los procesos electorales pasados por parte del sub-sistema político ante las necesidades que prometió resolver.

En lo que a la $<<$ habituación $>>$ se refiere, ésta se da cuando la persona no tiene interés por lo que presencia: "el sujeto aprende a pasarlo por alto lo que implica una disminución de la respuesta neuronal al estímulo" (KANDEL, 2008,

${ }^{8}$ Es una forma de aprendizaje asociada a fenómenos directos, pero cuya experimentación repercute en reacciones-reflejo, que en el tema de la democracia se ve reflejado en esa reacción por no votar al ya haber vivido sensaciones pasadas donde no sacaron nada bueno de ir a sufragar por alguien que no les cumplió.

${ }^{9}$ El sujeto permanece atento a sensaciones, furor, pasión, ira, indignación, pero lo pasa por alto después, ello implicaría un desinterés a sus percepciones después de la efervescencia de sus emociones. 
p. 497), entonces, cuando en el ejercicio electoral llegan políticos a prometer la "salvación" a sus necesidades, o cuando observan catástrofes al interior de la administración pública, tales como desfalcos económicos, trasgresiones a los derechos humanos, entre otros, pareciera que nada le inmutara al oyente dejando de lado lo escuchado y continuando con su acostumbrada vida.

En cambio la sensibilización se da a partir de "un estímulo nocivo que genera una respuesta refleja más intensa a otros estímulos, incluso a los inocuos" (KANDEL, 2008, p. 503). Ello lo podemos corroborar cuando es tanta la contundencia de una situación, como por ejemplo la del futbol nacional, que el hincha sale a exponer su reacción a las calles, cosa que no ocurre al interior del sub-sistema de la democracia cuando no se reconfigura nada nuevo, sino las mismas promesas pero con diferentes actores.

Lo anterior, a nivel teórico termina convirtiéndose en el ciudadano en un hábito, esto es, "a medida que las experiencias concretas y puntuales se repiten, se acumulan las huellas que cada una de ellas va dejando, se superponen, se combinan, se refuerzan interiorizándose cada vez más profundamente, y se transforman en disposiciones generales" (MORENO Y RAMÍREZ, 2003, p.19); de ahí que sea usual encontrar el desinterés de los ciudadanos en épocas electorales y finalizadas los comicios, ya no se interesen por lo político.

La excepción sería buena poderla exponer, pero hasta el momento no se encontró que al interior del sub-sistema de la democracia se hable de algo que 
haga movilizar las emociones de una comunidad y que trascienda no sólo en la memoria a largo plazo, sino que esa efervescencia sea motivo para hacer exigir una solución efectiva y real a sus necesidades; como máximo se habla de fervores brotes de populismo, pero muchas veces emulado o pagado por algún partido político para irse en contra de otro, en otras palabras, lucha interpartidista al interior del sub-sistema de la política.

Hasta aquí encontramos que en el primer aspecto, a manera de crítica, "«los individuos por destino» (...) no se suman a una causa común" (BECKGeRNSHEIM, 2003, p. 23); así las cosas, es bastante difícil poder sostener la afirmación de que un contrato social intenta vincular en una democracia a todos los individuos o sus asociaciones, por lo mismo que a partir de su experiencia, y de los episodios almacenados en su memoria "el individuo tiende a desentenderse, a ser escéptico o precavido respecto del «bien común», de la «buena sociedad» o de la «sociedad justa»" (p. 24).

\subsection{EL CONTRATO/MANDATO}

Retomando lo expuesto en lo que tiene que ver con el mandato mismo, ya habíamos entendido en una primera parte que la noción del contrato abarcaba elementos tales como: la preponderancia del individuo, sólo los ciudadanos hacen parte del contrato, y los intereses comunes que puedan cubrir a muchas personas serán aquellos tenidos en cuenta. A partir de ahí no cabe duda que 
un contrato con tales características no es que llegue a ser muy "social", comoquiera que, incluso las necesidades de la sociedad son fijadas de manera arbitraria, así pues, la expresión de TUGENDHAT (1997) es muy acertada cuando señala que "el contractualismo es, de esta manera, una posición mínima y que existe legítimamente, sólo que no llega muy lejos" (p. 75), y no llega porque una cosa es el discurso jurídico y otra su proyección por parte del sub-sistema de la política en donde ya explicamos cómo es que se cosifica a toda una colectividad que hace uso del sufragio para elegir a un gobernante.

Otras cuestiones se plantean en torno a la figura del mandato, pero que inician desde la manera de concebir el voto. Por lo mismo que el sufragio al ser considerado universal pero secreto, la óptica del mandato sufre con ello cambios dado que si antes, bajo el principio de la representación las urnas se convertían en el espacio para elegir entre potenciales candidatos, lo oculto de la elección hace que "el ciudadano que vota se sienta aislado en el momento decisivo" (SCHMITT, 2011, p.316)

Además de esa suma de votos donde ganará el que tenga la mayoría exigida, el mandato se rompe porque no se tiene claridad de quién voto por éste 0 aquel político siendo ello punto de quiebre para hacerlo exigible, además los vencidos en el proceso electoral y sus votantes sin pensarlo, se adhieren automáticamente bajo el enunciado de representación de toda la sociedad. Es decir, "el diputado por estar ligado a la voluntad eventual de sus electores, no dependería de la voluntad de todo el pueblo, sino de la voluntad de una parte 
de los ciudadanos con derecho al voto" (ScHMITT, 2011, p.338). Pero todo eso se disuelve y empieza a gobernar un agente político que ya se encuentra legitimado para decidir y el "mandato" se considera una retórica filosófica poco acorde a la realidad.

La importancia del mandato en épocas anteriores ayudo a hoy tener un sinfín de derechos subjetivos que a la postre permiten un avance en la historia de los derechos fundamentales tal como lo sostiene GaLLI (2013): "en efecto, fue a través del estado representativo que el individuo, como ciudadano, pudo exigir que se hicieran realidad en la práctica sus derechos" (p.36). Sin embargo, en un capítulo que el propio profesor italiano denominó las contradicciones de la democracia concluyo algo contrario a su primer enunciado "la teoría de la democracia moderna constituye una mistificación (no existe un pueblo como universal real que deba ser representado) y, por otra, es imposible (...) que la democracia sea inmediatamente el gobierno del pueblo" (p.50).

Por eso, las apreciaciones de BoBBıO (2013) nos acercan más a esa tendencia de la propia democracia donde "los ciudadanos electores investidos -en cuanto electores- de una función pública, se vuelven clientes, así la relación de naturaleza pública se transforma en una relación de naturaleza privada. ( $p$. 154). De esta manera todos los esfuerzos por separar el contrato social de las bases mismas del derecho civil en cuanto relación comercial, tienen sentido cuando arriba indicamos con WEBER (1995) §1 pág. 54 no sólo la forma en que 
el político vive de la democracia sino cómo recibe utilidades o entrega prebendas.

En definitiva, el mandato o contrato es fácilmente manipulado desde la esfera misma del sub-sistema de la democracia, por parte del gobernante quien emplea sus estrategias traídas del sub-sistema político, es por ello que "el contractualismo contiene especialmente también un sentido válido de justificación $-(\ldots)$, [principalmente para el político] o al menos [cuando aparenta] someterse a él (...)-" (TUGENDHAT, 1997, p. 75), en el entendido de que se valdrá de ese mandato para legitimar sus decisiones así como también aferrarse al cargo para evitar ser derrocado o revocado, y esto será lo que nos proponemos demostrar en el último capítulo de la investigación.

Ahora bien, explicada la manipulación que tiene el propio contrato/mandato, nos concentramos en la propuesta que hace BOAVENTURA DE SOUSA SANTOS (2004) al universo contractual. Como primera medida y para suplir la exclusión ya tratada, hablamos de algo ya visto en el sub-sistema de la política, en donde los ignorados por el gobierno de turno, cuando les llegue su momento, ascienden al poder para poner sus reglas, entonces los procesos de inclusión/exclusión serán necesarios en el modelo que hoy tenemos y de manera difícil puede dicho aspecto cambiar, salvo que se nos ocurra otro modelo que reemplace el democrático, que no sea los anteriores ya vistos en la evolución de la comunidad mundial ni mezclándolos entre sí. 
Para intentar hacer una correlación con SANTOS (2004) el autor nos expone que se debe procurar en el nuevo contrato social "un régimen general de valores" (p. 3), pero como sucede en el caso del sub-sistema del derecho, cuando intenta desarrollar la idea de los valores dichos preceptos nacen de la misma Constitución ${ }^{10}$ y son los que el poder legislativo -sub-sistema políticotiene que empezar a desarrollar ${ }^{11}$, pero aquí no tanto se peca por exceso como sí por buenos intereses, toda vez que de los resultados de vivir cosificados, los valores aquí pierden la importancia; más bien se ve con frecuencia que dichos postulados son recalcados en los fallos judiciales en lo que a protección de derechos fundamentales se refiere, cuando el juez de tutela exhorta justamente a que las actuaciones del Estado deben velar por la protección a la comunidad y procurar el bien común. Así las cosas y expresado correctamente, un contrato/mandato que tenga como propósitos lo que BOAVENTURA (2004) expone, es algo místico.

Continuando con lo anterior, y como segunda medida, encontramos una alternativa que aboga por la existencia de un "sistema común de medidas [en donde] se definen las diferencias relevantes" (SANTOS, 2004, p. 3). Frente a lo anterior, podría pensarse en una forma de conciliación de las necesidades donde ya no sea una clase plenamente dominante la que decida qué se va

\footnotetext{
10 Por lo menos en Colombia gracias su forma de Estado y su organización contemplada en la Constitución de 1991.

${ }^{11} \mathrm{La}$ anterior noción se extrae de lo preceptuado en la sentencia T-406 de junio 5 de 1992 MP. Ciro Angarita Barón, cuando se refiere a la estructura del Estado Social de Derecho, en especial, hace mención de lo que son los principios y los valores en Colombia donde éstos son desarrollados por el Legislador.
} 
atender y su justificación, sino sentarse y entre las distintas formas que el propio sistema capitalista mundial admita, encontrar cuál es la que más puede permitir una armoniosa salida a un malestar de urgencias que encierre a toda una comunidad.

No obstante de los buenos propósitos que SANTOS (2004) expone, a la luz de tantas prevenciones justificadas que tiene el individuo, consideramos complejo que exista una auto-referencia de las necesidades, por lo mismo que cada individuo experimenta estados de necesidad y cosificación completamente diferentes a los de un grupo. Aquí es donde se debe apostar por suprimir que es la mayoría dentro de una democracia la que tiene la razón. Más bien, y expresado correctamente, es dentro de dicho proceso donde el político intenta sacar el mayor beneficio atrapando el mayor número de adeptos, proponiendo fórmulas que si bien no atienden por completo dicha necesidad, a lo sumo la distrae o a la inversa, declara culpables a los dirigentes del pasado por no prestar atención a dicho flagelo.

Continuando con lo antedicho, encontramos una tercera razón como propuesta para mejorar ese contrato/mandato, y es la de crear espacios para fijar "un régimen de pertenencia [donde se legitime] la normatividad que sirve de referencia a todas las relaciones sociales" (SANTOS, 2004, p. 5). Entendemos que el núcleo básico de esta idea es la facultad de socializar los proyectos propuestos dentro de la campaña electoral, pero agregaríamos la posibilidad de que a su vez se puedan hacer exigibles. De hecho, esa podría 
ser la idea que subyace y la cual permitiría que los ciudadanos insatisfechos puedan hacer exigible esa frustración a las expectativas que ellos aceptaron viables de realizar.

Aquí se juega ese aspecto psicológico anteriormente nombrado, y es que la memoria a nivel del sujeto alcanza a recordar una vez empiece a transcurrir el mandato: qué tanto se prometió el gobernante con arreglo a su gestión y cómo lo ha cumplido, pero también se debe a lo siguiente: por lo mismo que la democracia es un sub-sistema que aparece únicamente para el proceso de las elecciones, al momento de existir socialización de algún tipo, nadie se muestra interesado salvo los mismos integrantes del sub-sistema de la política que bien, o pertenecen a la espera que detenta el poder, o los opositores, quienes como se espera, refutarán o intentarán hacer ver como dicha gestión no cumplió con lo prometido, pero aquí aclaramos: la oposición no representa ese porcentaje electoral que sufragó ni tampoco la totalidad de la sociedad se haría presente por una sencilla razón, deben buscar la manera de atender sus propias necesidades.

Las razones que nos llevan a sacar las anteriores deducciones se basan en los estudios previos de la estructura y función misma tanto de la sociedad como de la política, agregando ese toque cosificado que la misma democracia arroja dentro de su función, más aún cuando se crea esa habituación entendida como un completo desentendimiento por lo público, cuya justificación proponemos se da por la misma razón que se sienten unos sujetos 
desplazados y otros utilizados; el resultado sin perderlo de vista sigue siendo el mismo, las necesidades no se atacan, se intentan proponer paliativos que a la final terminan inconclusos si se contrasta con la razón encomendada o la prometida antes de los escrutinios.

En cuanto a las apreciaciones examinadas de lo que un contrato moderno puede tener, SANTOS (2004) le agrega características tales como "legitimidad del gobierno, bienestar económico y social, seguridad e integridad colectiva" (p. 6). En este sentido entendemos que se tienen lecturas completamente distintas en cuanto a la forma de concebir el contrato, toda vez que, a partir de nuestra lectura estructural funcional, no hay cómo exigir ni siquiera con la fuerza del sub-sistema del derecho. Así mismo, al existir un chip de desprecio en la sociedad, un contrato-mandato, teniendo en cuenta la habituación reflejada en el desinterés de lo público, será un mecanismo de poca credibilidad para el ciudadano-elector, pero muy llamativo para el político, porque sobre dicha dinámica se planean la mayoría de las promesas electorales.

Hasta aquí a nivel dogmático podemos concluir que al haber descrito la estructura de la democracia, con fundamento en los sub-sistemas político y del derecho, tomando como base el sistema social, surgen una serie de resultados que en un primer plano rompen con lo místico de la institución, por tanto no podemos volver al pensamiento congelado donde se afirmaba que el poder se encontraba en manos del pueblo tomando como etimología la palabra 
figurada; tampoco podemos afirmar lo que ARENDT (1993) entendía en la política para la Edad Moderna, esto es, donde "lo político únicamente vale como medio para proteger la subsistencia de la sociedad y [la] productividad del libre desarrollo social” (p. 63), toda vez que ya advertimos la cosificación sobre el elector.

En un segundo plano concebimos que la función de la democracia no es aquella donde las decisiones vinculan el bienestar general y mucho menos ayudan a la solución de necesidades colectivas, comoquiera que aunque se encuentren muchas angustias sociales, e incluso personales, es una clase social distinta a la que padece la urgencia, quien decide cómo se va a atender ésta y desde qué óptica, limitando no sólo la voluntad de los demás sino creando un monopolio de decisiones que vinculan a todos. Entonces, la función de la democracia genera reificación en dos niveles: I) en cada periodo de elecciones donde se usa al ciudadano para legitimar la estadía en un cargo de nombramiento popular, y ii) para propósitos personales del político o de su esfera burocrática partidista o económica.

Como tercer plano entendemos que no se vive en democracia por lo expuesto en la parte dogmática; lo que hay es una dinámica de interpenetración de otros sub-sistemas, los cuales le dan vida al sub-sistema mismo de la democracia únicamente por breves espacios de tiempo, como son los periodos para elegir funcionarios en representación de la voluntad social, y por más que se promocione la enseñanza de la democracia en colegios, universidades, 
corporaciones, entre otros, la esencia de la democracia es vista como un procedimiento para legitimar a quien está en la cabeza de una organización, más no todas las decisiones son puestas en conocimiento de la colectividad ni mucho menos las promesas son tomadas con seriedad, por lo mismo de aquellos acuerdos políticos pueden pesar más que las mismas promesas realizadas al elector.

Finalmente, aunque se habló de la figura del mandato/contrato para obligar al gobernante, y expuestas sus deficiencias, se tiene además que cuando el subsistema democrático permite al político en su excurso asumir "pactos sociales y compromisos anteriormente asumidos que (...) [son] imposible[s] cumplir, cuando, de hecho, la situación anterior nunca pasó de ser un contrato-promesa y unos pre-compromisos que, en realidad, nunca se llevaron a cabo" (SANTOS, 2001), esa inclinación de prometer sobre los mismos temas debería generar algún tipo de responsabilidad ante los electores.

Resalta aún más la complejidad saber que ninguno de los sub-sistemas político o del derecho, incluso el propio sistema social ha logrado dar respuesta a las anteriores críticas formuladas anteriormente, sin agregarle un nuevo hecho dentro de la sociedad y es la aparición de pequeñas redes de comunicación sin regulación alguna, que son las que deciden a partir de técnicas de investigación de mercado una buena o mala gestión dentro de un gobierno, incluso se atreven a medir el grado de satisfacción o insatisfacción de las personas con "estadísticas a un pequeño sector de la población civil - 
muestreo-" las cuales con la influencia de los medios masivos de radio, prensa, redes sociales y televisión en trasmitir cifras o información generando dos problemáticas: deslegitimar el gobierno o mostrarlo eficiente, y provocar sensaciones de desinterés colectivo con un fuerte desprecio hacia lo público.

Una vez finalizada esta primera parte de la investigación validaremos nuestra hipótesis contrastándola con un hecho real, y es el estudio tanto de la legislación y pronunciamientos judiciales como de autoridades que por su competencia funcional han tenido que ver con la democracia. Para ello nos adentramos en la segunda parte, con una mirada sobre el propio sub-sistema político nacional para encontrar si algunos de los elementos anteriormente descritos a nivel teórico pueden ser percatados; de igual manera examinaremos, la legislación colombiana en lo que a premisas democráticas se refiere, en especial el tema del voto programático, las leyes que lo reglamentan, las decisiones de la Corte Constitucional frente a sentencias de constitucionalidad, como también algunos fallos de tutela que tienen que ver con el tema propuesto para finalizar con una lectura político jurídica vivida en la circunscripción electoral de la capital del país. 


\section{CAPÍTULO II}

\section{PERSPECTIVA DE LA DEMOCRACIA EN COLOMBIA}

\section{EL VOTO PROGRAMÁTICO EN COLOMBIA}

No podemos negarnos a la realidad que dentro de un sistema jurídico existan leyes que refuercen aquellos ideales o principios políticos puestos prima facie dentro de la Constitución, y sobre los cuales la figura de la "democracia" es vista como esa idea político-normativa mediante la cual "el pueblo expresa su máxima voluntad", pero no la voluntad de ver gobernadas sus vidas, sino de elegir a quien ellos creen puede manejar la Administración Pública y disponer del presupuesto establecido para un territorio, gravar en impuestos o crear desarrollo.

Aquí ya entraremos de lleno a intentar exponer la democracia dentro de un Estado social de derecho, ubicándonos en un país como Colombia, pero más específicamente estudiaremos una particularidad de la democracia, esto es, el voto programático, y la razón que nos lleva a explorar dicha temática y no otra ${ }^{12}$ es quizá porque la propia Asamblea Nacional Constituyente vio en este instituto la renovación de la democracia en donde existen consecuencias para el gobernante incumplido y herramientas como la revocatoria del mandato para

12 Como por ejemplo el voto, el plebiscito, el referendo, la consulta popular, el cabildo abierto y la iniciativa legislativa (Constitución, art. 103). 
los ciudadanos que no sientan satisfechas esas promesas que les hicieron en época electoral.

No abordaremos esa temática sin antes plantearnos los problemas políticos y cuya influencia notoria nos traen a nuestro presente "mejores ideales de democracia" como los expondremos tomando la propia Constitución de 1991 como referencia, a renglón seguido exploraremos las leyes que regulan el ejercicio del voto programático incluyendo el procedimiento para revocar el mandato, como también las decisiones tanto judiciales como administrativas sobre la materia. Después, nos detendremos en un caso particular donde esperaremos integrar las tendencias de la democracia descritas a nivel teórico y su aplicación a partir de un contexto con hechos tanto políticos como jurídicos, sin olvidar claro está el componente social observado desde el subsistema de la democracia. Finalmente terminaremos la investigación con las conclusiones y sus indicadores.

\subsection{LOS PROBLEMAS POLÍTICOS DEL PASADO Y DEL MOMENTO PRESENTE}

Teniendo en cuenta a partir de las nociones sistémicas que los hechos del pasado no siempre sirven de referente para determinar una situación presente por lo menos en cuanto a la autorreferencia se trata §1 pág. 28, encontramos dentro del sub-sistema de la política unos elementos que no siempre se han visto en las estructuras propias pero cuando observamos el entorno bajo su significación precedente $§ 1$ pág. 25, encontramos unas categorías presentes 
en cuanto a la función política misma. No hablaríamos aquí tanto de complejidad y lo que ella representa $\$ 1$ pág. 30 sino más bien de causalidades.

Y dentro de esas particularidades especiales, el sub-sistema político colombiano tiene desde sus inicios conceptos que guardan íntima relación con los objetos materiales y la obtención de beneficios particulares. Por lo menos de eso cuenta Hesper Eduardo Perez (1989), en su obra proceso del bipartidismo colombiano y frente nacional, al igual que el trabajo editado por Jose Fernando Ocampo T. (2008) de Historia de las ideas políticas en Colombia en cuya participación notables investigadores realizaron un rastreo histórico de esas muestras de dominio y constante lucha por el poder.

Finalmente, Mario Aguilera Peña y Renan Vega Cantor (1998) nos mostraron ese estudio sobre ideal democrático y revuelta popular a cuya influencia notoria se explica en algunas páginas el proceso caudillista sucedido en 1948 con las repercusiones de una izquierda como movimiento, pero que MAURICIO ARCHILA N, (2009) y otros investigadores del Centro de Investigación y Educación Popular -Cinep- elaboraron la obra Historia inconclusa izquierdas políticas y sociales en Colombia como muestra de un desarrollo de ideas o movimientos que a la postre y a partir de nuestros propósitos los podemos definir como elementos del propio sub-sistema político.

Preferimos hacer relación al inicio de las anteriores obras porque de ellas tomaremos como referencia algunos aportes a nuestra descripción política del 
pasado y que nos ayudarán a contemplar un poco del momento presente en que nos encontramos hasta el momento actual. Intentaremos entonces agrupar elementos característicos observados en la propia trayectoria política para así intentar encontrar después aspectos generales si es que los hay, y así llegar a determinar si podemos hablar de un mismo fin que encierra el subsistema de la política colombiana.

Remontando a la época de la colonización, los colonos españoles nos habían dejado formas de gobierno que para la época hoy no pretendemos atacar y mucho menos esclarecer dado el contexto en que se vivía en aquel entonces. Pero lo verdaderamente relevante lo encontramos en dos aspectos y será ésta la primera caracterización en donde la administración territorial se realizaba a partir de cabildos donde al parecer había principios de democracia. En ellos el alcalde como autoridad administrativa ejercía según lo aprobado por el cabildo.

Sin embargo, quienes tenían la posibilidad de llegar a estos órdenes tenían unas características que los separaban del resto de la comunidad colonizada: tenían una riqueza agrícola, guardaban algún prestigio social, una referencia ideológica influenciada, ellos mismos al ser los más notables establecían los procedimientos, se hacían reuniones secretas y como todavía no estaba tan presente el auge político como profesión, las personas distinguidas se dedicaban a sus negocios particulares cuando no eran épocas de juntas o decisiones. 
Las anteriores situaciones cambiaron después de la gesta de independencia donde las ideologías marcaron posición y oposición pero que con el pasar de los días se agruparon a partir de dos colores y cuyos contrastes marcaban la separación de una sociedad campesina. Fue allí donde se empezaron a notar los primeros intentos de ambición al poder y empezaron a ver cómo estar dentro de la estructura del Estado traía beneficios particulares.

Los elementos que caracterizarían a este segundo grupo sería: la violencia partidista, el bipartidismo, las primeras coaliciones, la demarcada diferencia entre el centro del país y la periferia en áreas rurales y centros urbanos, se empezó a clasificar la sociedad de aquel entonces en campesinos, burgueses y empresarios, de la misma violencia iniciada quedaron como es de esperarse los vencidos a cuyo efecto se empezó a hablar hegemonía liberal o conservadora, un retraso en el país debido a la misma batalla bélica que aunque primitiva evito el desarrollo de carreteras y del propio país, el surgimiento de los primeros movimientos protestas y marchas muchas de ellas iniciadas por los vencidos para intentar cambiar el orden político.

El tercer grupo de elementos que podemos agrupar se encuentra como una respuesta a dicha hegemonía bipartidista donde el poder público se repartía entre los integrantes de los partidos liberal y conservador pero a cuya estrategia para no "matarse entre ellos" coincidieron ambos grupos políticos una vez superado un gobierno militar, en repartirse la organización estatal. Sin 
embargo en el mundo occidental se tejían movimientos caudillistas y Colombia no estaría ajena a dicha influencia.

El cuarto grupo se entiende después de los hechos de violencia del año 1948 y que generó movimientos políticos mezclados de ideologías como rechazo a esa tradición entre liberales y conservadores. Podemos entonces hablar de algunos grupos políticos como: Frente Nacional ${ }^{13}$, Movimiento Revolucionario Liberal -MRL-14, Alianza Nacional Popular -ANAPO-15, Movimiento Obrero Independiente Revolucionario -MOIR-16, entre otros. El factor de cambio en las estructuras en el sub-sistema político consistió en que por un lado, la hegemonía continuaba haciendo presencia de los partidos tradicionales como el liberal y el conservador aunque se disfrazara en otros movimientos, el otro, consistió en una guerra firme contra las ideologías comunistas y de izquierda.

Con la desintegración de estos movimientos políticos los partidos tradicionales se robustecieron y las nuevas tendencias se atomizaron en otros movimientos pero bajo la otra impresión de sus ideologías especialmente las de izquierda, esto es, con el pensamiento de cambiar los problemas con la revolución. Ello produjo especialmente la desintegración de la ANAPO y el surgimiento en concreto de guerrillas tales como las Fuerzas Armadas Revolucionarias,

\footnotetext{
${ }^{13}$ Fecha de creación 1957

${ }^{14}$ Fecha de creación 1959

${ }^{15}$ Fecha de creación 1961

${ }^{16}$ Fecha de creación 1965
} 
Ejército del pueblo -FARC EP- el Ejército de Liberación Nacional -ELN- y el Movimiento 19 de Abril -M19-

Aunque fue el inicio de la expansión de los movimientos guerrilleros, no se encontró fecha cierta para registrar los orígenes de éstos grupos, existe sin embargo una característica tratada por los especialistas en este tipo de recopilación documental y es que su ideología de “(...) revolución se generaría desde el campo hacia la ciudad" (FERNAN GonZÁLEZ, 2008). De igual manera, dichos grupos nacen "en áreas de colonización campesina, ligados a grupos no insertos plenamente en la política del país" (p.336).

Quizá aquí entendemos ajustada nuestra explicación teórica del sub-sistema de la política §1, pág. 48, cuando hacíamos referencia que era difícil encontrar la unidad política, así como también que el Estado haya realizado sus objetivos propuestos como los de coalición y desarrollo del interés general, incluso, más allá de lo que se pretenda pensar, el concepto de soberanía se encontraba para esa época fraccionada, asunto que no es de nuestro interés ahondar pero que sí nos permite entender que al nivel del sistema social, la parte rural se encontraba con unas necesidades ignoradas casi desde los inicios de la hegemonía bipartidista a cuya expectativa los más necesitados permanecían en el olvido y otros optaron por los caminos del conflicto bélico.

Dentro de las ideologías que pudieran tener cada grupo etiquetado de izquierda, de manera breve explicaremos cómo se encontraban idealizados 
los propósitos del grupo guerrillero del M19, el cual por más que su postura fuera contra el Estado Patricia Madariaga Villegas (2009) en su escrito movimiento 19 de abril: elementos para una caracterización, escribe la que fue en su momento la propuesta del M19 que se publicó "en el diario El Bogotano el 23 de abril de 1984, incluía ${ }^{17}$ :

1. Democratización de la política interior, expresada en mayores niveles de participación popular y libertad de expresión

2. Democratización de la economía, mediante medidas como las siguientes:

- Nacionalización de la banca

- Fomento a la industria nacional

- Democratización del crédito

- Reactivación del sector agropecuario

- Reforma urbana y protección al arrendatario

- Reforma tributaria y control a la evasión de impuestos

- Renegociación de los contratos de explotación del carbón

3. Democracia social y una serie de medidas de urgencia:

- Distribución gratuita de leche para niños menores de siete años y mujeres embarazadas

- Plan de vivienda popular sin cuota inicial

${ }^{17}$ Se trascribe lo siguiente de manera textual para completar más adelante el estudio del caso particular que nos proponemos analizar. 
- Mejoramiento y subsidio de los servicios públicos

- Alza de salarios proporcional al incremento del costo de vida

- Educación primaria gratuita y obligatoria

- Respeto a los resguardos indígenas y a la cultura de sus comunidades

- Integración de las zonas de colonización a la economía nacional

4. Democracia política, que incluyera:

- Estatuto de derechos y garantías de la oposición

- Elección popular de alcaldes y gobernadores

- Reforma electoral

5. Democratización de la política exterior, expresada en:

- Apoyo al principio de autodeterminación de los pueblos

- Retiro de las tropas del Sinaí

- Rompimiento de relaciones con el régimen racista de Sudáfrica" $\ldots($ p.257)

Bajo esos postulados y de acuerdo a las dinámicas sociales de esa época, el gobierno conservador que tenía el poder ejecutivo bajo su control no sólo logro una amnistía al M19 sino que se introdujeron varias de las propuestas del grupo subversivo al sistema jurídico de aquel entonces. Lo notorio de dicho proceso fue que los anteriores elementos hicieron un cambio autorreferencial en los sub-sistemas político y del derecho colombiano permitiendo hacia inicios de 1991 una reforma político constitucional. 
De lo sucedido se entendió cómo personas marginadas - por lo menos las partes directivas del M19 emprendieron una vida política obteniendo así acceso a los puestos gubernamentales pero sin que esto haya cambiado 0 suplido las necesidades sociales a plenitud o por lo menos a quienes representaban, esto es, campesinos, marginados y sujetos no involucrados en la vida política. Con todo, podemos ahora encontrar un nuevo grupo con el inicio de la nueva constitución.

Encontramos como era de esperarse, para el año 1992, la presencia de los partidos liberal y conservador pero con inclusión de movimientos pequeños y la participación de minorías con reconocimiento jurídico frente a las maquinarias políticas dominantes. Pero las cosas, aunque tuvieron un avance en lo jurídico, lo político ahora tenía dentro de sus estructuras oposiciones pero camufladas de coaliciones para vivir de la política pero en lo referente a la sociedad, las necesidades mutaban o se hacían más agudas al punto de que éstas siguen siendo la bandera para las campañas políticas en donde como se examinó §1, pág. 61 sigue el sub-sistema político determinando lo que es considerado necesidad y la soberanía popular o unidad se encuentra dispersa.

Aunque se hubiera dado cabida a nuevos movimientos ideológicos con pocos adeptos, la hegemonía continuaba hasta el año 2006 cuando el orden de los partidos políticos tradicionales cambió con el esquema de reelección presidencial. Allí no sólo entraría en juego la burocracia necesaria para 
aprobar ese cambio constitucional sino además la formación de nuevos movimientos como el Partido Social de la Unidad Nacional -Partido de la U-18. Dicho movimiento aunque se hace llamar "partido" fue creado con la unión de diversos políticos que militaban en sus partidos originarios con el propósito de crear un cambio constitucional.

De ahí podemos observar la presencia de las reglas del sub-sistema político y ese desprecio hacia el ciudadano-elector, comoquiera que y recordando a BоввıO (2013) §1, pág. 55, se trabajaron muchas cosas políticas en secreto contradiciendo con ello lo pública que se espera sea la democracia. Así las cosas liberales y conservadores con uno que otro movimiento de minorías estaba dentro del gobierno mientras que la oposición guardaba sus escaños ganados en elecciones populares y se dedicaron a sus funciones propias menos a la de cumplir con las promesas que habrían dado a la sociedad.

Los grupos de izquierda en todo esto tenían hasta la fecha una característica en común y era la atomización de sus integrantes al encontrar contrariedades entre sus mismos miembros. De ahí podemos evidenciar como del partido Polo Democrático Alternativo -PDA- uno de sus miembros, el señor Gustavo Petro quien militó en los movimientos de izquierda desde el M19 hasta ser candidato presidencial por el propio PDA para las elecciones de 2010, salió de las filas de su partido y formó su propio grupo denominado Movimiento Progresista ${ }^{19}$.

\footnotetext{
${ }^{18}$ Fecha de creación 2005
}

${ }^{19}$ Fecha de creación 2011 
Bajo la creación de su propia ideología para configurar la existencia de su movimiento, su máximo dirigente Gustavo Francisco Petro Urrego para el periodo de gobierno 2012-2015 gano las elecciones de alcaldes y tomo posesión como burgomaestre de la ciudad de Bogotá D.C. Así transcurriría su mandato bajo figuras constitucionales de voto programático y sus consecuencias ante el eventual incumplimiento de su programa de gobierno, cuestiones que abordaremos más adelante §2, pág.162.

No obstante, la trayectoria política no se detiene. Siendo presidente Juan Manuel Santos Calderón para el periodo presidencial 2010- 2014, el máximo dirigente del país decidió entablar conversaciones con uno de los dos grupos guerrilleros aun existentes, las FARC-EP, cuyo objetivo principal se centraría en acordar la paz dentro del territorio colombiano. Teniendo en cuenta que, en su primer cuatrienio no alcanzó a concretar su cometido, buscó la reelección presidencial; sin embargo, se había forjado un nuevo grupo de oposición denominado Centro Democrático ${ }^{20}$.

La nueva oposición contaba con el expresidente Álvaro Uribe Vélez quien tenía un gran número de simpatizantes, opciones que le darían al candidato presidencial por ese partido una posibilidad de ganar las presidenciales para el periodo 2014-2018 y tal como ha sucedido desde la época de la

\footnotetext{
${ }^{20}$ Fundado en 2013
} 
independencia, se empezaron a fraguar coaliciones. Los partidos tradicionales al no tener un exponente que realzara sus ideales desde los últimos 12 años se han venido opacando sin que ello quiera decir que dejaron de existir.

Los propósitos de poder hicieron que entre los dos nuevos partidos con mayores adeptos -partido de la $\mathrm{U}$ - y -centro democrático se empezaran a pactar reglas, coaliciones, y compromisos entre distintos miembros de otros partidos para llegar a definir las elecciones presidenciales. Como una de las propuestas del Presidente Santos era llegar a un acuerdo de paz con la guerrilla de las FARC-EP, busco el apoyo de los movimientos de izquierda quienes lo respaldaron públicamente. Es de anotar que el Movimiento Progresista quien actualmente tenía el poder político de la capital del país también se uniría pero con otros propósitos como los de evitar que el gobierno nacional los dejara gobernar sin tantos obstáculos ni críticas.

Hasta aquí podemos concluir a nivel del sub-sistema político que se cumplen algunas de las explicaciones teóricas dadas anteriormente $\S 1$, p. 48. Empezaremos por decir en lo referente a las estructuras y las propias nociones de la teoría de los sistemas existen elementos notorios bajo los cuales la política se mueve, tales como pactos interpartidistas, coaliciones, secretos, intereses de unos pocos, las ganas de tener acceso al poder público, la facilidad como se crean discursos, lo débil de la oposición y la manera en que el mismo sub-sistema de derecho es manipulado desde la política para legitimar sus acciones. 
En el mismo sentido la sociedad genera en todo su recorrido una serie de necesidades sin que sean atendidas pero quizá por su mala organización para exigirlas, se alejan más de la política dejando la facultad de decisión en unos pocos. Y el Derecho, como sub-sistema ambivalente genera expectativas para los ciudadanos §1. p. 38, como también consagra reglas de obediencia. Y es esto lo que a continuación entraremos a estudiar en el entendido de la parte normativa de la democracia consagrada en la Constitución de 1991 como también en los pronunciamientos de la Corte Constitucional

\subsection{Generalidades de la democracia dentro de la Constitución DE 1991}

Aquí entramos a exponer toda esa parte normativa constitucional alusiva al sub-sistema del derecho colombiano que hace alusión a la democracia dentro de la Constitución de 1991; ahora bien, evitaremos remontarnos desde la exposición de motivos de cada artículo, puesto que ya han pasado más de 20 años de diversos pronunciamientos de la Corte Constitucional mediante los cuales han argumentado, defendido o aumentado el rango de aplicación de algunos enunciados normativos, incluso se observa cómo se va actualizando la misma Carta Política a las transformaciones globales en cuanto a la protección de derechos fundamentales se refiere. 
Así pues, las demarcaciones conceptuales sobre las cuales expondremos algunos sustentos constitucionales que tiene la democracia nos ubican en el Preámbulo y los artículos $1^{\circ}, 2^{\circ}, 3^{\circ}, 4^{\circ}, 6^{\circ}, 13,26,40$ (numeral 4ํ), $85,86,87$, 92, 103, 259 y 260 de la Constitución. Por supuesto que no explicaremos lo que cada artículo trata trascribiéndolo, más bien intentaremos explicar cómo a partir de esos enunciados existe una "estructura democrática" dentro del Estado social de derecho.

En este sentido, iniciaremos con el Preámbulo y el artículo $3^{\circ}$. Empezando, podemos sostener la existencia de la relación que guardan dichos enunciados normativos en lo que tiene que ver con ese discurso, cuya voluntad de verdad se ha impuesto al exponer que en "el pueblo" reside la soberanía popular, y que es a partir de ahí donde se justifican las leyes y todo el andamiaje del Estado, el cual debe apuntar a servir a la comunidad en aras del bienestar general. Quizá ello se predique en razón de la misma trayectoria histórica donde la "mayoría popular", desde los albores de la democracia, ha ejercido una fuerte influencia en la forma de elegir gobernantes o de derrocarlos porque atentaban contra sus derechos subjetivos.

Ahora bien, en lo concerniente al artículo 1ํ, podría darnos la impresión que la forma del Estado colombiano se determina asimismo como democrática. Dicha afirmación muestra que la democracia, aparte de ser el ejercicio a través del cual la soberanía popular se trasfiere mediante el sufragio para que de manera representativa un dirigente gobierne en nombre y representación de un Estado 
o territorio, entenderíamos además que dicho principio democrático encierra ideales dentro de cada institución del Estado en donde la mayoría de decisiones, las cuales tienen que ver con la afectación o satisfacción en lo que a derechos se refiere, tanto de una mayoría o de una persona particular, se resuelvan no tanto a partir del tan nombrado interés general, sino que esa decisión para llegar a ser lo menos arbitraria posible se realiza a partir de cuerpos colegiados y no en cabeza de una sola persona.

No obstante, ello no quiere decir que los órganos de decisión, donde solo un sujeto investido de autoridad decide sea arbitrario, puesto que para tales efectos existen en el sistema jurídico los recursos o instancias para que sea el superior jerárquico el que resuelva dicha insatisfacción, pero se esperaría que en las últimas instancias estuviera presente aquel principio democrático en donde las decisiones en todos los órdenes -judicial, legislativo, administrativode toda segunda instancia, fueran colegiaturas para verdaderamente honrar el mismo significado de vivir en democracia a parte de ejercer control y delimitación en cuanto a garantías o derechos se refiere.

Continuando con el artículo $2^{\circ}$, el cual expone los "fines del Estado", recordamos la Sentencia T-406 de 1992 (M.P.: Ciro Angarita Barón), de la cual nos valimos para explicar cómo un Estado proyecta sus valores, pero en esta orientación nos llamó mucho la atención encontrar que éstos, aunque estén escritos en un lenguaje muy abstracto en la Constitución, el legislador los desarrolla mediante leyes. Aquí entonces entenderíamos que los valores 
vienen siendo el fundamento para motivar las leyes en un país, y bajo la anterior lógica, si cada ley se crea con el propósito de servir a la comunidad, esto es, atiende las necesidades específicas de la sociedad, la pregunta es cuántas leyes ponen fin por completo a las necesidades del pasado.

En lo que tiene que ver con el artículo 4º entenderíamos, para efectos de la presente descripción normativa constitucional, que la Constitución se concibe como la máxima categoría jurídico-política dentro de la sociedad, la cual establece un orden desde el punto de vista de entender la democracia, en donde no solo las instituciones desarrollan la instrucción democrática, sino que se espera la implementación de modelos democráticos a la esfera privada, incluso en la formación dentro de las instituciones educativas, que nos hace resaltar tanto el político como el sistema jurídico deben obedecer a ciertos principios democráticos, al igual que la misma sociedad puede exigir procedimientos democráticos en lo que ellos consideren necesario, todo a partir de la misma descripción que encierra el presente artículo.

Los artículos $6^{\circ}, 26,41$ y 13 guardan una relación entre sí muy peculiar. Si intentamos conjugarlos sobre el mismo tema de la democracia, en el $6^{\circ}$ encontramos esa cláusula de responsabilidad que argumenta que los servidores públicos y los particulares son responsables por infringir directamente la Constitución y la ley, pero al referirnos a los primeros, bajo la óptica de la democracia y quién detenta la facultad de gobernar o representar, este artículo sería la primera fuente sobre la cual todo político investido de 
autoridad, y cuyo cargo se realizó mediante el sufragio, debería responder por su acción u omisión en el eventual caso que las promesas de las que se valió para pertenecer al cargo no se cumplieran.

Dicho de otro modo, si durante el pleno ejercicio democrático los políticos se hacen merecedores de una investidura bajo la cual su poder los convierte no solo en representantes de sus votantes, sino de un gobierno, qué razones eximentes de responsabilidad existirían en el eventual caso en que a sus votantes alguna decisión del gobierno o de alguna ley los afectara en vez de atender sus necesidades, y dónde ese mandato se quebranta y dejan de ser representantes de sus potenciales electores para pasar a ser unos simples observadores. Al parecer por una u otra razón el mencionado artículo 6ํ de la Constitución se emplea desde el punto de vista de la responsabilidad en el ámbito de lo contencioso administrativo, y no desde el plano político.

En lo correspondiente al incumplimiento de esa responsabilidad por parte de los particulares cuando trasgreden la Constitución o la ley, cabe preguntarnos qué tanto se fortalecen las prácticas democráticas en el ámbito privado, esto es, en la casa, la empresa, el trabajo, la industria, el sindicato, las corporaciones, el futbol, etc. De todo lo anterior, podemos concentrarnos en fenómenos repetitivos como las elecciones de representantes estudiantiles en colegios y universidades, donde algunos elegidos comparten la mesa de decisiones junto con docentes y directivos, pero la pregunta que nuevamente circula por el mismo tema no es tanto la responsabilidad del elegido, puesto 
no se puede esperar grandes obras, sino de la estructura misma que hace de esos primeros ejercicios democráticos una completa pérdida de tiempo y desinterés en que alguien se muestre atento por abogar en nombre de sus representantes, así como de los neófitos electores que ya desde sus primeras experiencias entienden que de la democracia nada interesante se puede hacer. Entonces, la estructura democrática de que hablan los artículos 26 y 41 no funciona en la mayoría de los casos.

Ahora bien, frente al tema de la igualdad de que trata el artículo 13, vemos una serie de controversias lógicas al explicarlas. Primero porque es cierto que no existe una igualdad mediante la cual todos podamos ser medidos por la misma regla, y segundo porque el mismo sub-sistema del derecho generó una categoría para demostrar que no somos tan del todo iguales.

Nos referimos aquí a la igualdad material, cuya frase se escucha (igualdad entre iguales), lo que en casos específicos termina generando tanto desprecio hacia el no igual que, terminan marginándolo o creando patologías de desprecio hacia el sujeto diferente. Todas estas consecuencias se pueden traspasar al ámbito de la democracia que se origina con el sistema jurídico mismo, pero que en lo político el objeto de la igualdad no es una norma que se pueda predicar, básicamente porque el que critica es opositor, o simplemente al no hacer parte de los órganos de poder pretende entorpecer todos los procesos y en este sentido deja de ser tratado como igual. Con tal consideración terminaremos por deducir que dicho esquema se vuelve cíclico 
donde la igualdad se ve reducida en lo político en términos de opositores y coalición. No obstante, ¿dónde queda la sociedad, o mejor, el potencial elector?

Con el anterior intento de criticar las generalidades de la democracia dentro de la Constitución de 1991 llegamos al artículo 40, específicamente el numeral $2^{\circ}$, el cual no se refiere tanto al Estado y su enfoque de "servir" a la sociedad, tampoco del político y su "responsabilidad" ante acciones u omisiones. En contraposición a lo anterior aquí hacemos referencia a que "todo ciudadano" puede "revocar el mandato de los elegidos en los casos y en la forma que establecen la Constitución y la ley".

Como se ve, esta concepción descansaría en esa premisa envolvente de los primeros artículos porque sería ahí donde el ciudadano puede volver a retomar ese poder donde descansa la soberanía de un Estado, pero el objeto de la Asamblea Nacional Constituyente no podía haber sido tan generoso, comoquiera que no lo dejó tan amplio como se esperaba en relación a todos los elegidos mediante elección popular, toda vez que ello sí hubiera sido una completa revolución de la democracia misma porque no cualquier político se arriesgaría ante un verdadero poder tan inmediato como es el de reintegrar al ciudadano su poder soberano.

Con este intento se impulsó entonces la figura de la revocatoria únicamente para Alcaldes y Gobernadores, pero tan pronto como dicho poder fue 
enunciado por el Constituyente rápidamente fue necesario reglamentarlo para evitar caer en amplitudes conceptuales que pusieran en desventaja al subsistema de la política, pero alejados de esto, indudablemente nos referimos a un derecho político que tiene la propia Constitución y elevado a la calidad de derecho fundamental según la misma descripción de la Carta cuando enmarca en el artículo 85 que incluso esos derechos políticos "son de aplicación inmediata", entendiéndose que se puede buscar su amparo acudiendo ante los jueces de tutela para la protección de sus derechos políticos fundamentales, según el artículo 86.

Así entendido el imperativo constitucional del artículo 40 numeral 4º̣, no puede ser nunca una realidad perteneciente a la órbita de la mayoría de ciudadanos insatisfechos, así sea frente a Gobernadores y Alcaldes. El significado lógico de dicho precepto apunta a una evolución de los mecanismos de participación ciudadana cuya reglamentación se realizó posterior, dando así campo para que el mismo político se valiera de esto para proteger sus propios intereses.

En apoyo provisional a la democracia, encontramos en el artículo 87 que cualquier persona ${ }^{21}$ que sienta una insatisfacción porque alguna ley o acto administrativo no se ha cumplido, puede acudir ante jueces para que dicha expectativa se haga realidad. Desde luego que no cabrían las promesas de

${ }^{21}$ Y no cualquier ciudadano puesto que no se habla de derechos políticos como los del voto, sino con una proyección aún más amplia y garantista que pueda promover (bajo nuestro entendido) una respuesta a las necesidades de cualquier sujeto que piense que una ley le soluciona una necesidad. 
políticos, pero yendo al propio sistema jurídico se puede requerir el cumplimiento de cada manifestación del poder legislativo o su materialización al poder ejecutivo, bajo el entendido que cada ley obedece a los valores de "servir a la comunidad" del artículo $2^{\circ}$ de la Constitución; incluso, como ya lo mencionamos, si cada ley intenta solucionar una necesidad y no la satisface, serían los jueces los encargados de ordenar dicho cumplimiento 22.

Ciertamente, se puede alegar en defensa del funcionario que dichos cometidos no fueron cumplidos por falta de presupuesto, deficiencia en la organización de las decisiones o incluso la culpa de anteriores gobiernos. Sin embargo, en ello radica la seriedad con que no sólo se ven los funcionarios desde sus cargos a los cuales con tanto esfuerzo aspiran en cada periodo electoral, sino la institucionalidad misma de la entidad o corporación de derecho público, puesto que no tendría presentación el prometer algo, no realizarlo y descargar su responsabilidad en eximentes o en asuntos fortuitos como por ejemplo, y entre otros, eventualidades no pensadas, errores en la designación de funcionarios de confianza, o de los propios contratistas y sus interventores, $u$ otros asuntos "varios" por resolver.

22 Aquí sin querer llegamos a la primera parte de la investigación, cuando explicábamos que cuando el sub-sistema político no responde a una necesidad, son los jueces constitucionales dentro del sub-sistema del derecho los que en últimas solucionan dicha urgencia garantizando la protección de derechos fundamentales. 
Además de lo anterior, por razones análogas el artículo 92 faculta en cualquier persona la legitimidad de poder solicitar a las autoridades competentes, diferentes de las que han incurrido en la falta, las sanciones - de tipo penal o disciplinario- derivadas de su propia conducta sin importar que su actuar haya sido por acción u omisión. Así, por ejemplo, no sólo un juez puede hacerme exigible esa ley o acto que resuelva mi necesidad, sino que otra entidad puede imponer medidas ante la insatisfacción de los deberes de quien teniendo el poder de hacer algo no lo hace.

Finalmente, y ya para dar paso al siguiente tema, encontramos que en los artículos 259 y 260 se delimita ese modo "revolucionario de la democracia" cuando se indica que para la elección de Alcaldes y Gobernadores el mandato, o mejor el "contrato social" que están obligados a seguir será ese programa de gobierno el cual debió ser presentado a la Registraduría Nacional del Estado Civil al momento de inscribirse como candidato, y el artículo 260 nos recuerda que entre otras personalidades que elegimos a través del voto programático se encuentra "(...) alcaldes y gobernadores".

En este sentido, estamos ya en condiciones de señalar, o mejor de sostener que a nivel de la propia Constitución de 1991 la apertura a ideas de la democracia no sólo es obvia sino que en apariencia fácilmente exigible, que tenemos unos derechos fundamentales políticos que pueden ser objeto de tutela por parte de jueces, pero que también éstos pueden exigirle a ese funcionario investido de autoridad en lo público que ejecute o cumpla lo que 
decidió hacer mediante actuaciones jurídico-políticas, pero al igual que sucede con la mayoría de artículos de la Constitución, cuya reglamentación se fraguo con posterioridad, entraremos a revisar las leyes que reglamentan el voto programático.

\subsection{ASPECTOS GENERALES DEL VOTO PROGRAMÁtICO}

El desarrollo normativo del voto programático en Colombia se reglamentó con las Leyes 131 y 134 de 1994, así como también con la Ley 741 de 2002, pero aunque esta última modificó en algunas partes la Ley 131 mencionada, intentaremos exponerlas y cuando sea necesario analizaremos las reformas bajo el entendido de lo que el mismo legislador elaboró.

Comenzamos con la Ley 131 de 1994 en su primer artículo; allí se explica el significado de "voto programático", y aunque no fue muy diferente al originalmente planteado por el Constituyente de 1991, el primer artículo de dicha ley tiene elementos esenciales que lo definen a tono con los mismos enunciados de la democracia, presentes en toda la Constitución, bajo el entendido que "la soberanía popular" tiene tanto representatividad como participación, pero con una carga para el político que se le impone a éste como mandato de lo que prometió en la inscripción de su candidatura.

Como se ve, existe una imposición por parte del elector a ese eventual gobernante a través del mandato a seguir durante su periodo en el cargo, pero 
no de manera arbitraria; el ciudadano le exige al político cumplir determinas cosas, porque la auto-vinculación se hace en dos momentos según los artículos $3^{\circ}$ y $5^{\circ}$ de la Ley 131 de 1994; en el primer momento esas promesas son socializadas con la comunidad y toman el nombre de programa de gobierno, el cual tendrán los candidatos que inscribir ante la Registraduría Nacional del Estado Civil en sus distintas circunscripciones.

En un segundo momento a dicho trámite se le da una publicidad donde la entidad lo publica y así cada aspirante tiene la oportunidad que los ciudadanos de sus respectivos territorios puedan conocer y comparar cada propuesta. Una vez efectuados los comicios y posesionado el nuevo gobernante éste tiene que enfrentarse al Concejo municipal de su territorio para exponerle diversas modificaciones a esos parámetros presupuestales y financieros con que inicia su mandato, con el fin de poder ajustar o modificar sus propuestas.

Ello nos devuelve de modo inexorable a cuestionarnos si aquella ferviente promesa realizada previo a elecciones realmente fue estudiada por el candidato, o la realizó por llamar adeptos pero sin futuro dentro del estudio presupuestal. Ahora bien, algo parecido a lo expuesto es la situación que también se enmarca frente al gobernador y sus promesas electorales, las cuales tendrá que entrar a ajustar o exponer a las asambleas departamentales bajo los esquemas de los planes de desarrollo. 
Continuando con la explicación de la Ley 131 de mayo 9 de 1994, el artículo $2^{0}$ nos recuerda que la revocatoria del mandato es un mecanismo de participación ciudadana y un derecho político, toda vez que se remonta a los enunciados constitucionales, artículos 40 numeral 4ํy y 103. Ahora bien, aunque la ley que estamos examinando no se refirió más al tema, este es el espacio para poder explicar en qué consiste la revocatoria como tal, para lo cual nos valdremos de la Ley 134 de mayo 31 de 1994.

Justamente en esta ley se encuentran esas "definiciones" que orientan tanto a las instituciones como a los ciudadanos, de ahí que en el artículo 6ํㅗ se hable de la revocatoria como un derecho político en cabeza de los ciudadanos y mediante el cual se puede exigir una terminación de aquel mandato otorgado tanto a gobernadores como a alcaldes. Continuando, el Título VII, denominado De la revocatoria del mandato, en los artículos del 64 al 76 se reglamentan los pasos que debe seguir el ciudadano para dicho trámite. No obstante, aunque entraremos a desarrollarlos, bástenos por aclarar que los artículos 64 y 69 de la Ley 131 de 1994 fueron modificados por la Ley 741 de 2002.

Como primer requisito para que pueda iniciarse la revocatoria del mandato se necesita de un porcentaje mínimo exigido de ciudadanos insatisfechos, esto es, del $40 \%$ del censo electoral mediante el cual ese candidato llegó a su cargo de elección popular, lo que quiere decir que sólo quienes sufragaron en esos escrutinios pueden tener pretensiones de revocatoria, excluyendo así al sujeto que se abstuvo de acudir a las urnas ese día. 
Adelantado el anterior requisito de procedibilidad se puede solicitar a la Registraduría del Estado Civil correspondiente que convoque a elecciones para revocar al alcalde o gobernador según el caso. Aquí por principio de legalidad la misma Registraduría tiene que validar que ese porcentaje exigido, en efecto, sí haya asistido a las urnas el día de las votaciones.

En el artículo 65 se encuentra que el legislador amplió el espectro del mismo constituyente, comoquiera que estableció que los ciudadanos insatisfechos al momento de diligenciar el correspondiente formulario que tiene la Registraduría para tales casos debe exponer los motivos que llevan a revocar el mandato, bien sea por "insatisfacción general de la ciudadanía" o por el "incumplimiento del programa de gobierno".

A la anterior concepción se le podría objetar que contradice el propio postulado constitucional, comoquiera que se hablaba, según el artículo 259 de la Constitución, de imponer como mandato a seguir el programa de gobierno sin entrar en consideraciones de insatisfacción general, argumento reforzado al solicitar el $40 \%$ del censo electoral de los ciudadanos que acudieron ese día a las urnas, el cual a todas luces no circunscribe a toda la población dentro de un territorio, pero sí limita a quienes no ejercieron su derecho excluyendo al que se abstuvo de sufragar. Ahora, entenderíamos que no está del todo excluido según el artículo 65, porque al consagrar la posibilidad que en el momento del diligenciamiento del formulario se escriba el incumplimiento del 
mandato, también se puede argumentar a partir de una insatisfacción general de la ciudadanía, esto es, a partir de reclamos de quienes no sufragaron ese día.

La crítica que acabamos de exponer se refiere fundamentalmente no tanto a que el interés general sea opacado por unos pocos electores, sino que por lo mismo que existe dentro del sub-sistema de la política otros políticos llamados oposición, bajo el juego de lo que es la política, este sería el mejor escenario para buscar acceder al poder público de elección popular por una vía indirecta de la democracia, tal como se señaló en la primera parte de la investigación, al considerar que la gestión del mandatario de turno atenta contra el interés general de la ciudadanía.

No obstante, en el siguiente apartado examinaremos el cambio jurisprudencial de la Corte Constitucional frente al tema de quienes no sufragaron el día de la elección pero que pueden hacerlo el día de la revocatoria, por lo de aquella insatisfacción general. Dicho argumento fue desestimado en la Sentencia C180 de 1994 (M.P. Hernando Herrera Vergara), mediante la cual se realizó la revisión constitucional del proyecto de Ley Estatutaria № 92/1992 Senado 282/1993 Cámara, "Por la cual se dictan normas sobre mecanismos de participación ciudadana", pero ocho años después se replanteó la postura de la Corte en la Sentencia C-179 de 2002 (M.P.: Marco Gerardo Monroy Cabra), donde se revisó la constitucionalidad del proyecto de Ley $N^{\circ}$ 58/00 Senado y 
219/01 Cámara, "Por la cual se reforman las Leyes 131 y 134 de 1994, reglamentarias del voto programático".

En lo que sigue con la descripción normativa de los artículos 66 al 68, se surte por parte de la Registraduría las respectivas comunicaciones de notificación al funcionario que se le va revocar su mandato, y una vez cumplidos los requisitos formales el respectivo Registrador del Estado Civil tiene que, en coordinación con las entidades municipales o departamentales, convocar a votación. Ahora bien, se llega a la aprobación de la revocatoria (art. 69) si se alcanza un porcentaje del $60 \%$ del censo electoral a favor de la salida del dirigente político en esos "segundos comicios", siempre y cuando no llegue a ser inferior del $60 \%$ del total de los votos con que el mandatario llegó al poder público de elección popular, "y únicamente podrán sufragar quienes lo hayan hecho en la jornada electoral en la cual se eligió al respectivo gobernador o alcalde" (art. 69).

Si se llegaran a cumplir los anteriores presupuestos el Registrador del Estado Civil correspondiente informará ${ }^{23}$ de los resultados de remoción del cargo al Presidente de la República o al Gobernador (si la revocatoria fue dirigida contra el alcalde), quedando así ejecutoriada y en firme la revocatoria del mandato (arts. 72 y 73). Aquí formalmente la autoridad administrativa del orden

${ }^{23}$ En el mismo sentido, el artículo 107 de la Ley 134 de 1994 señala que el Registrador del Estado Civil o el Consejo Nacional Electoral son las entidades autorizadas para comunicar los resultados de votación, y en el mismo sentido notificar a las demás autoridades que tengan relación con los procedimientos referidos o tengan que ejecutoriar actos con posterioridad. 
Nacional o Departamental a la que se comunique la revocatoria del alcalde o gobernador, según sea el caso $^{24}$, tiene que nombrar un encargado de la misma simpatía política del depuesto funcionario mientras en un término no inferior a 30 días se organizan las nuevas elecciones para ese cargo de elección $\operatorname{popular}^{25}$ (art. 74).

Formalmente ese funcionario interino deberá continuar con la gobernabilidad de ese territorio y seguir con la ejecución del mandato del destituido alcalde o gobernador "en lo que fuere pertinente" (art. 75). Aquí cabe nuevamente otra crítica al sub-sistema de derecho, toda vez que si se lo concibe como neutral, ¿cómo va a encerrar el anterior artículo la expresión "en lo que fuere pertinente" si se entiende que el programa de gobierno fue socializado, inscrito y con posterioridad debatido?

Además, si el alcalde o gobernador encargado no lo considera pertinente seguir con lo prometido en un primer momento, de manera sencilla no lo ejecuta. Dicha acción causaría una negación misma a las bases de la democracia en dos direcciones: la primera porque el nuevo político en temporalidad para ejercer el cargo del revocado funcionario no tiene la

\footnotetext{
${ }^{24}$ Sobre la facultad de que el Presidente de la República o los Gobernadores tengan esa autoridad para suspender o destituir alcaldes, la misma Constitución los faculta en el artículo 314.

25 Según la Corte Constitucional, en Sentencia C-011 de 1994 (M.P.: Alejandro Martínez Caballero), el periodo constitucional del revocado cesa de manera automática, y surgidas las nuevas elecciones para la designación del nuevo alcalde o gobernador -según sea el caso concreto-, su periodo comienza a contarse a partir de la fecha en que se posesiona, disponiendo a partir de ahí de la totalidad del periodo constitucional previsto para ese cargo.
} 
legitimidad de la soberanía popular, y lo segundo radica en que de manera casi arbitraria puede designar, amparado en la misma ley, qué considera pertinente hacer o dejar de hacer.

Finalmente, en lo que tiene que ver con la regulación de la revocatoria del mandato se tiene que el artículo 70 le garantiza al alcalde o gobernador que no se podrá con posterioridad volver a intentar por la vía democrática expulsarlo de su cargo en lo que resta de su periodo, si en el proceso de las elecciones realizadas con el propósito de revocarlo no se superan los umbrales establecidos. Podrá inscribirse como candidato para las nuevas elecciones de alcalde o gobernador cualquier ciudadano que cumpla los requisitos de ley (art. 71), y si llegado el caso una vez realizada la revocatoria se altera el orden público el Presidente de la República puede aplazar las elecciones (art. 76).

Hasta aquí nos referimos a la reglamentación que sobre la revocatoria del mandato desarrolla la Ley 134 de mayo 31 de 1994. Por otra parte, continuaremos con el artículo $7^{0}$ de la Ley 131 de mayo 9 de 1994, modificada por la Ley 741 de 2002, la cual fijó como requisitos para iniciar la revocatoria haber trascurrido no menos de un año de posesionado el alcalde para que el ciudadano inconforme, al no encontrar en ejecución o ya desarrolladas algunas promesas realizadas, pueda presentar solicitud de revocatoria del mandato suscrita por el $40 \%$ de inconformes del total de votos que obtuvo el 
entonces candidato ganador debidamente motivado ${ }^{26}$ ante la Registraduría del Estado Civil correspondiente.

Aunque suene extraño, desde el parágrafo del mismo artículo $7^{\circ}$, hasta el artículo 16 dicha ley contempla lo mismo que la 134 de 1994, por esta razón no trascribiremos lo mismo sino con la aclaración nos basta para examinar la Ley 741 de 2002, art. 11 contempla:

“(...) la revocatoria del mandato para gobernadores y alcaldes, al ser ésta aprobada en el pronunciamiento popular por la mitad más uno de los votos ciudadanos que participen en la respectiva convocatoria, siempre que el número de sufragios no sea inferior al cincuenta y cinco por ciento (55\%) de la votación válida registrada el día en que se eligió al respectivo mandatario".

Con las anteriores concepciones normativas se muestra como desde 1994 se han regulado los casos de revocatorias del mandato, de los cuales hasta el momento de concluir la presente investigación ninguno ha tenido éxito, y aunque es cierto que las insatisfacciones han existido desde siempre en cuanto a los procedimientos democráticos se refiere, las anteriores explicaciones normativas tenemos que examinarlas ahora a partir de lo dicho por la jurisprudencia de la Corte Constitucional.

${ }^{26}$ En este artículo no se aprecia la apertura tan abierta como lo hace la Ley 134 de 1994, art. 65 , esto es, por "insatisfacción general de la ciudadanía". 


\section{JURISPRUDENCIA DE LA CORTE CONSTITUCIONAL SOBRE EL VOTO PROGRAMÁTICO Y LA REVOCATORIA DEL MANDATO}

En este apartado analizaremos unas sentencias de la Corte Constitucional, las cuales clasificaremos en dos grupos según el tema que nos interesa: el primero sobre el voto programático y el segundo en lo que tiene que ver con la revocatoria del mandato. Iniciamos con la Sentencia C-011 de 1994 (M.P.: Alejandro Martínez Caballero). En este primer fallo el alto tribunal constitucional examina el control jurisdiccional ${ }^{27}$ de constitucionalización de la ley estatutaria que reglamenta el voto programático.

En dicho fallo se observa cómo la Corte realizó el control formal de la ley estatutaria, esto es, la revisión de que se hayan surtido los debates correspondientes en Senado y Cámara de Representantes dentro de una misma legislatura; también analizó que cada uno de los artículos de la Ley 131 de 1994 estuvieran sistemáticamente alineados a los propios parámetros del ordenamiento constitucional. Entonces, tal y como podemos observar en dicha ley, entendemos que se encuentra ajustada a todo el compendio normativo de la Constitución de 1991.

${ }^{27}$ El cual se considera previo según el artículo 153 de la Constitución, es decir, que para que la Corte Constitucional examine una ley estatutaria no se requiere de la existencia de una demanda presentada por un ciudadano. 
En ese sentido, la sentencia exploró el desarrollo que el legislador diseñó para reglamentar el voto programático, por supuesto que los artículos o parágrafos que no encontró ajustados a la Constitución los declaró inexequibles. En otras palabras, la mayor parte de la Ley 131 de 1994, desde ese análisis de constitucionalidad, se encuentra todavía incólume, lo que quiere decir que desde el punto de vista legal-constitucional se garantiza a todos los ciudadanos el procedimiento para revocar a gobernadores y alcaldes en cuanto a su programa de gobierno se refiere, el cual es el mandato a seguir, y sobre ese mismo se le exigirán resultados.

Ahora bien, como no se trata únicamente de hablar de un enunciado constitucional (art. 259) que fije la posibilidad del voto programático y la reglamentación que se hizo del mismo en la Ley Estatutaria 131 de 1994, comprendemos que a nivel interno de organización administrativa, para que exista decisión y ejecución por parte del alcalde o gobernador, es necesario ajustar su programa de gobierno a los planes de desarrollo dentro de los municipios o departamentos, y para ello la Ley 152 de 1994, "Por la cual se establece la Ley Orgánica del Plan de Desarrollo", en el artículo 40, inciso final, consagra: “(...) Toda modificación que pretenda introducir la Asamblea o Concejo debe contar con la aceptación previa y por escrito del Gobernador o Alcalde, según sea el caso".

Dicho apartado fue objeto de demanda de acción pública de inconstitucionalidad bajo el entendido de los demandantes, se les está limitado 
las funciones a los Concejos Municipales al permitir que los alcaldes suscriban y acepten modificaciones, ya que éstos deben elaborar oportunamente los proyectos y planes de desarrollo, y según lo establecido en el artículo 71 de la Ley 136 de 1994, los alcaldes tienen que presentar el respectivo proyecto al Concejo, y éstos a partir de ahí asumen competencia plena.

Además porque, al parecer de los demandantes, los Concejos Municipales tienen mayor representatividad siendo la máxima autoridad administrativa del municipio, y por ende los acuerdos municipales cobijan a la población en general. En el mismo sentido, se limita la autonomía de los Concejos cuando estas corporaciones tendrían que "contar de manera precisa y expresa con la aceptación del alcalde para poder introducir modificaciones al proyecto de acuerdo que sobre el tema éste ponga a su consideración" (Corte Constitucional, Sentencia C-538 de 1995, M.P.: Fabio Morón Díaz).

Aunque la Corte resolvió el tema indicándoles a los demandantes sobre el yerro en que éstos incurrieron al desconocer la jerarquía y el concepto que tiene una ley orgánica frente una ley ordinaria, sobre la cual se fundamentaron para defender su postura y atacar la Ley Orgánica de Plan de Desarrollo, en la Sentencia C-538 de 1995 encontramos la conexión jurídica entre la modificación de las propuestas de gobierno para incluirlas dentro de los Planes de Desarrollo y la responsabilidad que estas vayan suscritas por el alcalde, pues a partir del voto programático la responsabilidad política apunta a los alcaldes frente a sus electores, justamente por aquello que se comprometió a 
cumplir. Por esta razón, si las propuestas de gobierno van a ser modificadas por el concejo municipal, requerirán de la firma de quien tiene un mandato por hacer.

Lo que debe entenderse más bien, precisa la Corte Constitucional, es una labor conjunta entre el concejo municipal y el alcalde, bajo una dinámica mediante la cual éste pone a consideración de la corporación municipal las propuestas presentadas que llamaron la atención de los ciudadanos y las cuales lo llevaron a ser posesionado como máxima autoridad ejecutiva, esperando entonces del propio concejo sus opiniones para eventualmente modificar o replantear algún aparte de las iniciativas de los Proyectos de Acuerdo que presente, y si es el caso aceptar algunas correcciones bajo su consentimiento y autorización, todo lo cual se hace con el propósito de evitar traumatismos al momento de elaborar el Plan de Desarrollo.

Lo anterior tiene lógica en el sentido de que fue el político quien en campaña electoral a la alcaldía pudo consolidar esas necesidades de la comunidad, y que fueron aceptadas por medio del voto para su pronta solución. De ahí que las propuestas para formular el plan de desarrollo y sus modificaciones tengan como responsable directo al alcalde, quien como se insiste es la persona que tiene en su cabeza el mandato a cumplir, "de ahí que no sea admisible que comparta esas atribuciones con otras entidades u organismos, que muy seguramente tendrían otras prioridades y manejarían otra racionalidad" (Corte Constitucional, Sentencia C-538 de 1995, M.P.: Fabio Morón Díaz). 
Ya para finalizar, la Corte extendió el anterior razonamiento también para los casos del Gobernador frente a las Asambleas Departamentales, toda vez que el mismo artículo 259 de la Constitución clasifica sus propuestas de gobierno como ese mandato a seguir, y bajo esa misma dinámica tiene que buscar exponer los proyectos de ordenanzas departamentales ante la Asamblea con las anteriores explicaciones.

Otro tema que refuerza la responsabilidad de alcaldes y gobernadores frente a esa responsabilidad política de cumplir sus promesas electorales versa sobre la facultad que tienen éstos de "nombrar" funcionarios como representantes del departamento, distrito o municipio en juntas y consejos directivos de entidades descentralizadas. Sobre el particular la Corte Constitucional, en Sentencia C-1258 de 2001 (M.P.: Jaime Córdoba Triviño) se pronunció sobre la constitucionalidad del artículo 49 de la Ley 617 de 2000.

En el entendido de la Corte, alcaldes y gobernadores pueden en relación con los agentes que ellos mismos encuentren necesarios para el desarrollo del programa de gobierno, nombrar gerentes, directores o presidentes de las aludidas entidades descentralizadas, esto es, funcionarios del sector central o descentralizado de su competencia, de libre nombramiento y remoción, en el entendido de que no se le pueda obstaculizar el mandato impuesto por la ciudadanía por ser una carga impuesta expresamente por obligaciones de hacer. Además, aunque la Constitución no tiene norma expresa que prohíba 
eventuales situaciones de nombramiento por parte de alcaldes 0 gobernadores, el legislador sí puede limitar los nombramientos que hagan éstos, pero que en el caso del artículo 49 de la Ley 617 de 2000 se declaró por parte de la Corte Constitucional exequibles los apartes demandados, pero condicionó la expresión "nombrar" a la explicación que ya dimos.

En lo que sigue examinaremos dos sentencias de la Corte Constitucional, la C-180 de 1994 (M.P.: Hernando Herrera Vergara), mediante la cual se realizó la revisión constitucional del proyecto de Ley Estatutaria № 92/1992 Senado 282/1993 Cámara, "Por la cual se dictan normas sobre mecanismos de participación ciudadana", y la C-179 de 2002 (M.P.: Marco Gerardo Monroy Cabra), donde se revisó la constitucionalidad del proyecto de Ley $\mathrm{N}^{\circ} 58 / 00$ Senado y 219/01 Cámara, "Por la cual se reforman las Leyes 131 y 134 de 1994, reglamentarias del voto programático".

La Sentencia C-180 de 1994, aunque trata de la reglamentación de los distintos mecanismos de participación ciudadana, nos centraremos en cuanto a nuestro tema de investigación corresponde, esto es, de la revocatoria de mandato, sin que dejemos de lado la noción de soberanía que trabajó la Corte Constitucional. Empezando, tenemos que con la Constitución de 1991 la Asamblea Nacional Constituyente encontró muy pertinente dejar en manos del pueblo el ejercicio de la soberanía popular plasmándolo en el Preámbulo y en los artículos $1^{\circ}$ y $2^{\circ}$. 
En dichos artículos se encuentra que la institución de la democracia se entiende desde dos ópticas: la democracia representativa y la directa. La primera genera un "mandato imperativo" (Sentencia C-180 de 1994. M.P.: Hernando Herrera Vergara) entre ciudadanos y gobernante esto quiere decir que la participación de la ciudadanía se configura necesaria en todo el ejercicio del mandato, y asimismo el gobernante tiene la responsabilidad durante todo su periodo de hacer partícipe a la ciudadanía de la mayoría de las decisiones políticas.

Lo que pareció interesante en el aporte de la referida sentencia fue esa distinción que hizo la Corte Constitucional entre mandato imperativo y mandato representativo o libre: en el primero los gobernantes se encuentran obligados por esos mandatos que los propios electores le impusieron cuando ejercieron su derecho al voto; cosa distinta encontramos en el segundo, cuando no existe ningún tipo de responsabilidad para aquel funcionario, sino que sigue sus postulados sin aprobación alguna o imposición. Al respecto señaló la Corte,

"La doctrina ha acuñado el concepto de mandato libre en virtud del cual «el representante lo es de la nación entera y no del grupo o región que lo ha elegido», concepto que sufrió cambios de especial trascendencia, hasta llegar hoy al actual mandato programático que le confieren los elegidos al elector a través del programa que éste haya presentado en las elecciones" (Sentencia C-180 de 1994. M.P.: Hernando Herrera Vergara). 
Pero como dicha renovación institucional de la democracia no aplicaba a todos los mandatarios elegidos por elección popular, el constituyente optó por enmarcarlo únicamente para alcaldes y gobernadores, según lo reflejó en el artículo 259 de la Constitución, en donde ninguna decisión que tome el respectivo mandatario puede ser ajena al elector, toda vez que desde el mismo programa de gobierno el entonces candidato lo presentó y socializó ante la comunidad, éstos ya tienen en principio una ficción política de lo que se hará una vez se encuentre posesionado el gobernante, "de ahí que quienes tienen derecho, jurídica y políticamente a revocar un mandato, sean las mismas personas que lo confirieron u otorgaron. No quienes son ajenos a la relación establecida, que en este caso es la de elector-elegido" (Sentencia C-180 de 1994. M.P.: Hernando Herrera Vergara).

Así las cosas, la revocatoria del mandato parte de una relación directa entre mandatario y mandante, excluyendo a quienes no hayan sufragado ese día, tratándose de un juicio de responsabilidad política directa, más no de carácter judicial donde pueden acudir terceros afectados, o de un proceso de pérdida de investidura, como quiera que para tales efectos ya existe jurisdicción competente para ello. Entonces puede iniciar el proceso de la revocatoria todo aquel que participó del proceso democrático, esto es, aquellos que el día de elecciones asistieron a las urnas a ejercer su derecho al voto y con ello manifestarán su soberanía en designar a quien tendrá el poder por un periodo determinado. 
Otro de los puntos que la Corte recordó es que la revocatoria sólo puede iniciarse una vez haya trascurrido un año el gobernante en el ejercicio de su cargo, y únicamente pueden revocar el mandato los ciudadanos que participaron, "lo cual es constitucional, teniendo en cuenta la naturaleza de la institución del mandato, en virtud de la cual, sólo quien confiere un mandato es quien está facultado para revocarlo, pues «quien nada otorga, nada puede revocar»" (Sentencia C-180 de 1994. M.P.: Hernando Herrera Vergara), pero ello no quiere decir que una vez revocado el mandato los que no ejercieron su derecho al voto no tengan oportunidad para elegir nuevo mandatario.

Así las cosas, una vez terminado el examen de constitucionalidad, mediante el cual se realizó la revisión constitucional del proyecto de ley estatutaria $\mathrm{N}^{\circ}$ 92/1992 Senado - 282/1993 Cámara, "Por la cual se dictan normas sobre mecanismos de participación ciudadana", dejó como texto definitivo para la sanción presidencial la parte pertinente de la revocatoria del mandato y la que examinamos, así28:

“(...) Artículo $6^{\circ}$. Revocatoria del mandato. La revocatoria del mandato es un derecho político por medio del cual los ciudadanos dan por terminado el mandato que le han conferido a un gobernador o a un alcalde". (...).

\section{"TíTULO VII}

\section{"DE LA REVOCATORIA DEL MANDATO}

\footnotetext{
${ }^{28}$ Se copió textualmente. Las subrayas son fuera de texto, pero las indicamos de manera ilustrativa para que el lector se oriente acerca de lo que fue el análisis para la Corte Constitucional en la sentencia.
} 
"Artículo 63. Revocatoria del mandato. Previo el cumplimiento de los requisitos exigidos por esta ley para la presentación e inscripción de iniciativas legislativas y normativas, un número de ciudadanos no inferior al $40 \%$ del total de votos válidos emitidos en la elección del respectivo mandatario, podrá solicitar ante la Registraduría del Estado Civil correspondiente, la convocatoria a la votación para la revocatoria del mandato de un gobernador o un alcalde. Sólo podrán solicitar la revocatoria quienes participaron en la votación en la cual se eligió al funcionario correspondiente".

“Artículo 64. Motivación de la revocatoria. El formulario de solicitud de convocatoria a la votación para la revocatoria, deberá contener las razones que la fundamentan, por la insatisfacción general de la ciudadanía o por el incumplimiento del programa de Gobierno".

“Artículo 68. Aprobación de la revocatoria. Se considerará revocado el mandato para gobernadores y alcaldes, al ser ésta aprobada en la votación respectiva por un número de votos no inferior al sesenta por ciento $(60 \%)$ de los ciudadanos que participen en la respectiva votación, siempre que el número de sufragios no sea inferior al sesenta por ciento $(60 \%)$ de la votación registrada el día en que se eligió al mandatario, y únicamente podrán sufragar quienes lo hayan hecho en la jornada electoral en la cual se eligió al respectivo gobernador o alcalde". 
Con lo anterior las Leyes 131 y 134 de 1994, a juicio de la Corporación Constitucional, con las Sentencias C-011 de 1994 (M.P.: Alejandro Martínez Caballero), mediante la cual se realizó revisión de constitucionalidad del Proyecto de Ley Estatutaria "Por el cual se reglamenta el voto programático y se dictan otras disposiciones", y la C-180 de 1994 (M.P.: Hernando Herrera Vergara), en donde se revisó el Proyecto de Ley Estatutaria № 92/1992 Senado - 282/1993 Cámara, "Por la cual se dictan normas sobre mecanismos de participación ciudadana", quedaron incólumes hasta que, ocho años después por iniciativa del Honorable Senado de la República, decidieron realizar unos cambios nuevamente a la revocatoria del mandato, que entre los varios argumentos encontrados en la exposición de motivos, podemos unificarlos en el siguiente:

"De cerca de 80 intentos de revocatoria, sólo cinco han llegado a la etapa de pronunciamiento popular, y ninguno ha prosperado. Esto sugiere y así lo han sostenido varios analistas y políticos experimentados, que las exigencias de la ley no son realistas" (Corte Constitucional, Sentencia C-179 de 2002, M.P.: Marco Gerardo Monroy Cabra).

Fue así como se presentó el Proyecto de Ley 58/00 Senado - 219/01 Cámara para reformar las Leyes 131 y 134 de 1994, reglamentarias del voto programático. Como era de esperarse, todo el proyecto fue remitido a la Corte Constitucional para que realizara el control jurisdiccional, en el entendido de revisar si alguna de las normas creadas por el órgano legislativo estaba 
conforme a la Constitución o no. El pronunciamiento por parte de la Corte se realizó en la Sentencia C-179 de 2002 (M.P. Marco Gerardo Monroy Cabra).

Sobre el particular encontramos modificado el porcentaje para que fuera viable la revocatoria, lo observado dentro de toda la sentencia fue un escenario propicio a partir de las intervenciones del Ministerio Público hasta la ponencia misma, entraran a modificar la jurisprudencia que la propia Corporación tenía frente a quienes podían votar por la revocatoria del mandatario. Así las cosas, y alejados de la revisión formal que sobre el particular realizó la Corte, entramos a examinar las consideraciones frente a la modificación realizada por el Legislador y el campo de acción que se dio la misma Corte para "mejorar" el instituto de la revocatoria del mandato, modificando lo estipulado en la Sentencia C-180 de abril 14 de 1994 (M.P.: Hernando Herrera Vergara).

Aquí, nuevamente la Corte no perdió oportunidad para desarrollar el concepto de soberanía popular y encontrar las diferencias de ésta frente a la soberanía nacional, recordándonos que, tratándose de la soberanía popular, con ROUSSEAU (2010) aquella le pertenece al pueblo desde esa ficción de la suma de todas las voluntades generales. Más aún, al estar configurado un Estado a partir de la democracia representativa, "los funcionarios públicos elegidos democráticamente representan a la nación entera y no a sus electores individualmente considerados, por lo cual el mandato que reciben no les impone obligaciones frente a los electores" (Sentencia C-179 de 2002, M.P.: Marco Gerardo Monroy Cabra). No obstante, en los términos de una 
democracia participativa, el candidato vencedor del procedimiento democrático no sólo representa la voluntad general del pueblo, sino que además se hace a una carga de responsabilidad política adquirida por esa voluntad popular, esto es, un mandato imperativo.

Así las cosas, no todas las decisiones tomadas por el gobernante corren por su cuenta y riesgo, bajo el pretexto de hablar en representación de una soberanía popular, sino que algunas decisiones que versen sobre intereses generales pueden, llegado el caso, ser modificadas, complementadas o desestimadas por el propio pueblo, “(...) Asimismo las decisiones que adopten dichos representantes pueden ser controladas a través de la revocatoria del mandato (mecanismos de participación-decisión)" (Sentencia C-179 de 2002, M.P.: Marco Gerardo Monroy Cabra).

De acuerdo a lo anterior, la democracia representativa no es solo el medio para que un gobernante hable y se manifieste legítimamente frente a los demás; también se va a permitir una mayor participación e injerencia de la ciudadanía en las decisiones que determinen el vivir de la comunidad.

Una vez recordada la importancia de la soberanía popular, la Corte dio por entendido el orden en que las leyes reglamentan el voto programático, esto es, mediante la Ley 131 de 1994, donde se conceptualizó el contenido de lo que debía entenderse por voto programático, y en la Ley 134 de 1994, la cual desarrolló la revocatoria del mandato entendida como el derecho político que 
tiene cualquier ciudadano para dar por terminado el mandato, pero frente al tema sólo pueden revocar el mandato aquellos ciudadanos que hubieran participado en la elección popular de ese gobernante, en tal sentido la Corte se dio la oportunidad para reformar sus anteriores pronunciamientos de "las Sentencias C-011 de 1994 y C-180 del mismo año, relativa a la titularidad del derecho de revocar el mandato de los alcaldes y gobernadores" (Sentencia C179 de 2002, M.P.: Marco Gerardo Monroy Cabra).

Para llegar a justificar su nueva postura, la Corte analizó el artículo 259 de la Constitución no a partir de una lectura parcializada e independiente del mismo enunciado normativo, por el contrario, se comprendió que la revocatoria es un derecho fundamental justificado dentro de la misma Carta Política, la cual no debe ser restrictiva únicamente a quienes hayan elegido alcalde o gobernador, toda vez que desbordaría el propósito mismo de la democracia participativa. A partir de esa postura se atacaron los anteriores fallos que tenían una postura reduccionista de la democracia participativa y lo ampliaron con fundamento a partir de la misma textura abierta del artículo 40 de la Constitución, bajo el entendido de que "todos (sic) los ciudadanos tienen derecho a revocar el mandato".

Del mismo modo como el artículo 259 tiene que entenderse de una manera donde la democracia participativa pueda ser más amplia, también debe asegurarse que se cumpla lo establecido por el artículo 103 de la Constitución, pues cuando enuncia entre los distintos medios de participación democrática, 
describe asimismo la revocatoria del mandato, entonces no se puede entender que únicamente va dirigida a quienes hayan elegido alcaldes y gobernadores, sino a toda la ciudadanía enmarcada dentro de un municipio o departamento. De esta manera es que se pasa de una democracia representativa a una participativa la cual garantiza cada vez más la inclusión de todos los ciudadanos, porque además señalo la Corte, que en el ejercicio de las elecciones puede haber una serie de obstáculos que impidiera a todos sufragar, tal es el caso de las personas que no votaron porque no tenían la mayoría de edad requerida para el ejercicio democrático, pero que se sienten afectados por las decisiones políticas y en ese interregno cumplieron su mayoría de edad. Lo mismo sucede cuando por fuerza mayor no se alcanzó a ejercer el derecho al no encontrarse en otras actividades personales, pero que tienen la misma oportunidad para revocar el mandato al sentirse primero que todo miembros de un mismo territorio y eventualmente afectados en su diario vivir por las contingencias de esa administración departamental o municipal. En otras palabras, la insatisfacción general de la ciudadanía no se puede dejar de lado bajo el argumento de que el titular del derecho político fue designado por unos pocos. En este último sentido, la Corte preciso:

"Limitar el alcance del derecho a esta forma de control político acudiendo al argumento según el cual sólo los que sufragaron en la elección del mandatario le confirieron mandato, es traer al derecho público, sin fundamento alguno, la figura del mandato del derecho privado en la cual los intereses en juego son únicamente los de los contratantes -mandante y 
mandatario-. El derecho público que regula relaciones jurídicas en las cuales siempre subyace el interés general, no puede transmutar la figura sin variaciones, pues por encima de la relación estrictamente personal entre el elector y el elegido, se superponen los intereses de todos" (Sentencia C-179 de 2002, M.P. Marco Gerardo Monroy Cabra).

Así las cosas, los argumentos expuestos por la Sentencia C-180 de 1994 (M.P.: Hernando Herrera Vergara), tal como lo explicamos en líneas atrás, fueron modificados por la Sentencia C-179 de 2002 (M.P.: Marco Gerardo Monroy Cabra), bajo el entendido de que la democracia participativa fuera más incluyente a todas las personas integrando la unidad normativa de la Constitución en todo lo relacionado con la democracia y no sólo a partir de una lectura cerrada del artículo 259, pues para nuestro juicio lo que la Corte dejo de lado fue quizá el razonamiento al que llegamos en el estudio de la parte dogmática, cuando nos referimos a los intereses dentro del sub-sistema de la política que buscan tener acceso al poder muchas veces sin tener en cuenta los propósitos de los más necesitados o valiéndose de ellos para lograr sus fines particulares, o es esta quizá la mayor debilidad de la democracia cuyo paliativo no se ha descubierto o estudiado para poder evitarlo.

Ahora bien, con las nuevas exigencias que consagró la Corte entramos en el siguiente apartado a explorar cómo es que la Registraduría Nacional del Estado Civil ha manejado el tema de las revocatorias del mandato a alcaldes o gobernadores, una vez reglamentada la revocatoria del mandato. Es por ello 
que examinaremos la dinámica del Registrador frente a todo el procedimiento que se adelanta para llevar a cabo una revocatoria del mandato.

\subsection{El papel de la Registraduría Nacional del Estado Civil FRENTE A LA REVOCATORIA DEL MANDATO}

A parte de las anteriores leyes y los pronunciamientos de la Corte Constitucional, a nivel del Poder Ejecutivo se produjo el Decreto 895 de 2000, por medio del cual se reglamentó la parte operativa de la Ley 134 de 1991. En sus formulaciones se encuentran los conceptos y aspectos técnicos para la recolección de firmas y el apoyo que brinda la Registraduría a los ciudadanos interesados en promover la revocatoria del mandato.

Por otra parte, la Registraduría Nacional del Estado Civil también ha proferido una serie de actos administrativos que ayudan a evitar las contingencias del procedimiento, entre otras, la reglamentación proferida por la Registraduría Nacional del Estado Civil que regula el protocolo para la verificación de las firmas descritas en las Resoluciones 1056 de marzo 25 de 2004, y 023 de enero 5 de 2005. También en la Circular 052 de 2005 se exponen algunos aspectos relacionados con el procedimiento de revisión de apoyo que los promotores radican para intentar una revocatoria, y por último encontramos la Circular 174 de 2012. 
Ahora bien, en lo que tiene que ver con el interrogante de si la solicitud presentada ante la Registraduría Nacional del Estado Civil es susceptible de los recursos en sede administrativa contemplados en el artículo 74 y siguientes del Código de Procedimiento Administrativo y de lo Contencioso Administrativo, según consulta elevada por parte del señor Registrador Nacional del Estado Civil ante el Consejo Nacional Electoral, dicha Corporación sostuvo que "una vez presentada la solicitud de revocatoria se da inicio a la actuación administrativa" (Consejo Nacional Electoral. Rad. 1668 de 2009. C.P.: Ciro Muñoz Oñate).

En otras palabras, una vez radicada la solicitud de revocatoria, por parte de los ciudadanos inconformes o porque el programa de gobierno no se cumplió en parte durante el año que otorga la ley para que empiece a desarrollarse el mandato de alcaldes o gobernadores, el Registrador Nacional del Estado Civil o las Registradurías Municipal, Especial, Auxiliar, Distrital o Delegados Departamentales (según el caso), verifican que se cumplan los requisitos técnicos anteriormente descritos, y mediante acto administrativo motivado certifican ${ }^{29}$ el cumplimiento de los requisitos contemplados en las Leyes 131 y 134 de 1994, y 741 de $2002^{30}$; igual en el caso que no se ajuste a los

29 En ésta se verifica el total de firmas que se recibieron para solicitar la revocatoria, especificando si se logró el requisito formal del porcentaje requerido.

${ }^{30}$ Entre otros, un número de firmas no inferior al $40 \%$ del total de los votos que obtuvo el mandatario elegido. 
parámetros establecidos, se motivará la decisión y hasta ahí llega la solicitud de revocatoria.

Quedando en firme el acto que contenga la decisión del Registador respectivo, se notifica personalmente dentro de los 5 días siguientes o por el medio más eficaz posible ${ }^{31}$ a los promotores de la iniciativa y al funcionario sobre el cual se vaya a iniciar el trámite de revocatoria del mandato; en dicha comunicación se le debe aclarar a éste último que no se trata de infórmale de un "«hecho», sino de un acto administrativo por el cual se da por culminado el procedimiento originado en la solicitud de la convocatoria a la votación para la revocatoria, [de ahí que] (...) ha de entenderse como la notificación al interesado" (Consejo Nacional Electoral. Rad. 1315 de 2005).

Es de aclarar que lo contentivo en dicha notificación también debe señalar los recursos con que cuenta y ante quién presentarlos. Con la notificación de la certificación y resueltos los recursos, si fueron desfavorables para el alcalde o gobernador $^{32}$, se pone fin a la vía administrativa, y el Registrador cuenta a partir de ese momento con un máximo de dos meses para convocar a los ciudadanos del respectivo territorio donde se va a promover dicho proceso, es decir, votar por la revocatoria del dirigente que los tiene insatisfechos, para lo

31 En su defecto, la notificación por edicto.

32 Es de aclarar que la forma en que se pueda "atacar" dicho acto administrativo del respectivo Registrador únicamente puede objetarse a partir de errores en las formalidades que exige las Leyes 131 de 1994, 134 de 1994 y 741 de 2002, por lo que le está prohibido al Registrador cualquier razonamiento de valor, toda vez que se trata de un juicio político que hace la misma ciudadanía y no uno jurídico que resuelve un juez en derecho. 
cual es deber de la Registraduría respectiva solicitar el apoyo de las autoridades electorales del municipio o departamento para que se comunique a toda la comunidad la convocatoria para dicho evento.

En lo que tiene que ver con las actuaciones posteriores al escrutinio se deben examinar en concreto dos situaciones que contempla la Ley 741 de 2002 , artículo 1ํ, que modificó los artículos 11 de la Ley 131 de 1994 y 69 de la Ley 134 de 1994:

“(i) Que el número de sufragios registrados en la fecha en que se ha convocado a la votación no sea inferior al $55 \%$ de la votación válida registrada el día en que se eligió al respectivo mandatario y, (ii) Que la revocatoria del mandato sea aprobada en el pronunciamiento popular, por la mitad más uno de los votos de los ciudadanos que participen en la respectiva convocatoria" (Consejo Nacional Electoral. Rad. 1668 de 2009. C.P.: Ciro Muñoz Oñate).

Cumplidas esas formalidades legales el Registrador, siguiendo el procedimiento establecido, debe comunicar al Presidente o Gobernador para que procedan a remover del cargo al mandatario revocado por la ciudadanía, comoquiera que por la misma forma del procedimiento dicha revocatoria es de ejecución inmediata una vez el registrador certifique los resultados de los sufragios. Desde el momento en que la autoridad encargada depone del cargo al dirigente saliente es su deber nombrar un sustituto de manera provisional, 
del mismo partido o movimiento político del dirigente político removido, y se convocará a nuevas elecciones dentro de los 30 días siguientes una vez se tenga conocimiento del decreto presidencial o la ordenanza departamental que así lo ordene.

Como podemos observar en todo este proceso que contempla el desarrollo normativo, jurisprudencial y administrativo de la revocatoria del mandato frente al incumplimiento del programa de gobierno o la insatisfacción general de la comunidad que se ve afectada por la mala gobernabilidad de alcaldes 0 gobernadores, todo el sub-sistema del derecho interviene en su totalidad, pasando por las propias leyes y el poder legislativo, ingresando a control de juridicidad por parte de la Corte Constitucional, y volviéndolo más técnico por parte del poder ejecutivo o de la misma Registraduría Nacional del Estado Civil.

Así las cosas, pareciera que todo el andamiaje jurídico en cuanto al tema concreto se encuentra estructurado para superar cualquier tipo de adversidad por parte del sub-sistema de la política, y en concreto del político dirigente; lo que se deja de lado, aunque parezca incoherente, es la misma necesidad de la sociedad insatisfecha, toda vez que hasta donde se exploró el tema no existe institución en ningún orden -legislativo, ejecutivo, judicial- que obligue o haga cumplir dichas promesas electorales, y no se puede argumentar que a quien designen de manera provisional vaya a cumplir lo faltante por hacer 0 mejore la situación desfavorable de la comunidad. 
Del mismo modo, si hablamos de una falta de legitimidad del funcionario designado, desde el punto de vista electoral, y teniendo en cuenta la normatividad vigente analizada junto con jurisprudencias de la Corte Constitucional, es de resaltar que se deja de lado el cumplimiento de las promesas y asimismo en el eventual caso que se convoque a nuevas elecciones, salta a la vista la siguiente pregunta: ¿dónde quedan las promesas inconclusas?, o si los nuevos candidatos a ocupar el cargo del removido funcionario tienen que incluir dentro de su plan de gobierno la continuidad de lo dejado de hacer, incluso, si puede reformular el Plan de Ordenamiento que garantice la ejecución y cumplimiento de las promesas antes aprobadas por la sociedad para su bienestar.

Otra cosa que no se encontró en ninguna circular de la Registraduría, como en las propias leyes o sentencias, es sobre el plagio que pueda presentarse en el eventual caso en que un candidato tenga el mismo programa de gobierno de otro municipio o departamento, y mucho menos la responsabilidad de dicha actuación, más aún, desde el punto de vista de las necesidades, consideramos imposible que municipios o departamentos tengan necesidades homogéneas, lo cual da cabida a que se reproduzcan sin ninguna justificación promesas electorales de otros sitios. 


\section{CASO CONCRETO}

Al partir de la premisa constitucional contemplada en el artículo 259, tanto de los desarrollos normativos y jurisprudenciales del voto programático como de la revocatoria del mandato y las directrices de la Registraduría Nacional del Estado Civil, decidimos escoger como caso de observación el tema de la Alcaldía de la capital del país cuando llegó al poder el señor Gustavo Francisco Petro Urrego para el periodo de gobierno 2012-2015.

Las razones que nos motivaron a seleccionar la de Bogotá, D.C. entre tantas alcaldías pueden resultar por demás obvias:

a) Por la importancia que tiene la capital del país para cualquier lectura que se pretenda realizar a nivel de estudios políticos.

b) Porque nos evitaba la movilidad o desplazamiento para observar fenómenos como protestas, marchas, incluso porque de sus decisiones y como residentes de la ciudad seríamos afectados o beneficiados de su programa de gobierno.

c) Debido a la calidad del sujeto político, toda vez que tiene una trayectoria en escenarios públicos y jurídicos al haber sido integrante del grupo guerrillero M19, Concejal de Zipaquirá para los periodos 1984-1986, después de la constituyente de 1991 fue representante a la Cámara por el departamento de Cundinamarca así como también para Bogotá y 
volvería a repetir escaño en el año 2002. Para el año 2006 fue Senador de la República de Colombia y en el año 2010 candidato a la presidencia de Colombia.

\subsection{Hacla una lectura No SUbJetivizada EN EL CASO}

Hasta aquí y antes de empezar pueden existir más razones o muchas desavenencias en torno a nuestra exposición de la escogencia del caso para observar, pero consideramos un buen laboratorio de observación los tres argumentos anteriormente expuestos para contrastar nuestra parte dogmática a la realidad jurídica y social que tiene un territorio como Bogotá, y aunque no realizamos movilidad por cada localidad que comprende el Distrito Capital, nos bastó como ruta a seguir su programa de gobierno inscrito, y los episodios registrados por la Registraduría Nacional del Estado Civil en su página web.

Se deja de lado el sufrimiento social de los cinturones de pobreza que rodean la ciudad, toda vez y como ya se explicó, entendemos y fue sustento para describir los procesos democráticos en que de manera lamentable los menos favorecidos son los más despreciados, cuando no son etiquetados para fines políticos como justificatorios de gloriosos proyectos -reificados- y después pasan a ser ignorados. Tampoco tuvimos presente las opiniones de los sectores industriales, los conceptos de antiguos alcaldes, posibles 0 potenciales candidatos a ejercer ese tipo de cargo, o dirigentes miembros del sub-sistema de la política por una razón específica, y es que tampoco 
buscábamos tomar inclinación por ningún movimiento, grupo o ideología política, pues de hacerlo todo el trabajo se prestaría para el servicio de un propósito específico y perdería la sustentación académica.

Si bien es cierto no consideramos este tipo de empirismo en un primer orden dentro de la investigación, nos arriesgamos a que a partir del conocimiento académico desarrollado tengamos la experiencia para criticar de manera lógica nuestra hipótesis, estando con ello sujetos a falsearla, refutarla o validarla sin aceptar una posición totalizante del fenómeno político-jurídico, así como tampoco justificaremos la pasividad de la sociedad la cual, se dice, es dueña de la soberanía dentro de un territorio, tal como nos lo han hecho creer, incluso la democracia misma.

En estos términos entraremos a criticar tanto el programa de gobierno y el mandato a seguir como el desarrollo del mismo, para así determinar si el instituto de la revocatoria del mandato realmente funciona cuando existe insatisfacción o incumplimiento del mandato, o si estamos ante políticos eficientes que gobiernan según sus máximas reglas. 


\subsection{LA PROMESA DE GOBIERNO. MANDATO A SEGUIR}

Como discurso político que es una promesa de gobierno, debe existir en ese tipo especial de comunicación temas álgidos o, en nuestras palabras, necesidades que tenga la sociedad capitalina en específico. Ahora bien, al partir del hecho de que ganó las elecciones, y fue electo Alcalde de Bogotá para el periodo 2012-2015, nos apoyamos en su programa de gobierno ${ }^{33}$.

Una vez leído el programa de gobierno podemos entender por qué en la mayoría de sus intervenciones, que los medios de comunicación seguían, hablaba de una "Bogotá Humana". Entonces, para comprender el título publicitario o slogan de lo que sería todo su plan a seguir durante su mandato, analizamos su programa de gobierno de la siguiente manera:

- Encontramos un núcleo general de premisas negativas que al parecer la sensibilidad del político encontró antes de tomar posesión como Alcalde de Bogotá, las cuales podemos enmarcar de la siguiente manera:Excluyente y segregador.

- Desarrollo social.

- Desigualdad.

- Sacrificio.

${ }^{33}$ Disponible en: http://www. alcaldiabogota.gov.co/sisjur/normas/verNormaPDF?i=45478 (última actualización de la página web: miércoles 13 de agosto de 2014). 
- Después, en el mismo programa de gobierno, pudimos observar las bases de lo que sería su estructura para desarrollar todo su gobierno, esto es, el político iría por unos temas concretos "no tratados antes", pero de enorme significado para la ciudad.Seguridad alimentaria.

- Recursos naturales.

- Medio ambiente.

a) Siendo un poco más específico, el político se adentró en los problemas que perturban a la mayoría de los habitantes de Bogotá:

- Transporte.

- Vías de acceso.

- Servicios públicos.

- Salud.

- Inseguridad.

- Discriminación.

- Empleo formal.

Al parecer quiso ir más allá de solo detectar problemas; encontró además los obstáculos de gobernabilidad de mandatarios anteriores:

- Transmilenio.

- Manejo de las basuras.

- Problemas por la mala prestación del servicio de la salud. 
b) Descrito no sólo el estado de cosas sino "encontradas las necesidades que imaginamos socializó con la comunidad capitalina", o en palabras de nuestra investigación, de manera arbitraria, clasificó y determinó lo importante para ser tratado, o con base en la crítica de anteriores alcaldes organizó no solo su discurso político sino que puso como fundamento un escenario apartado de cualquier pretensión digna para llamase asimismo su gobierno una "Bogotá Humana".

c) A continuación encontramos las bases de su contrato/mandato a seguir, donde aquellos que lo eligieron depositaron sus expectativas en él, y quienes no, al parecer de la Corte Constitucional, no deberían sentirse aislados de la democracia participativa, comoquiera que si existía una inconformidad general también estos podían remover a su dirigente, el cual, por más que no fuera de su simpatía, no era necesario ser opositor político, sino encontrarse insatisfechos por su gestión para empezar un año e intentar promover la revocatoria del mandato.

Aunque para la Corte Constitucional los contradictores políticos no se sabe dónde quedaron cuando reglamentaron la revocatoria del mandato, a nivel dogmático ya expusimos cómo el político que llega al poder hace público su rechazo o crítica a sus antecesores, por lo mismo cíclico que se torna la situación, existirán políticos no partidarios de sus promesas o forma de gobernar, y ya en el campo de lo que se 
comprometió a hacer observamos en su programa de gobierno unos objetivos para el periodo 2012-2015:

- Combatir la segregación.

- Construir una ciudad.

- Combatir la corrupción.

Al parecer, esta lectura arroja el esquema general de las promesas electorales; se la pasará "combatiendo" 34 y al final de su periodo "construirá una mejor ciudad", de lograrse, dejaría a los próximos políticos un escenario bastante organizado y "muy" humano. Ignoramos en su gestión como el burgomaestre evito la corrupción ${ }^{35}$, pero entendemos por la misma lógica de la del sub-sistema político que los mayores generadores de segregación son los políticos mismos, y la sociedad está obligada a tomar partido por un color, una ideología o simplemente se desinteresan y se enfocan mejor en atender sus necesidades a manos propias y no esperando un político-mesías reivindicador de la sociedad y sus males.

${ }^{34}$ En este punto podemos encontrar una similitud en el discurso que el entonces grupo guerrillero M19 tenía en su proyecto político descrito en páginas anteriores. Al elaborar dicho paralelo surgen dos alternativas; la primera consiste en que dicha ideología por más de desintegrado el grupo insurgente ha perdurado en algunos de sus excombatientes. La segunda, nos orienta a pensar si realmente la vida social cambio después de aquella constituyente de 1991 y, 23 años después de actividad política los escenarios de necesidades sociales son, guardando las proporciones asimétricamente iguales. Es decir, las cosas no cambiaron y la sociedad continúa en desprecio. Los únicos mejorados fueron los integrantes de ese movimiento que ahora se encuentran en cargos públicos, pensionados del Estado o empresarios individuales

35 http://www.elespectador.com/noticias/bogota/puede-roben-esquinas-petro-articulo-509614 última actualización: miércoles 13 de agosto de 2014 
Frente a la insignia de la "ciudad que vaya a construir" encontramos un punto crítico a reflexionar, ni la misma Asamblea Nacional Constituyente, los propios legisladores, y mucho menos la Corte Constitucional se han percatado, y es el tema de los proyectos que vienen ejecutándose de gobiernos anteriores, de quién sería eventualmente el mérito porque una pasada propuesta de gobierno tuvo que haber salido, del gestor, ejecutor, de quién entrega el proyecto, etc., además qué parámetros existen entre los sub-sistemas para reconocer lo trazado que en su momento pudo haber generado comentarios de todo tipo, y cómo un buen proyecto, independiente de la ideología o corte político, qué medidas de conservación se implementarían para el bienestar general y no acabarlo o deformarlo por ser idea de un opositor.

Alejados del presupuesto destinado para proyectos de grande envergadura para el bienestar general y las políticas macroeconómicas que en últimas deciden si un proyecto es viable, o que por costos tiene que ser desvirtuado, nos planteamos otro obstáculo y es el de por qué ni la misma Asamblea Nacional Constituyente, ni los legisladores, ni la Corte Constitucional y mucho menos los políticos que van y vienen, han formulado que una cosa es llegar a un cargo de elección popular donde ya el dirigente de turno tiene que empiezar a desarrollar lo prometido, y otra es seguir con los procesos de gobernabilidad que jamás se detienen. 
Asuntos que cada entidad tiene (peticiones, quejas, reclamos, denuncias, eventos naturales tales como cambios de clima, epidemias, etc.) no son tenidos en cuenta al momento de iniciar un mandato. Aclaramos que aquí no estamos hablando de cláusulas exorbitantes de responsabilidad del mandato político, sino que se deja de lado los procesos de gobernabilidad como constante y que el político recibe todo ya en marcha.

d) Finalmente, describimos lo que en concreto el político se comprometió a hacer. Aclaramos que las promesas de gobierno son bastantes amplias y otras con bastante argumentación donde el posesionado como alcalde se obliga a realizar, pero para no extendernos ni trascribir (en extenso) sintetizamos los aspectos generales, no sin dejar anotado que el lector interesado lo puede buscar en la página web referida si desea una mayor comprensión de la totalidad de promesas a las que puede llegar un político. 


\section{ESTRATEGIAS Y PROGRAMAS PARA LA POLÍTICA PÚBLICA}

\section{1 [Ciudad incluyente y para la gente]}

1. Garantía del consumo mínimo vital de agua y disminución gradual de tarifas de servicios públicos.

2. Profundizar el programa de salud a su hogar.

3. Profundizar la revolución educativa, mayor acceso y calidad.

4. Abaratar la alimentación en Bogotá.

3.2 [Todo el apoyo para la economía popular]

3.3 [EI centro ampliado, el corazón de la ciudad y su área metropolitana]

\section{4 [Recuperación del centro ampliado]}

1. Manejo de los bordes urbanísticos de la ciudad.

2. Crear el área metropolitana.

3. Democratizar la actividad cultural.

3.5 [Recuperar la movilidad en las arterias vitales de la ciudad] 


\section{6 [Lo ambiental no es casual, es vital]}

1. Basura Cero.

2. Gestión integral de residuos sólidos y desechos industriales.

3. Estimulación del reciclaje.

\section{7 [Gestión transparente y sin corrupción]}

\section{8 [Combate frontal al crimen organizado]}

1. Promover el desarme ciudadano.

\section{9 [Más democracia, con planeación y presupuesto participativo]}

De manera breve podemos concluir que encontramos aproximadamente 9 promesas generales, algunas con sus desarrollos específicos y otras tratadas a nivel general; la mayoría de los verbos empleados en infinitivo hacen suponer al elector que en verdad el político está comprometido con lo que determinó necesita la sociedad de su jurisdicción. Frente a lo anterior, en teoría, de las obligaciones existe una cláusula en derecho civil que dice: nadie está obligado a lo imposible. ¿Será que todo lo anteriormente señalado en un periodo tan breve como en nuestro caso el de un alcalde ${ }^{36}$, sí es posible cumplir a cabalidad cada promesa que genera expectativas en la comunidad?

${ }^{36}$ Y así a futuro se plantee la posibilidad de ser reelegido, cosa que en ningún momento se está proponiendo. 
De ser negativa la respuesta entonces, el propio dirigente político -porque en este punto ya se encuentra investido de autoridad pública- no parece tener responsabilidad política por lo prometido, toda vez que en últimas termina haciendo lo que mayor impacto le genere a su imagen. En el mismo sentido, pareciera que de hacer sólo algunas cosas durante su gestión, son unos pocos los que se terminan beneficiando, y a la postre no busca el político un bienestar general sino una reivindicación a su propio nombre o movimiento en aras de haber tenido esa sensación de poder, con lo cual buscará volver a tener el control con diferente maquinaria política llevando a cabo las mismas estrategias.

\subsection{DesarRollo del MANDATO, PROBlematizaciones y GeStión de LA REVOCATORIA DEL MANDATO}

Cuando el alcalde de Bogotá empezó a desarrollar su programa, los medios de comunicación mostraban un dirigente inmerso en una investigación preliminar del ente de control, Procuraduría General de la Nación aproximadamente desde enero de 2013, por improvisación en su programa "Basura Cero". Para la misma fecha la Registraduría había recibido firmas ciudadanas de quienes no se encontraban conformes con la gestión durante el primer año del burgomaestre. Como lo que nos concierne es la revocatoria, omitiremos el tema disciplinario. 
El 18 de abril de $2013^{37}$ fue radicada ${ }^{38}$ ante los Registradores Distritales del Estado Civil, el acta de entrega de las 628.500 firmas y el memorial que solicitaba convocar a pronunciamiento de la ciudadanía de Bogotá sobre la revocatoria del señor Gustavo Francisco Petro Urrego, toda vez que se había adjuntado el porcentaje de rúbricas requeridas en la ley para iniciar dicho trámite.

Seguido a lo anterior, el 26 de abril de 2013 la Registraduría entró en la fase técnica contando los folios donde se encontraban el apoyo de dicha solicitud en 32.220 formularios para su contraste con el Censo Electoral y el respectivo estudio grafológico. Del mismo modo se dejó la posibilidad para que el Alcalde también pudiera verificar el contenido de las firmas asesorado por su equipo de defensa ${ }^{39}$, pero de manera posterior al estudio que realizara la Registraduría, lo anterior tenía como propósito brindarle al burgomaestre todas las garantías en la solicitud de revocatoria iniciada por algunos ciudadanos de la Capital.

El 17 de mayo de 2013 el Director del Censo Electoral, tomando como fundamentos la Resolución 6254 de 2002 y la Circular 174 de 2013, le manifestó ${ }^{40}$ a los Registradores Distritales del Estado Civil prorrogar por un

${ }^{37}$ http://www.registraduria.gov.co/IMG/pdf/acta entrega firmas 18 abril.pdf (última actualización, agosto 14 de 2014).

${ }^{38} \mathrm{http}: / /$ www.registraduria.gov.co/IMG/pdf/certificacion reg distritales 19 abril.pdf (última actualización, agosto 14 de 2014).

${ }^{39} \mathrm{http}: / /$ www.registraduria.gov.co/IMG/pdf/FLAVIO AUGUSTO RODRIGUEZ0001.pdf (última actualización, agosto 14 de 2014). 
término superior a los 30 días consagrados para la verificación de cada proceso comoquiera que era notable el registro de firmas y su cotejo tomaría más tiempo del establecido en la ley.

Fue así como el 7 de junio de 2013 los Registradores Distritales del Estado Civil, mediante Resolución $766^{41}$ de junio 7 de 2013, certificaron el cumplimiento de los requisitos legales y constitucionales para convocar a votaciones con fines de revocatoria de mandato en Bogotá, D.C.; en la resolución en su parte considerativa le exponen al señor Alcalde de Bogotá:

- Identificación de los ciudadanos que promovieron la revocatoria del mandato.

- Número de sufragios por medio de los cuales el Alcalde de Bogotá llegó a ejercer el cargo, los cuales en total fueron 723.157 votos en las elecciones de octubre 30 de 2011.

- Explicación contentiva de la solicitud de la revocatoria del mandato por parte de algunos ciudadanos con un número total de 628.500 firmas.

- Explicaron la operación matemática de donde se extrae el $40 \%$ del censo electoral, que en el caso concreto era necesario un total de 289.263 firmas requeridas para solicitar la revocatoria del mandato atendiendo al artículo $1^{\circ}$ de la Ley 741 de 2002.

\footnotetext{
40 http://www.registraduria.gov.co/descargar/revocatoria-alcalde-petro170513.pdf (última actualización, agosto 14 de 2014)

41 http://www.registraduria.gov.co/descargar/resolucion 766 de 2013.pdf (última actualización, agosto 14 de 2014)
} 
Ahora bien, en la parte resolutiva le manifestaron que se aprobaba la solicitud de convocar a elecciones para revocarle el mandato al señor Alcalde de Bogotá, y en igual sentido manifestaron los recursos de ley con que contaba, esto es, reposición ante los Registradores que profirieron dicha resolución, y apelación ante el Registrador Nacional del Estado Civil.

De todo lo anterior y durante el proceso administrativo señalado el Alcalde de Bogotá, en conjunto con su abogado, presentaron varios derechos de petición donde requerían información completa, explicaciones, etc. En últimas, la Registraduría contestaba las solicitudes, incluso el Secretario Privado del despacho del señor Alcalde había solicitado una reunión ${ }^{42}$ con expertos de otros países para que revisaran el caso de la revocatoria del mandato, pero en su debida oportunidad el Registrador encargado se negó a dicha petición debido a que la solicitud de revocatoria se encontraba en términos y por cuestiones de trasparencia la entidad no accedía a ese tipo de eventos.

El 7 de junio de 2013 el Alcalde de Bogotá presentó acción de tutela contra la Registraduría Nacional del Estado Civil y la Registraduría Distrital del Estado Civil ante el Tribunal Administrativo de Cundinamarca, Sección Tercera, Subsección A (Rad. 2013-796-00). Los motivos que llevaron a solicitar amparo de sus derechos fundamentales al debido proceso versaron sobre una vía de

42http://www.registraduria.gov.co/IMG/pdf/SOLICITUD Y RESPUESTA EXPERTOS INTER NACIONALES.pdf (última actualización, agosto 14 de 2014) 
hecho administrativa ${ }^{43}$ producida durante el proceso de verificación de las firmas, toda vez que con fundamento en el artículo $40^{44}$ del Código de Procedimiento Administrativo y de lo Contencioso Administrativo (CPACA), la Registraduría restringió la posibilidad de que el Alcalde verificara las firmas de quienes solicitaron se iniciara la revocatoria, bajo el entendido que para los actos previos de constatar las firmas no existían recursos, decisión contemplada en la Resolución 766 de junio 7 de 2013, y fue justamente a partir de ahí que a juicio del Tribunal y del accionante se vulneró el derecho fundamental a la defensa del tutelante, en consonancia con el CPACA, artículos $1^{\circ}, 2^{\circ}$ y 34

Para finalizar, el a quo estimó aclarar en atención a los recursos que le permiten al burgomaestre atacar la certificación de la revocaría del mandato "no son idóneos para la garantía de los derechos fundamentales de la parte accionante, (...) en el reducido término de diez días" (Sentencia de Tutela del Tribunal Administrativo de Cundinamarca. Rad. 2013-796-00. M.P.: Alfonso Sarmiento Castro), toda vez que si la Registraduría se había demorado aproximadamente un mes, los términos conferidos por la ley resultan ineficientes y atentatorios de los derechos políticos y constitucionales del Alcalde.

\footnotetext{
43 Entendida según Sentencia T-995 de 2007 de la Corte Constitucional, como aquella irregularidad que "se produce cuando quien toma una decisión, sea ésta de índole judicial o administrativa, lo hace de forma arbitraria y con fundamento en su única voluntad, actuando en franca y absoluta desconexión con el ordenamiento jurídico".

${ }^{44} \mathrm{El}$ interesado contará con la oportunidad de controvertir las pruebas aportadas o practicadas dentro de la actuación, antes que se dicte una decisión de fondo.
} 
Así las cosas, la Sala de Decisión del Tribunal Administrativo de Cundinamarca, Sección Tercera, Subsección A, resolvió en su sentencia ${ }^{45}$ de tutela dejar sin efectos la Resolución 764 de junio 17 de 2013, "Por la cual rechaza por improcedentes los recursos de reposición y apelación (...)", y la Resolución 766 de junio 7 de 2013, "Por la cual se certifica el cumplimiento de los requisitos legales y constitucionales para convocar a votaciones con fines de revocatoria de mandato en Bogotá D.C.", además ordenó a la Registraduría Nacional del Estado Civil y Registraduría Distrital del Estado Civil "trasladen el informe de verificación de las firmas a la defensa del Alcalde, junto con sus soportes completos". De igual forma, ordenó al accionante a su costa que entregara a la Registraduría "relación de 10 peritos grafólogos (...)" para que se garantice la defensa del político en condiciones similares a las que tuvo la Registraduría para comparar firmas en un término de 15 días hábiles. Finalmente, ordenar a la Registraduría, una vez vencido ese plazo, se pronuncie sobre si se cumplen los requisitos que certifiquen la solicitud a la revocatoria.

Mediante Auto ${ }^{46}$ la Registraduría Nacional del Estado Civil acató la orden del Tribunal, del mismo modo, el 2 de julio de 2013 la Registraduría formuló apelación ${ }^{47}$ de la sentencia argumentando sus fases técnicas basadas en

${ }^{45} \mathrm{http}: / /$ www.registraduria.gov.co/IMG/pdf/tutela petro.pdf (última actualización, marzo 26 de 2013).

${ }^{46}$ http://www.registraduria.gov.co/IMG/pdf/AUTO CUMPLIMIENTO TUTELA REVOCATORI A GUSTAVO PETRO.pdf (última actualización, 14 de agosto de 2014).

47 http://www.registraduria.gov.co//MG/pdf/impugnacion fallo tutela.pdf (última actualización, 14 de agosto de 2014). 
pronunciamientos de la Corte Constitucional. Continuando con lo dicho por el juez de tutela, se realizaron los procedimientos donde el Alcalde pudo trabajar con los grafólogos solicitados, los cuales el 22 de julio de 2013 entregaron informe de su experticia ${ }^{48}$ ante la Registraduría.

Una vez analizados los formularios y cotejadas las firmas por expertos grafólogos en aras de garantizar el derecho de contradicción al Alcalde, la Registraduría Distrital del Estado Civil, mediante Resolución $1019^{49}$ de julio 31 de 2013 nuevamente certifica los requisitos legales para que se inicie la solicitud de revocatoria del mandato al burgomaestre capitalino, comoquiera que se lograron identificar 355.353 firmas las cuales no presentaban ningún obstáculo para iniciar el trámite de la revocatoria, resultado que superó el $40 \%$ exigido para que se pudiera certificar dicha solicitud, toda vez que el mínimo establecido según el Censo Electoral estaba en 289.262 votos.

Así las cosas, se aprobaba la solicitud de convocatoria a elección de revocatoria del mandato al señor Alcalde de Bogotá. En igual sentido, le manifestaron los recursos de ley con que contaba, esto es, el de reposición ante los Registradores que profirieron dicha resolución, y de apelación ante el Registrador Nacional del Estado Civil. En lo que sigue, el 8 de agosto de 2013

48 http://www.registraduria.gov.co/IMG/pdf/0001INF DISTRITAL.pdf (última actualización, 14 de agosto de 2014).

49 Disponible en: http://www.registraduria.gov.co/IMG/pdf/Resolucion 1019 de 2013 2.pdf (última actualización, 14 de agosto de 2014). 
se notificó ${ }^{50}$ personalmente al señor Alcalde de Bogotá, Gustavo Francisco Petro Urrego. Como era de esperarse, se interpusieron los recursos contemplados, pero mediante Resolución 1209 de $2013^{51}$ se confirmó la Resolución 1019 de julio 31 de 2013.

El 5 de noviembre de 2013 el Registrador Nacional avocó conocimiento para conocer del recurso de apelación impetrado por el Alcalde de Bogotá, y mediante Resolución $13806^{52}$ de diciembre 17 de 2013 se resolvió el Recurso de Apelación interpuesto contra el acto administrativo (Resolución № 1019 de 2013, proferido por la Registraduría Distrital del Estado Civil), confirmándola en todas sus partes.

Agotados los recursos de la actuación administrativa, mediante Resolución ${ }^{53}$ 008 de 2014 los Registradores Distritales del Estado Civil avocaron conocimiento para convocar a los ciudadanos a la revocatoria del mandato del Alcalde mayor de Bogotá para el día 2 de marzo de 2014. Como era de esperarse, se presentaron fenómenos jurídicos que nos recuerdan la manipulación que el sub-sistema de la política puede hacer sobre el subsistema del derecho.

\footnotetext{
50http://www.registraduria.gov.co/IMG/pdf/Notificacion personal res 1019 de 2013.pdf (última actualización, 14 de agosto de 2014).

${ }^{51} \mathrm{http}: / /$ www.registraduria.gov.co//MG/pdf/notificacion-res1209-2013.pdf (última actualización, 14 de agosto de 2014).

52 http://www.registraduria.gov.co/IMG/pdf/Resolucion 13806 2013.pdf (última actualización, 14 de agosto de 2014)

${ }^{53}$ http://www.registraduria.gov.co/IMG/pdf/RESOLUCION 008 DE 2014.pdf (última actualización, 14 de agosto de 2014)
} 
Tales acontecimientos los enunciamos solo con el propósito de indicarlos para exponer las trabas que durante el proceso, y más que todo finalizando, se presentaron en el trámite de la certificación para la revocatoria del mandato:

a) Incidente de desacato de la tutela interpuesta por el señor Alcalde de Bogotá calendado el 29 de julio de 2013.

b) Decisión del Tribunal Administrativo de Cundinamarca, de agosto 21 de 2013, por medio de la cual niega el incidente de desacato.

c) Demanda de acción popular con solicitud de medida cautelar a fin de evitar la expedición de la resolución que convoca a votaciones para revocar el mandado.

d) Diversos derechos de petición presentados donde se solicita documentación sobre cada procedimiento realizado por la Registraduría.

e) Decisión de octubre 28 de 2013 del Tribunal Administrativo de Cundinamarca (Rad. 2013-1652. M.P.: Carlos Enrique Moreno Rubio) sobre la acción popular donde se niega la solicitud de decreto de medidas cautelares.

f) Solicitud de misión de observación internacional Uniore, de diciembre 18 de 2013.

g) Solicitud de misión de observación internacional UNASUR, de diciembre 18 de 2013. 
h) Demanda ante la Comisión Interamericana de Derechos Humanos $\mathrm{CIDH}$ - para que ordene como medida cautelar, suspender la investigación realizada por la Procuraduría ${ }^{54}$.

i) Demanda ante el Consejo de Estado cuyo medio de control fue el de acción de nulidad y restablecimiento del derecho presentado en la Sección Segunda de dicha Corporación para que se declararan nulos los actos administrativos que lo habían inhabilitado.

En igual sentido, se modificó en varias oportunidades la fecha en que se convocaría a votaciones para revocar el mandato, tal como podemos observarlo en la Resolución $0183^{55}$ de 2014 , donde se fijó para el 6 de abril de 2014

\section{4. ¿SE LLEVÓ A CABO LA REVOCATORIA?}

Tal como indicamos anteriormente, el Alcalde de Bogotá no solo se encontraba inmerso en un proceso de revocatoria del mandato, sino además estaba en curso una investigación disciplinaria por parte de la Procuraduría General de la Nación por los 3 días de caos en el tema de las basuras en Bogotá. Fue así como la Sala Disciplinaria de la Procuraduría General de la Nación, mediante

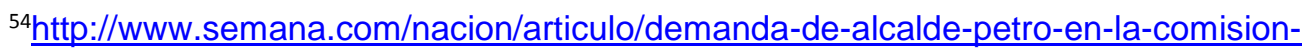
interamericana-de-derechos-humanos/362681-3 (última actualización, 14 de agosto de 2014) y http://www.colectivodeabogados.org/nuestro-trabajo/noticias-cajar/Radicada-denunciacontra-el-Estado

55 http://www.registraduria.gov.co/IMG/pdf/res-0183-2014.pdf (última actualización, 14 de agosto de 2014)
} 
fallo de única instancia de diciembre 9 de 2013 (Rad. IUS 2012-44748, IUC O 2013-661-576188) sancionó con destitución e inhabilidad por 15 años al burgomaestre capitalino.

Una vez agotados los recursos de ley, el 13 de enero de 2014, la Sala Disciplinaria ratificó su decisión y ordenó se libraran las comunicaciones al Presidente de la República para que ejecutara la orden con fundamento en el Decreto 1421 de 1993, y tal como se presentó en el trámite de la revocatoria, empezaron a gestionarse un sin número de recursos jurídicos para que se detuviera dicha orden, pero que en últimas no prosperaron.

Así las cosas, el Presidente de la República decretó la destitución del Alcalde Mayor de Bogotá, y mediante Decreto 570 de marzo 20 de 2014, encargó de manera transitoria, mientras se adelantan las elecciones para elegir nuevo Alcalde, al señor Rafael Pardo Rueda. Por lo anterior, la Registraduría Distrital del Estado Civil mediante Resolución $340^{56}$ del 20 de marzo de 2014 resolvió: "Dar por terminado, por carencia de objeto, la consulta popular, con fines de revocatoria del mandato del señor Gustavo Francisco Petro Urrego quien ostentaba la calidad de Alcalde Mayor de Bogotá D.C.".

${ }^{56} \mathrm{http}: / /$ www.registraduria.gov.co/IMG/pdf/Res 3402014 terminacion revocatoria petro.pdf (última actualización, 14 de agosto de 2014) 
Como el alcalde Petro previo había radicado demanda ante la $\mathrm{CIDH}$, la Comisión Interamericana de Derechos Humanos, mediante resolución 5 de 2014 profirió la medida cautelar número $374-13$ del 18 de marzo de $2014{ }^{57}$ por más que el Estado Colombiano el 10 de enero de 2014 presentara informe explicaba las funciones constitucionales del Procurador General de la Nación para disciplinar a funcionarios elegidos por elección popular. En la decisión del organismo internacional se desprende con especificidad:

“(...) [L]a Comisión solicita al Gobierno de Colombia que suspenda inmediatamente los efectos de la decisión de 9 de diciembre de 2013, emitida y ratificada por la Procuraduría General de la Nación el 13 de febrero de 2014, a fin de garantizar el ejercicio de los derechos políticos del señor Gustavo Francisco Petro Urrego y pueda cumplir con el periodo para el cual fue elegido como Alcalde de la ciudad de Bogotá D.C., el 30 de octubre de 2011, hasta que la CIDH se haya pronunciado sobre la petición individual P-1742-13 (...)” (Comisión Interamericana de Derechos Humanos, 2014)

El problema se la destitución se volvió más agudo cuando la Canciller del gobierno Colombiano manifestó que no se acataría dicha orden ${ }^{58}$ como quiera que para el entendido del presidente Juan Manuel Santos, prevalecía la

\footnotetext{
${ }^{57}$ http://www.oas.org/es/cidh/decisiones/pdf/2014/MC374-13-ES.pdf (última actualización, 14 de agosto de 2014)

${ }^{58} \mathrm{http}: / /$ www.semana.com/nacion/articulo/caso-petro-que-implica-no-acatar-la-sugerenciade-la-cidh/381258-3 (última actualización, 14 de agosto de 2014)
} 
Constitución del país a los tratados internacionales ${ }^{59}$, por más que para inicios del año 2014 había dicho que respetaría las decisiones de la CIDH. Lo anterior no fue obstáculo para que presentara demanda en acción de nulidad y restablecimiento del derecho ante el Consejo de Estado la cual fue radicada bajo el expediente 110010325000-2014-00360-00 y número interno 11312014 donde la parte demandada era la Nación-Procuraduría General de la Nación.

La Corporación de lo Contencioso Administrativo, con ponencia del magistrado Gerardo Arenas Monsalve mediante auto del 14 de mayo de 2014 se pronunció sobre las medidas cautelares solicitadas en la demanda y accedió a otorgarlas, es decir, ordenó que se suspendiera la decisión disciplinaria de la Procuraduría y volviera el recién destituido alcalde a su cargo lo cual se logró con éxito y el burgomaestre continuo ejerciendo su administración dada la garantía mientras la demanda continuara su curso normal dentro del proceso.

Lo que quedó en entredicho por la fecha en que el burgomaestre volvió a su cargo era la solicitud de revocatoria del mandato habida cuenta que mediante resolución 0340 del 20 de marzo de 2014 la Registraduría Distrital del Estado Civil había determinado dar por terminado continuar con la revocatoria del mandato en contra del alcalde de Bogotá y jurídicamente no es dable volver a

\footnotetext{
${ }^{59} \mathrm{http}: / /$ www.semana.com/nacion/articulo/cidh-caso-petro-venezuela-como-temasclave/381492-3 (última actualización, 14 de agosto de 2014)
} 
iniciar otro proceso de revocatoria. Un aspecto político que aquí salto a la vista era el proceso de elecciones presidenciales el cual se encontraba tan dividido que el Presidente de la República al intentar buscar coalición había hecho un llamado a otros movimientos o partidos para que lo respaldaran y según se pudo observar, el movimiento político del alcalde decidió apoyarlo.

Ello dejo una extraña sensación en la ciudadanía al ver cómo antes, integrantes del gobierno nacional se encontraban antes de elecciones en una completa oposición a la manera en que se estaba gobernando la ciudad de Bogotá y ahora recibían apoyo justamente del alcalde y su movimiento. Aunado a lo anterior el sub-sistema jurídico garantizo los derechos políticos del dirigente pero desplazo un mecanismo constitucional de revocatoria a un segundo plano a sabiendas que también ahí se encontraban derechos políticos de los Bogotanos en aras de ser atendidos por la aparente insatisfacción que tenían por la manera de administrar la capital del país. 


\section{ConCLusiones}

Una vez terminada la investigación podemos reunir una serie de ideas en torno a los resultados finales que se alcanzaron con independencia de las que durante todo el recorrido hicimos en los distintos apartados. Como primera medida expondremos las conclusiones generales, y finalmente dedicaremos los últimos párrafos a describir si nuestra hipótesis se desvirtuó o se validó en el caso concreto.

Una vez enfocados en un campo específico, como lo es Colombia y su premisa constitucional configurada en el artículo $1^{\circ}$, nos valimos de esta para desarrollar a partir de enunciados teóricos los contenidos de Estado, como primera manifestación del sub-sistema de la Política y dentro del cual los sujetos que se mueven en éste son seres con unas reglas propias y fines claros; también nos referimos a la sociedad como gran marco de referencia donde se producen todo tipo de fenómenos, en donde el individuo y la comunicación con los demás son la base misma de todo fundamento social; sin embargo, nos concentramos en el discurso de las necesidades particulares. Finalmente encontramos en el sub-sistema del Derecho ese conjunto de normas que legitiman a los funcionarios en su cargo, reprochan o limitan las actuaciones de las instituciones, e incluso generan expectativas a la sociedad. 
Entendimos y fue nuestra gran apuesta en el diseño de la presente investigación, una vez expuestas las anteriores condiciones de cada subsistema -política y derecho-, dentro del sistema social, a partir de las estructuras que estos poseen, de sus diferencias y teniendo en cuenta la interpenetración entre ellos, justifican la democracia de lo cual nos resultó un nuevo sub-sistema, que a nuestro parecer surge de éstos.

Al no encontrar que las explicaciones racionalistas o empiristas que definen la democracia en los países de occidente se acoplaran a nuestra realidad entonces, con fundamento en la interpenetración de los sub-sistemas, argumentamos la estructura del sub-sistema de la democracia, el cual se vale de dos sub-sistemas (el del derecho y de la política) para surgir por breves espacios de tiempo como son las campañas electorales y los comicios. Después de esto desaparece justamente porque al tener sus bases prestadas de otros subsistemas, cada sujeto que pertenece al grupo vuelve a sus asuntos continuando así su vida. Es por ello que llegamos a postular la afirmación de que no se vive en democracia.

También nos referimos a las necesidades de la sociedad y las acoplamos como elemento propio, sin que ello fuera ajeno a otros sub-sistemas toda vez que cuando el político accede al poder, toma como referente la angustia social frente a las necesidades presentes; cosa distinta sucede para el Derecho, el cual sólo se interesa por la legitimidad de los procesos incluso, ya en un plano más normativo, crear crea un mandato con obligaciones políticas para que 
dichas necesidades sí sean atendidas, pero en últimas es cada sub-sistema el encargado de clasificar lo que entiende por necesidad, y asimismo plantea cómo solucionarla sin consultar o socializar con la propia comunidad. Por lo anterior, desvirtuamos esa tradicional lectura de la democracia, la cual nos traducía que el poder se encontraba en manos del pueblo, o que la soberanía reside en el pueblo.

Más bien los hallazgos revelan un desprecio hacia el padecimiento social, en especial frente al sujeto por parte de los sub-sistemas en comento, en sus diversos matices, empezando porque el sub-sistema de la democracia tal como la percibimos no acepta la pluralidad ni las diferencias sino que las marca más, toda vez que será el político quien gobierna para sí mismo o para los suyos y se valdrá de todos los instrumentos jurídicos para permanecer en el poder, mientras los grupos de oposición, también políticos, se valen de los despreciados mientras les llega el turno para acceder al poder y lograr así legitimarse por las vías jurídicas por más que exista dentro de la democracia un mandato a seguir.

Por su parte, el sub-sistema de la política desprecia a la sociedad, al escoger de manera arbitraria las necesidades que atenderá; en igual sentido se vale del mismo discurso para no comprometerse a nivel jurídico sino a partir de sus propias reglas, incluso al momento de encontrar obstáculos descarga su responsabilidad en la oposición. También existe el desprecio una vez terminado los escrutinios, dado que vuelve todo a seguir el curso normal 
mientras, como es lógico, la burocracia ya estudiada por diversos autores permea las instituciones para pagar los costos que trajo consigo la campaña electoral.

Aun cuando todo se da por beneficioso para unos pocos, se esperaría que el sub-sistema del derecho obstaculizara los fenómenos del sub-sistema político y garantizara el cumplimiento del mandato, sin embargo entendemos que el mismo Derecho ayuda a la legitimación del político para acceder al poder, pero también le facilita las herramientas para que éste pueda defenderse de cualquier contingencia. Acciones de tutela, derechos fundamentales, recursos judiciales e instancias internacionales son empleadas en este caso no tanto para el uso de los individuos sino para salvaguardar sus derechos particulares.

Otro aspecto al que pudimos llegar durante la investigación, y más puntualmente en el caso concreto es frente a las promesas de gobierno; no encontramos recurso jurídico que imponga al sub-sistema político $\circ$ al gobernante de turno cumplir estas, es más, ni siquiera cabe la posibilidad de la existencia de responsabilidad. Solo la consecuencia si prospera sería la revocatoria, y así se vuelve complejo el asunto, dado que en el siguiente periodo electoral donde se renovarán las estructuras de poder traerán como consecuencia el olvido de aquellas promesas inconclusas, y en lo referente a la sociedad, ésta entra en esos procesos de habituación, esto es, pasa todo por alto aquellas defraudaciones y continúan con su acostumbrada vida alejados de las cuestiones políticas. 
En lo que tiene que ver con los razonamientos de la Corte Constitucional frente a los temas de revocatoria del mandato, programa de gobierno, entendemos que aunque no existe una restricción para el fenómeno de la abstención en las votaciones, en lo tocante con la revocatoria cada ciudadano del territorio donde se vaya a presentar dicha convocatoria puede participar sin que exista cláusula restrictiva por parte de la Constitución o el Legislador. No obstante, la Corte Constitucional no se pronunció sobre la forma en que se evalúan los avances del programa de gobierno, las formas de medirlo, el control por parte de las veedurías y los límites de la oposición política. Frente a lo último no se encontró nada al respecto.

En lo referente al sub-sistema político los miembros pertenecientes a dicha estructura tienen bastante claro que durante la ejecución de su mandato cuando son elegidos, algo deben no saber u omitir y será ello la causa que lo lleve a valerse del sub-sistema jurídico para evadir su responsabilidad. Otro punto concierne a las posibles explicaciones que cada sub-sistema pueda dar de lo que conciben por democracia. Pero nuestro propósito no era generar convenciones sin respaldo; consideramos que lo realizado fue describir unas tendencias socio-político-jurídicas de la democracia.

Podemos concluir que la democracia surge como ficción y al mismo tiempo desaparece según pudimos ensayar en el estudio particular de caso comoquiera que, lo observado nos mostró cómo el alcalde de Bogotá valiéndose de herramientas jurídicas, evitó los pronunciamientos del llamado 
a elecciones para la revocatoria a los capitalinos. Los efectos políticos de sus promesas quedaron a un lado, prevaleciendo el sub-sistema del derecho más que la propia democracia opacándose nuevamente la figura políticoconstitucional de la revocatoria del mandato.

Otra alternativa que salta a la vista y, apoyados en los propios mecanismos de habituación y sensibilización §1, p. 84, encontramos cómo el ciudadano olvida muchas veces el por qué sufrago dejando el destino de sus vidas a otros actores políticos. En igual sentido, observamos una sociedad que se autoexcluye de las cuestiones políticas, cancelando así su propio derecho y dejando los "controles" en agentes políticos de oposición quienes como ya se describió actúan generando pactos secretos, es decir coaliciones públicas para obtener beneficios particulares o se valen de los éxitos y fracasos del gobierno de tuno para crear sus propias convenciones y así alcanzar el poder público ejecutivo pero a la postre sólo se reflejan actitudes particulares bastante alejadas del interés general.

La ambición entonces en esta investigación guarda armonía con la hipótesis planteada en el entendido de manifestar que a partir de la descripción de elementos constitutivos de la democracia y de las estructuras podemos sostener que no vivimos en democracia ni los sub-sistemas político o del derecho funcionan para que el ciudadano pueda manifestar su inconformidad por la manera en que se gobierna o no se atienden los postulados del interés general. 
Entonces, según las manifestaciones anteriores y las tendencias descritas, concluimos que el sub-sistema de la democracia surge según nuestro ejercicio y pautas metodológicas una vez los sub-sistemas de la política y del derecho, en conjunto con el sistema social coinciden en los periodos constitucionalmente estipulados para actualizar las estructuras de poder interpenetrándose entre sí. En otras palabras, dada la simultaneidad de eventos, surge la democracia y así mismo desaparece.

Así las cosas, aunque durante toda la investigación no-sólo nos apoyamos en otros saberes para intentar describir la tendencia democrática vigente, no se trató únicamente de criticar sino de justificar y complementar: (i) los elementos pre-constitutivos de la democracia, (ii) cómo entendemos surge la democracia como sub-sistema y, (iii) cuál es la finalidad de la democracia. De esta manera, con posturas doctrinarias diferentes, lo ya conocido como en la introducción revelamos qué era la democracia constituirá una diferente manera de comprender los asuntos democráticos vistos en su mayoría desde las posturas racionalistas o empiristas.

Con todo, la parte conceptual tratada en la primera parte, se espera pueda ser contrastada y afinada hasta donde el lenguaje-realidad lo permita a situaciones más heterogéneas o con mayor complejidad al caso examinado y, por consiguiente, llegar a ser comparado en contextos distintos a los estudiados 
para comprobar si a nivel práctico las razones que nos llevaron a formular los anteriores argumentos dependerá en la forma de concebir la democracia.

Bástenos aclarar que no se pretendía reclamar la totalidad del concepto democracia o dejar de lado lo que entienden el resto de los sujetos por misma, aunque como se podrá observar, sí insistiremos o reclamaremos cómo el subsistema político se vale del sub-sistema del derecho e incluso de la misma sociedad para lograr sus propios intereses por más que se identifiquen con la democracia.

Finalmente, si bien fue necesario valernos de un dato de realidad como fue el estudio del contenido de un programa de gobierno y el intento frustrado de revocatoria del mandato para reforzar nuestra parte teórica planteada en la primera parte, no quiere decir que con esto nos detengamos por lo asombroso de la realidad y quedemos en completa incertidumbre. Lo que se esperará de manera abstracta en futuras investigaciones será intentar extraer del propio sistema social o de los sub-sistemas político y del derecho, alternativas de solución a la complejidad descrita hasta el momento. 


\section{Biblografía}

Archila, M., Cote, J., Delgado, A., García, M., Madariaga, P., Pedraza, O. (2009). Una historia inconclusa: izquierdas políticas y sociales en Colombia Bogotá: Cinep.

Arendt, H. (1997). ¿Qué es la política?. Trad. Rosa Sala Carbo. Barcelona: Paidós.

Aguilera peña Vega, Renan. (1998) Ideal democrático y revuelta popular: Bogotá D.C.: CEREC.

Beck-Gernsheim, U.B. (2003). La individualización. Trad. Bernardo Moreno. Barcelona: Paidos.

Benda, J. (2008). La tración de los intelectuales. Trad. de R. Berraquero. Barcelona, España: Círculo de Lectores.

Bloom Harold. (2009). La ansiedad de la influencia- Trad. Javier Alcoriza, Madrit, España, Trotta.

Bobbio, N. (2013). El futuro de la democracia. Trad. de J. F. Fernandez. México: Fondo de Cultura Económica, S.A.

Bobbio, N. (1985). La crisis de la democracia. Trad. de J. Marfa. Barcelona, España: Ariel, S.A.

Bobbio, N. (2013). Democracia y secreto. Trad. De J.F Fernandez. México: Fondo de la Cultura Económica, S.A.

Bobbio, N. (1989). Estado, gobierno y sociedad. Trad. De J.F Fernandez. México: Fondo de la Cultura Económica, S.A.

Bobbio, N. (2013). Liberalismo y democracia. Trad. De J.F. Fernandez. Bogotá: Fondo de Cultura Económica.

Bourdieu, P. (2011) Intelectuales, política y poder. Trad. Alicia Gutiérrez. Buenos Aires, Argentina: Eudeba. 
Bunge, M. (2006). Epistemología. Mexico: Siglo XXI Editores.

Elias, Norbet. (2008). Sociología fundamental. Trad. Gustavo Muñoz. Barcelona: Gedisa.

Galli, Carlo (2013). El malestar de la democracia. Trad. de María Julia De Ruschi. Buenos Aires: Fondo de Cultura Económica de Argentina.

García, Néstor (2001) Culturas híbridas: estrategias para entrar y salir de la modernidad. Buenos Aires. Paidós.

García, Néstor (1984) Cultura y organización popular: Gramsci con Bourdieu en Cuadernos Políticos, número 38, ediciones era méxico, D.F. enero-marzo 1984, pp.75-82.

Heller, A. (1996). Una revisión de la teoría de las necesidades. Trad. de Á. R. Rodríguez. Barcelona, España: Paidós.

Hobbes, T. (1651). Leviatan. Trad. Manuel Sánchez Sarto. Buenos Aires: Fondo de Cultura Económica de Argentina.

Honneth, A. (2005). Reificación. Argentina: Katz.

Honneth, A. (2011). La sociedad del desprecio. Trad. de F. J. Herzog. Madrid: Trotta.

Kandel, E. R. (2008). En busca de la memoria. Trad. Elena Marengo. Argentina: Katz.

Luhmann, N. (1980). ¿Cómo es posible el orden social?. Trad. Pedro Morande Court. Mexico: Herder.

Luhmann, N. (1998). Sistemas sociales: lineamientos para una teoría general.Trad. S. Pappe y B. Erker. Barcelona: Anthropos.

Luhmann, N. (2005). El derecho de la sociedad. Trad. de Javier Torres Nafarrate. México: Herder.

Luhmann, N. (2005). Organización y desición. Autopoiesis, acción y entendimiento comunicativo. Trad. de D. R. Mansilla. Barcelona, España: Anthropos. 
Luhmann, N. (2005). Poder. Trad. de la edición inglesa de Jhon Wilwy \& Sons (Chichester/Nueva York/Brisbane/Toronto. Barcelona, España: Antrhopos.

Moreno, A y Ramírez, J (2006). Pierre Bourdieu. Introducción elemental. Bogotá. Panamericana Editorial.

Moreno, A y Ramírez, J (2011). Sociología del campo jurídico en Colombia: Relaciones y perspectivas. Bogotá. Universidad Santo Tomás Editorial.

Morin, E. (2008). Introducción al pensamiento complejo. Trad. Marcelo Pakman. Barcelona: Gedisa.

Nohlen, D. (2011). La democracia, instituciones, conceptos y contexto. México: Instituto de Investigaciones Jurídicas de la Universidad Nacional Autónoma de México. Serie Doctrina Jurídica №591.

O’Donnell, G. (2009). El Estado burocrático autoritario. Buenos Aires: Prometeo.

Ocampo, J., Gomez, A., Diaz, Z., Ocampo, J., Orjuela, L., Sanchez, R., Gonzalez, F., Archila, M., Gonzalez, J. (2008). Historia de las ideas políticas en Colombia. Bogotá: Taurus.

Perez, H. (1989). Proceso del bipartidismo Colombiano. Bogotá: Universidad Nacional de Colombia.

Pinker, S. (2012). Los ángeles que llevamos dentro. Trad. Joan Soler Chic. Madrid: Paidós.

Poper, K. (1994). Búsqueda sin término. Trad. de C.G. Trevijano. Madrid, España: Tecnos.

Reale, G., \& Antiseri, D. (1983). Historia del pensamiento filosófico y científico. Trad. Juan Andrés Iglesias. Barcelona: Herder.

Rosanvallon Pierre, (2009). La legitimidad Democrática. Trad. Herber Cardoso Buenos Aires: Manantial.

Ross, A. (1989). ¿Por qué democracia? Trad. de R. J. Vernengo. Madrid, España: Centro de Estudios Constitucionales. 
Ross, A. (2007). Teoría de las fuentes del derecho. Trad. Madrid: Centro de Estudios Políticos y Constitucionales.

Santos, B. d. (2004). Reinventar la democracia, reinventar el Estado. Trad. de D. P. Cerezales. Quito: Abya-Yala.

Santos, B. d. (2001). El caleidoscopio de las justicias en Colombia. Bogotá: Colciencias - Instituto Colombiano de Antropología e Historia - Universidad de Coimbra CES - Universidad de los Andes - Universidad Nacional de ColombiaSiglo del Hombre Editores.

Sartori, G. (2007). Teoría de la democracia, el debate contemporáneo. Trad. Santiago Sánchez González. Madrid: Alianza Universidad.

Sartori, G. (2010). La Política -Lógica y método en las ciencias sociales-. $3^{\text {á }}$ ed. Trad. de L. Marcos. México: Fondo de Cultura Económica.

Sartori, G. (2011). Cómo hacer ciencia política -lógica método y lenguaje en las ciencias sociales-. Trad. de M. Á. Azúa. Madrid, España: Santillana Ediciones.

Touraine, A. (2006). ¿Qué es la democracia? Trad. de H. Pons. México: Fondo de Cultura Económica.

Tugendhat, E. (1997). Lecciones de ética. Trad. Luis Román Rabanaque. Barcelona: Gedisa.

Walzer, M. (2008). La revolución de los santos. Estudio sobre los orígenes de la política radical. Trad. Silvia Villegas. Buenos Aires: Katz.

Weber, M. (1995). El político y el científico. Trad. De F.R Llorente. Barcelona: Altaya. 
NORMATIVIDAD CITADA

Constitución Política de 1991.

Ley 131 de 1994.

Ley 134 de 1994.

Ley 741 de 2002 .

Decreto 895 de 2000.

Registraduría Nacional del Estado Civil:

- Resolución 1056 de 2004.

- Resolución 023 de 2005.

- Circular 052 de 2005.

- Circular 174 de 2012.

\section{JURISPRUDENCIA CITADA}

Corte Constitucional:

- Sentencia C-011 de 1994. M.P.: Alejandro Martínez Caballero.

- Sentencia C-180 de 1994. M.P.: Hernando Herrera Vergara.

- Sentencia C-538 de 1995. M.P.: Fabio Morón Díaz.

- Sentencia C-1258 de 2001. M.P.: Jaime Córdoba Triviño.

- Sentencia C-179 de 2002. M.P.: Marco Gerardo Monroy Cabra.

Consejo Nacional Electoral (Rad. 1668 de 2009). C.P.: Ciro Muñoz Oñate 
Consejo Nacional Electoral (Rad. 1315 de 2005).

Tribunal Administrativo de Cundinamarca. Sección Tercera. Subsección A, Sentencia de Tutela 2013-796-00. M.P.: Alfonso Sarmiento Castro.

\section{PÁGINAS WeB CITADAS}

http://www.alcaldiabogota.gov.co/sisjur/normas/verNormaPDF?i=45478 http://www.registraduria.gov.co/IMG/pdf/acta_entrega_firmas_18_abril.pdf http://www.registraduria.gov.co/IMG/pdf/certificacion_reg_distritales_19_abril. pdf http://www.registraduria.gov.co/IMG/pdf/FLAVIO_AUGUSTO_RODRIGUEZO 001.pdf http://www.registraduria.gov.co/descargar/revocatoria-alcaldepetro170513.pdf http://www.registraduria.gov.co/descargar/resolucion_766_de_2013.pdf http://www.registraduria.gov.co/IMG/pdf/SOLICITUD_Y_RESPUESTA_EXPE RTOS_INTERNACIONALES.pdf

http://www.registraduria.gov.co/IMG/pdf/tutela_petro.pdf http://www.registraduria.gov.co/IMG/pdf/AUTO_CUMPLIMIENTO_TUTELA_ REVOCATORIA_GUSTAVO_PETRO.pdf http://www.registraduria.gov.co/IMG/pdf/impugnacion_fallo_tutela.pdf http://www.registraduria.gov.co/IMG/pdf/0001INF_DISTRITAL.pdf 
http://www.registraduria.gov.co/IMG/pdf/Resolucion_1019_de_2013_2.pdf http://www.registraduria.gov.co/IMG/pdf/RESOLUCION_008_DE_2014.pdf http://www.registraduria.gov.co/IMG/pdf/Notificacion_personal_res_1019_de_ 2013.pdf

http://www.registraduria.gov.co/IMG/pdf/notificacion-res1209-2013.pdf http://www.registraduria.gov.co/IMG/pdf/auto-q-avoca-conc.pdf http://www.registraduria.gov.co/IMG/pdf/Resolucion_13806_2013.pdf http://www.registraduria.gov.co/IMG/pdf/res-0183-2014.pdf http://www.registraduria.gov.co/IMG/pdf/Res_340_2014_terminacion_revocat oria_petro.pdf http://www.colombianistas.org/Portals/0/Congresos/Documentos/CongresoXI V/PonenciasPDF/ayala_diago_ponencia.pdf http://www.banrepcultural.org/node/32717 http://www.banrepcultural.org/blaavirtual/ayudadetareas/poli/frentenacional.ht $\mathrm{m}$

http://www.moir.org.co/FRANCISCO-MOSQUERA-FUE-UN.html http://www.semana.com/nacion/articulo/demanda-de-alcalde-petro-en-lacomision-interamericana-de-derechos-humanos/362681-3 http://www.semana.com/nacion/articulo/cidh-caso-petro-venezuela-comotemas-clave/381492-3 http://www.banrepcultural.org/blaavirtual/ciencias/sena/periodismo/cartillacinc o/carcin5.htm 